\title{
GROUNDWATER MONITORING IN THE SAVANNAH RIVER PLANT LOW LEVEL WASTE BURIAL GROUND (U)
}

by WSRC Contact - W. H. Cartton

Westinghouse Savannah River Company

Savannah River Site

Aiken, South Carolina 29808

J.P. Ryan

This paper was prepared in connection with work done under Contract No. DE-AC09-89SR18035 with the U. S. Department of Energy. By acceptance of this paper, the publisher and/or recipient acknowledges the U.S. Government's right to retain a nonexclusive, royalty-free license in and to any copyright covering this paper, along with the right to reproduce and to authorize others to reproduce all or part of the copyrighted paper. 
Groundwater Monitoring in the Savannah River Plant Low Level waste Burial Ground:

A Summary and Interpretation of the Analytical Data

By: J. P. Ryan

February 20, 1983

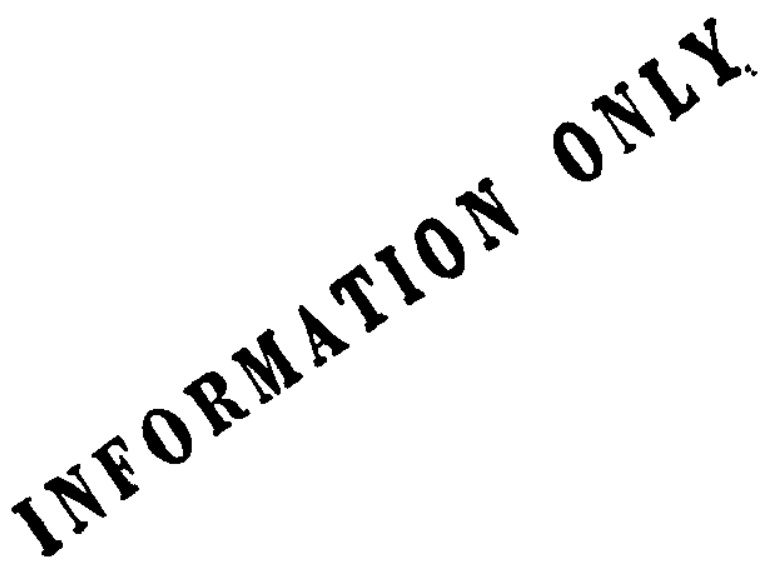


TABLE OF CONTENTS

\begin{tabular}{|c|c|c|c|}
\hline & & & $\begin{array}{l}329= \\
\text { So. }\end{array}$ \\
\hline I & Summary & & 1 \\
\hline I I & Introduction & $\begin{array}{l}\text { The Burial Ground } \\
\text { Groundwater Monitoring }\end{array}$ & $\begin{array}{l}2 \\
3\end{array}$ \\
\hline III & Discussion & & 3 \\
\hline IV & Operations History & $\begin{array}{l}\text { Radioactive "Normal" Wells } \\
\text { Solvent Spill } \\
\text { Equipment Decontamination Area }\end{array}$ & $\begin{array}{r}9 \\
9 \\
11\end{array}$ \\
\hline $\mathrm{V}$ & Radiochemical Analyse & $\begin{array}{l}\text { Gross Alpha, Non-Volatile Beta-Gamma } \\
\text { In Situ Gamma Scan } \\
\text { Low-Level High-Resolution Counting } \\
\text { Methods and Sample Praparation } \\
\text { Natural Radioactivity } \\
\text { Results }\end{array}$ & $\begin{array}{l}13 \\
13 \\
13 \\
14 \\
14 \\
15 \\
16\end{array}$ \\
\hline VI & Chemical Analysis of & $\begin{array}{l}\text { 643-G Groundwater } \\
\text { Monitoring Well Data Treatment } \\
\text { General Parameters } \\
\text { pH } \\
\text { Oxidation-Reduction Potential } \\
\text { (EH) } \\
\text { Dissolved oxygen (DO) } \\
\text { Conductivity (COND) } \\
\text { Complexing Anions (and Carbon) } \\
\text { Total Inorganic Carbon (TIC) } \\
\text { Total Organic Carbon (TOC) } \\
\text { Fluoride } \\
\text { Chloride } \\
\text { Nitrate } \\
\text { Sulfate } \\
\text { Phosphate } \\
\text { Silicate } \\
\text { Competing Cations } \\
\text { Sodium } \\
\text { Potassium } \\
\text { Calcium } \\
\text { Barium, Strontium } \\
\text { Iron } \\
\text { Magnesium }\end{array}$ & $\begin{array}{l}16 \\
17 \\
18 \\
18 \\
23 \\
25 \\
26 \\
26 \\
26 \\
32 \\
33 \\
38 \\
39 \\
39 \\
40 \\
43 \\
44 \\
44 \\
45 \\
45 \\
46 \\
46 \\
47\end{array}$ \\
\hline
\end{tabular}


VII Conclusions and Recommendetions 47

Burial Ground Performance 47 Long-Term Radionuclide Migration from waste Trenches 43 $\begin{array}{ll}\text { Recommendations } & 49\end{array}$

VIII Appendices

Appendix A - Analytical Methods
Appendix B - Radiochemical Data
Appendix C - Chemical Data
Appendix D - Statistical Sumnary of $643-$ G Groundwater
Appendix E - A A Summary of the Chemically Anomalous
Appendix F - Radioactive Wells with "Normal"
Chemistry

IX References 
DPST $-83-209$

\author{
GROUNDWATER MONITORING IN THE SAVANNAH RIVER PLANT \\ LOW LEVEL WASTE BURIAL GROUND: \\ A SUMMARY AND INTERPRETATION OF THE ANALYTICAL DATA
}

\title{
SUMMARY
}

This document describes chemical mechanisms that may affect trace-level radionuclide migration through acidic sandy clay soils in a humid environment, and summarizes the extensive chemical and radiochemical analyses of the groundwater directly below the SRP Low-Level Waste ( $L L W$ ) Burial Ground (643-G). Anomalies were identified in the chemistry of individual wells which appear to be related to small amounts of $E$ ission product activity that have reached the water table. The chemical properties which were statistically related to trace level transport of Cs-137 and Sr-90 were iron, potassium, sodium and calcium. Concentrations on the order of $100 \mathrm{ppm}$ appear sufficient to affect nuclide migration.

Several complexation mechanisms for plutonium migration were investigated, but most of these were shown to be incapable of mobilizing more than trace quantities of plutonium. The parameters of greatest importance were oxidation - reduction potential, pH, dissolved organic carbon, phosphate and carbonate. Of these, organic and phosphate complexation had the greatest potential for mobilizing plutonium in the SRP groundwater. In the absence of such complexants, plutonium would be essentially immobile in the soil/water system of the SRP burial ground. 
E. L. ALBENESIUS -2- DPST-83-209

A thorough radiochemical analysis was also performed on all wells that had a history of alpha and/or non-volatile beta-gamma contamination, as determined by routine monitoring. Additional wells wera selected for radioanalysis on che basis of a survey that included in-situ gamma scans of the monitoring wells.l of the twenty wells that were tested, only two contained alpha or fission product activity above EPA standards for public water supplies. Across the burial ground, gross levels of activity in the groundwater have actually decreased through dilution and dispersion over the past five years.

In addition to decreases in gross activity, there is evidence that the rate of radionuclide migration has decreased over the past few years, especially in the older, eastern section of the SRP burial ground. This observation is attributed to reduced concentration, in the groundwater, of materials from the buried waste that could mobilize radionuclides. Transport velocities will gradually decrease as the trench leachate becomes more dilute. Plutonium-239, which is presently detectable only at trace levels, should follow this general trend, becoming fixed in the soil of the waste trenches.

\section{INTRODUCTION}

\section{The LLW Burial Ground}

The solid waste disposal area that will be discussed in this report is the 643-G Low Level waste (LLW) Burial Ground. Located between the two separations areas at the savannah River Plant, this area received solid wastes from Plant and Laboratory facilities from 1954 through 1971.2 Liquid wastes were not buried there, but some contaminated organic solvents were stored in tanks at the site, and large volumes of that solvent were burned in open pans in shallow pits during the first fifteen years of operation. 3

Major sources of activity include both fission and activation products on discarded process equipment and reactor hardware. Plutonium-contaminated waste from various locations was also received routinely.

Waste materials were placed in categories for disposal with "low-level" (low beta-gamma or suspect alpha) waste going in some trenches, "high activity" (high gamma activity solids) waste in others. plutonium or "alpha" waste was disposed of in separate trenches. After 1965 most of this category was buried retrievably in concrete containers and since 1974 all $\mathrm{Pu}$ waste $>10 \mathrm{nCi} / \mathrm{g}$ has been stored on pads on the surface. 2 
E. L. ALBENESIUS -3- DPST-83-209

Additional details of burial ground operations at SRP can be found in the Final Environmental Impact Statement. 4

Groundwater Monitoring

The groundwater below the $(643-G)$ Low Level waste Burial Ground has been monitored for radionuclide contamination since 1956. Although that site stopped receiving waste in 1971, SRP continues to monitor the groundwater there for radionuclide transport. 4 There are now 63 accessable groundwater monitoring wells within the burial ground perimeter. These are laid out on a 200-foot grid with 20-foot well screens centered at the water table, approximately 40 feet below grade (Figures 1,2 ). Since installation in 1973, only 12 of these wells have contained more than background levels of non-volatile beta-gamma or alpha emitters (Figure 3 ). 5-8

A thorough analysis of the groundwater monitoring wells was performed, from July, 1980 through July, 1982 , to establish "baseline" chemical conditions, and to identify some of the mechanisms by which traces of radionuclides are mobilized in the subterranean environment. With that data, reported here, it will be possible to measure changes in water quality caused by the presence of waste material in the burial trenches. Radionuclide migration velocities will also be more predictable now that most of the water quality parameters which affect migration have been measured. Finally, the combination of better transport information and actual long-term radiochemical information will be useful for calibrating the existing radionuclide transport models.

\section{DISCUSSION}

Solubility, Ion Exchange and Complex Formation as Factors Affecting Migration

Radionuclide migration and the spread of conventional chemical pollutants are closely linked in a low-level waste burial ground. Many common chemicals, including simple salts and possibly even the degradation products of standard packaging materials, can affect the mobility of radionuclides.9-15 These effects can be either positive or negative, and their overall impact on the efficiency of radionuclide containment at a low-level waste burial site is determined by the average of the effects in each isolated system (trench location) within the site. Vertical transport through the unsaturated zone to the groundwater is specifically defined for each trench by its contents. Lateral transport in the groundwater is then determined by the soil and water chemistry of the total system. 


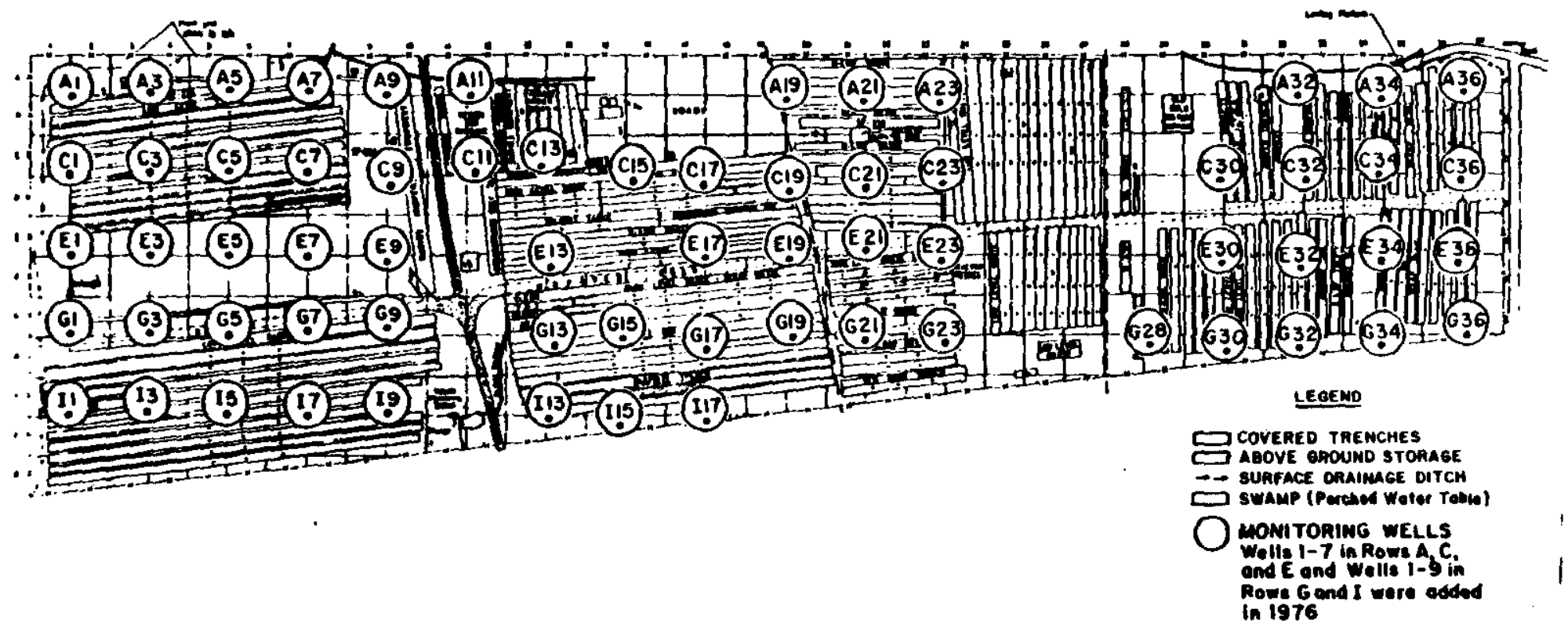

We11s A-7 and A-9 were temporarily out of service and well I-3 was dry during the chemical analysis survey. Well E-15 (between E-13 and E-17) was drilled 1n 1977, and went dxy in 1980. 

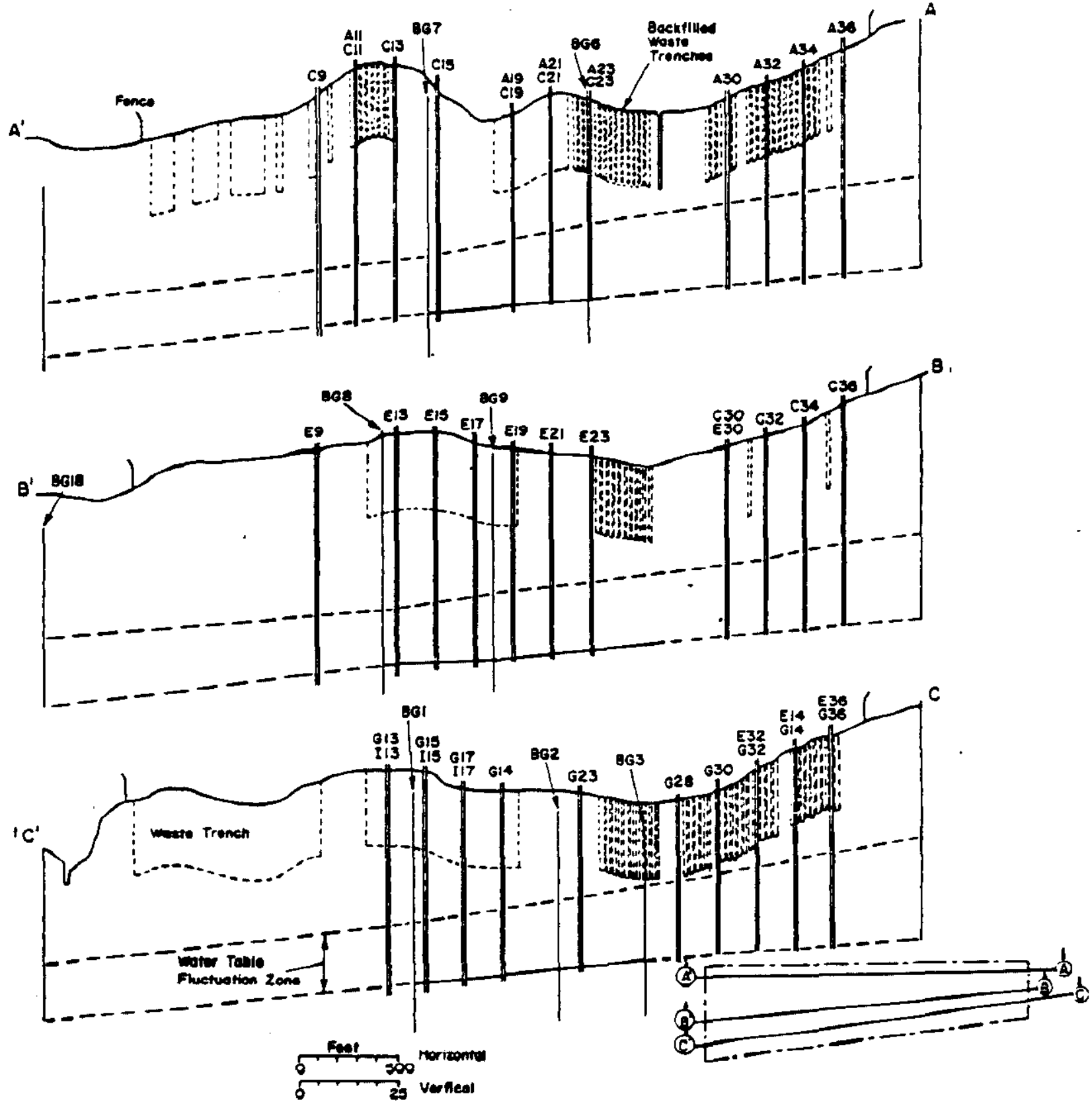

FIGURE 2 - Burial Ground Crose Sections Showing Details of Water Table Well Construction (Ref 8). 
643-G WeIIs That Contain Measurable Radioactivity

年

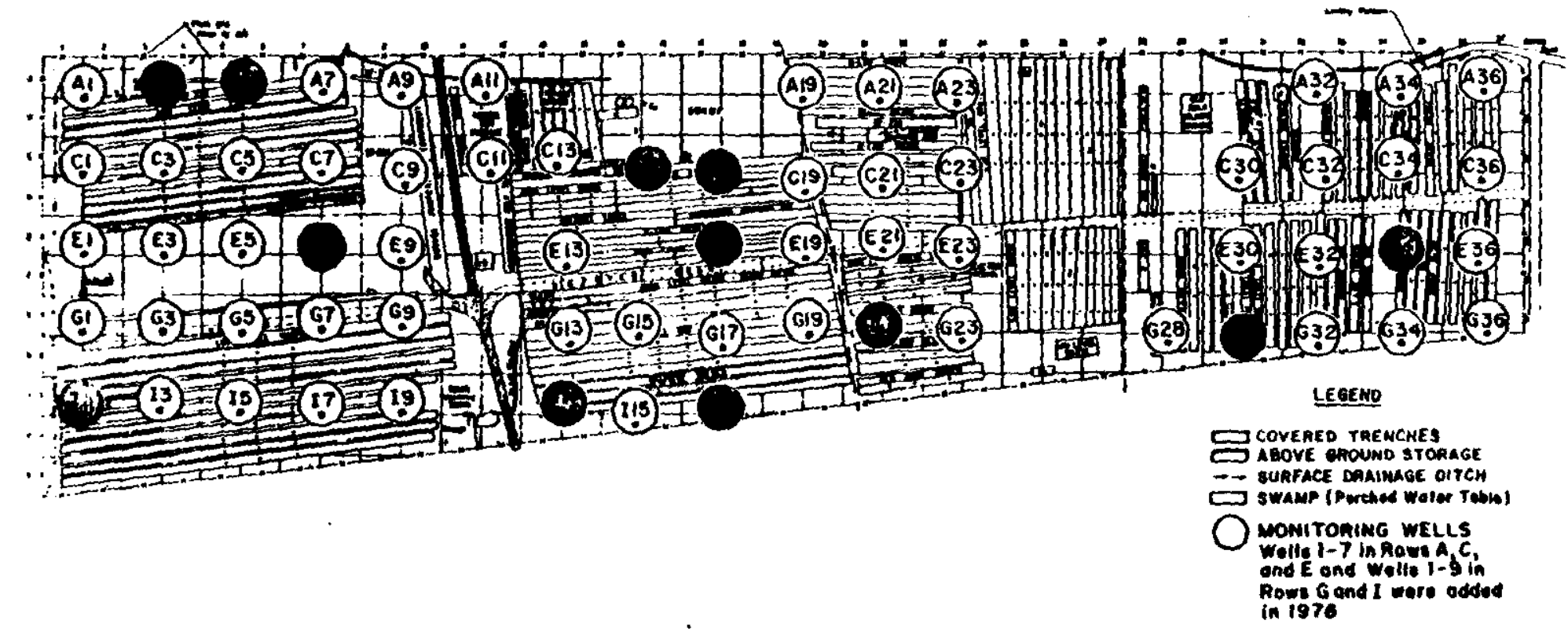

FIGURE 3. Filled in circles are wells where measured radioactivicy has exceeded background in past routine monltoring surveys from 1973 to 1976. Tritsum data is not included here (see Ref 8). 
The solubility of a radionuclide is determined by tie chemistry of the solution in which it is dissolved. The presence of certain counterions may tend to limit or enhance that solubility, depending on the nature of theis interaction. For example, $\mathrm{Sr}-90$ is virtually insoluble in alkaline carbcnate. 15 on the other hand, although most plutonium compounds are normally extremely insoluble in solutions of low ionic strength, one of the most important factors in ultra trace level plutonium migration ma: be its tendency to form soluble carbonate complexes. 18 Chemical factors that can also affect the solubility of a radionuclide include the oxidation potential, $\mathrm{pH}$, and ionic strength.

Although they are certainly related, the solubility of a radionuclide in the groundwater should not be equated with its mobility in the groundwater system. Many ions that are quite soluble move very little in the natural system because of their interaction with soil (e.g., cesium).13,17,19 The most important of these interactions is ion exchange adsorption by the soil.

The efficiency of radionuclide adsorption and retention by soil depends on the soil cation exchange capacity, its structure, and on the water chemistry. For example, the same stable complexes that improve solubility also tend not to be adsorbed by ion exchange sites on soils.9-11 competitive ion exchange can also occur, where high concentrations of other salts "swamp out" $r$ adionuclides in the competition for ion exchange sites on the soil, thereby causing them to stay in solution and move with the groundwater flow. The type of ions in solution is also important, because some are more efficiently retained by soil, and therefore, compete more effectively for exchange sițes.

Around a typical low-level waste burial ground, both the solubility and the ion exchange behavior of radionuclides are influenced by complexation. Anionic and soluble neutral complexes are sorbed very poorly by most soils.ll This includes the strong chelation complexes formed by some organic materials (e. g., EDTA) as well as the more loosely associated complexes that are formed with some common anions (e.g. $\mathrm{Cl}^{-}$and $\mathrm{HPO}_{4}^{-}$) and many common

organic species (e. g. organic esters, acids, ketones and aldehydes. Generally, the stronger the complex, the greater the mobility that will be imparted to the migrating radionuclide. Very weak compexes, and those which include multiple monovalent anions, usually a sect ion mobility only at high ligand concentrations. This tends to limit the effects of such weak complexes to a region within of very near the trenches, making them relatively unimporta=ニ. 
Anionic radionuclides (e.g. I-129, Tc-99) are inherentIy mobile and are not greatly affected by cation excliange or ligand complexation. However, the oxidation-reduation potentiai of the system can have an important impact on tueir mijration $y=\$ 0: 2=\%$. For instance, the oxidized form of Tc-99 is mobile, but the ceduced form is not. 20 owing to the reactivity of $I_{2}$, just the opposite may be true for I-129. Often, the dissolved oxygen content of the water (DO) is the preferred indicator of the oxidation potential of natural water systems, because measured oxidation-reduction potentials tend to be erratic in dilute solutions. 21 However, direct measurement with a platinum electrode may still be the best indicator of an unusually oxidizing or reducing condition.

Possibly the most important parameter for predicting if mobilizing mechanisms will be operative is the pH of the solution. Most of the mechanisms, including complex Eormation, oxidation-reduction, and hydrolysis, are pH-dependent. Low oH (acidic) systems favor radionuclide mobility by improving the solubility of metals, by competing for ion exchange sites on the soil, and by dissolving potential adsorption sites. More alkaline conditions, in the absence of complexing anions, generally tend to immobilize radionuclides. Clay soils become less permeable, especially in the presence of sodium. In addition, the formation of metal hydroxides and carbonates provides more potential adsorption sites for cationic radionuclides, and the solubilities of many radionuclides are substantially reduced by hydrolysis. However, anionic carbonate and hydroxycarbonate species and other complexes may be formed under alkaline conditions, thus mobilizing radionuclides such as plutonium and $c_{0}-60$.

Summarizing, the water quality parameters that have the greatest impact upon radionuclide migration include ph, the concentration of iron and other competitive cations, total organic carbon, oxidation-reduction potential, dissolved oxygen, conductivity, and complexing anions. The mechanisms most likely to enhance radionuclide mobility are non-exchangeable complex formation, and competitive cation exchange.

This information will be presented for each of the groundwater (GW) monitoring wells in the chemistry section of this report. The theoretical impact of the normal and extreme values for each parameter will then be discussed and compared to the radiochemical summary of the $G W$ wells. The following section provides a brief account of pertinent burial ground operations history - relating events that are responsible for appearance of radiochemical contamination at the water table in two locations. 


\section{ORERATIONS HISTORY}

"Normal" Wells Containing Incisenzai Contamizejicn

In addition to long-term radionuclide transport from the waste disposal trenches, incidental contamination from burial ground operations is also detectable in some of the groundwater monitoring wells. This is why a few of the monitoring wells in the burial ground contained traces of plutonium, even though their chemistry was apparently normal. These can be divided into two categories, the "solvent spill wells" and the wells affected by equioment decontamination operations. These will be discussed separately, and will be referred to throughout this report.

\section{Solvent Spill}

In 1971, approximately 200 gallons of contaminated TBP-kerosene was accidentally released to the groundwater, when a dry monitoring well was mistaken for a solvent storage tank header. This accident took place near well $c-17$, but when the solvent reached the groundwater it spread over a considerable distance. 22 A series of cores were taken to the depth of the water table to determine the extent of the contamination (see Figure 4).

Approximately 250,000 gallons of water were pumped from well C-17 to measure the extent of the radioactivity thera. 23 The water was discharged to the H-Area seepage basin. Small amounts of activity have remained in the area, and the contamination levels in the surrounding monitoring wells have tended to fluctuate with the height of the water table. This is believed to be due to an extremely disperse film of contaminated solvent that essentially floated on the water table. Some of that solvent probably remained on the soil when periods of drought caused the water table to recede. As the water table returns to higher levels in wet years. the groundwater tends to pick up material that was sorbed on soil when the water level declined. 5-8

The wells that were originally affected by the solvent release were $C-15, C-17, E-13, E-17, E-19, G-13, G-15$, $G-17$, G-19. I-7, I-9, I-13, I-15, and I-17. So $f$ ar, of the wells analyzed by low level alpha pulse height, $C-17, E-13$ and $E-17$ are below $1 \mathrm{pCi} / \mathrm{L}$. Well E-17 still contains the Eission and activation products $\mathrm{Cs}-137$ and Co-60; but these are now at levels considerably less than tbe drinking water standards, which are currently 200 and $100 \mathrm{pCi} / \mathrm{L}$, respectivelY. 24

F-ature low-level analyses should be able to establish whether the plator (solvent sp三ll) as the rest. However, preliminary isotope ratio 


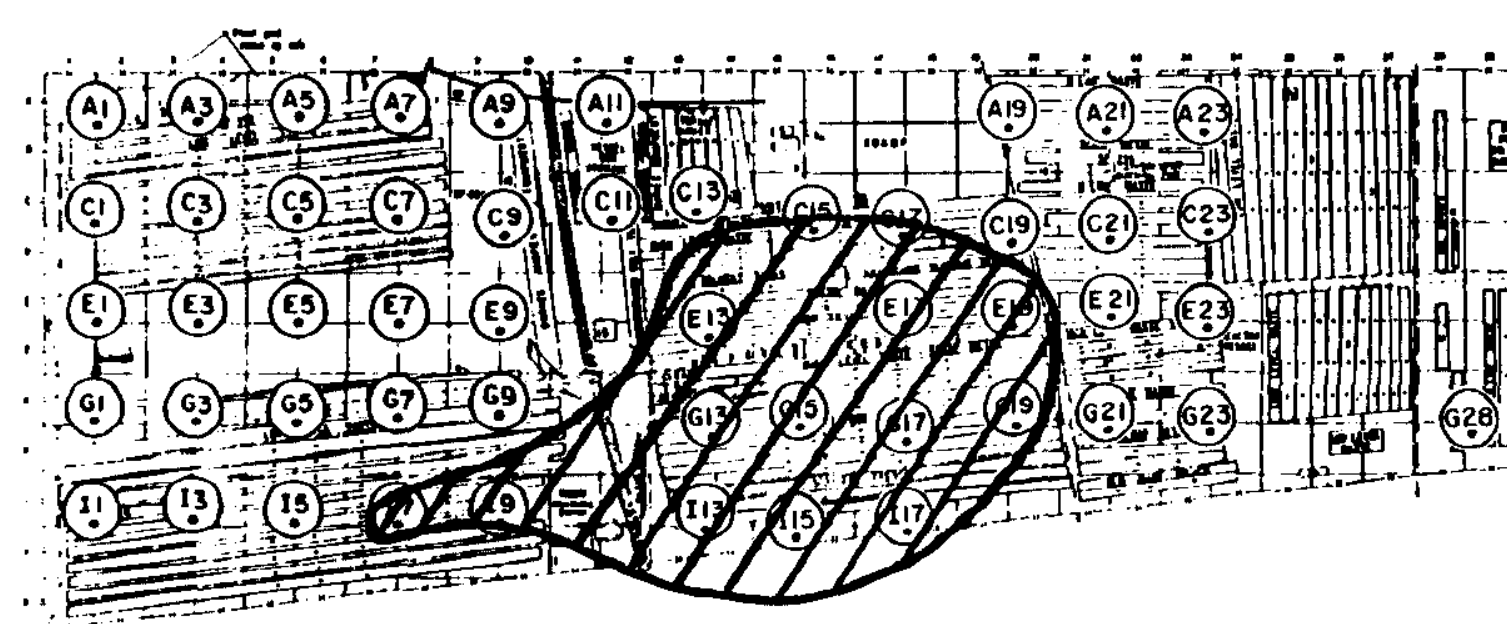

$$
\begin{aligned}
& \rightarrow \text { SURFACE DRAIMAGe DITCH }
\end{aligned}
$$

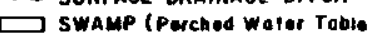$$
\text { COVEAED TAENCHES }
$$

Figure 4. Area of 1971 contaminated solvent spill. 
measurements indicate that $i t i s$ not. The rate of dissipation of plutonilum will also be of interest as the i3js cortaninated wells are monitored.

\section{Equipment Decontamination Area}

The activity in Wells $A-3, C-1$ and $C-3$ may have been present before waste was even buried in that region. sarly in the operations history of the 643-G burial ground, the northrest corner was used as a storage area for burial ground equipment. 25 A decontamination station was operated to the east of that storage area, between and just north of the $A-3$ and $A-5$ monitoring wells (see Figure 5) which were installed much later.

Complexing agents such as EDTA were apparently used in addition to phosphate detergents to remove contamination from the metal equipment. These agents have apparently mobilized traces of plutonium and $S r-90$ to the extent that they are now detectable at the water table, which is forty feet below grade. The predicted contamination area drawn in Figure 5 is based on the water table contour of that area.

Usually it is possible to judge whether a single source is responsible for contamination at several locations by the reproducibility of the isotopic ratios. However, since many sources of activity were present in the form of different pieces of burial ground equipment, each could have a different isotopic ratio. The monitoring wells are not all the same distance from the decontamination station. They would, therefore, not be expected to have the same isotopic ratios of plutonium, because the source ratio would have varied with time. Furthermore, the decontamination area is probably too large compared to the migration path length to be considered a point source, so the material that cane from one side would not necessarily be the same as material from the other.

A major point in support of this explanation is that there is Iittle or no other plutonium in that area of the burial ground, regardless of the transport mechanisms involved. There are two trench wells along the A-Line that have been known to contain water. These (TW-7 and $T W-9$ ) are sampled at regular intervals whenever water is present, and gross alpha/non-volatile beta-gamma measurements are made. A low-level pulse height analysis was also performed on the closest trench well to A-3 (TW-9). Pu-238 was detectable at only $7 \mathrm{pCi} / \mathrm{L}$, which is approximately the highest a lpha concentration ever observed in $T W-7$ and 508 of the maximum observed in nine years of monitoring $T W-9$. If such low concentrations are found in the nearest trenches, it isn't likely that even higher levels could be migrating from them to the groundwater. (Furthermore, the burial ground records do not show any likely source of plutonium in that general area.) 


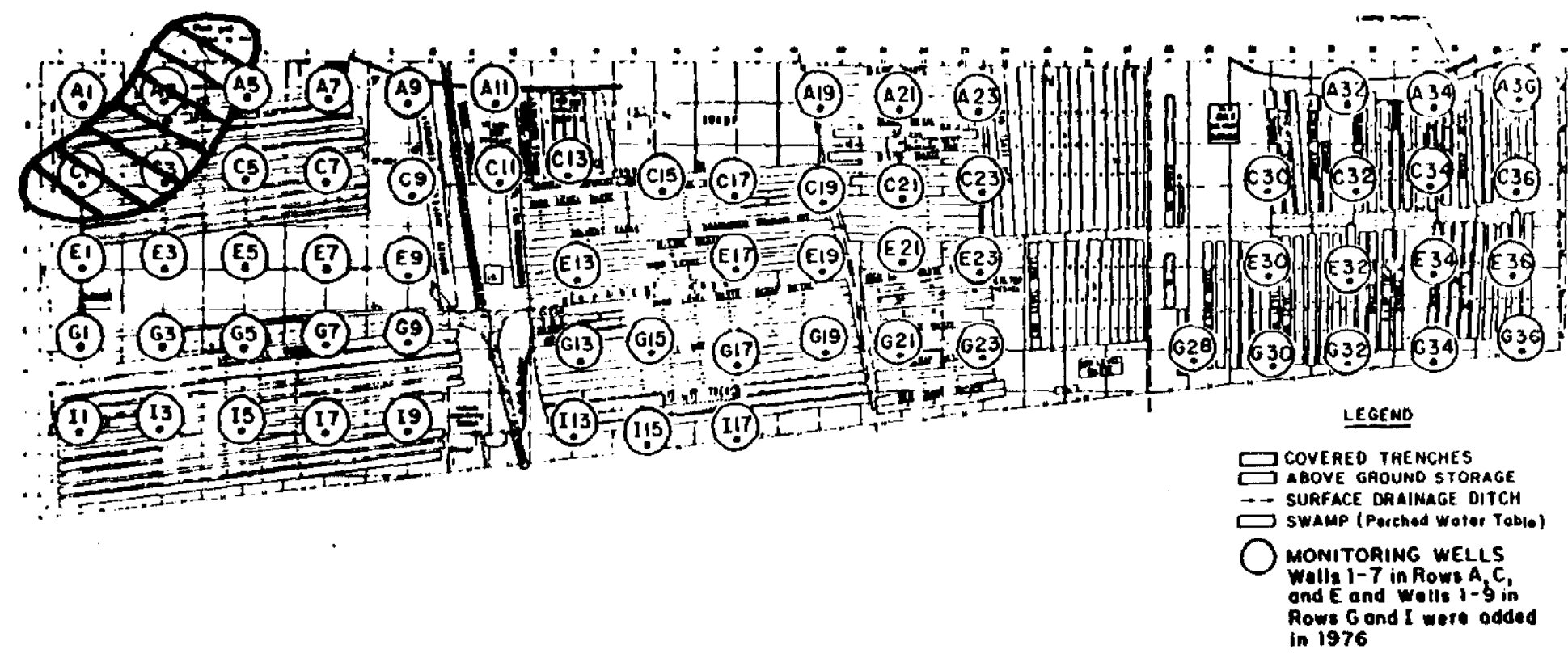

Figure 5. Groundwater af fected by equipment decontamination solvents (postulated). 
If the conclusions concerning the decontamination solvents are true, it should be possible to locate the old decontamination station and obtain a soil core in that area. To determine whethar tire contanination level in wells $A-3, C-1$ and $C-3$ will go down or up in the near term, one would have to know moce about the source. But since the complexants are probably all but gone now, the migration behavior of the radionuclides should be similar to what will occur elsewhere in the burial ground many years from now. The activity levels in the groundwater will decline.

\section{RADIOCHEMICAL ANALYSES}

\section{Gross Alpha, Non-Volatile Beta-Gamma}

Gross alpha and non-volatile beta-gamma measurements have been made of the 643-G grid wells on a bimonthly basis since they were first installed.5-8 The 43 wells in the east and central sections have been in place since 1973. The wells in the western section (Al-9, C1-7, $11-7$, G1-9, and Il-9) were added in 1976. Nominal background levels for these measurements with the equipment and methods used are $3 \mathrm{pCi} / \mathrm{L}$ gross alpha, and $50 \mathrm{pCi} / \mathrm{L}$ non-volatile beta-gamma. Wells that contained more than these levels of activity as of 1980 were considered contaminated, and samples from each were taken for Sr-90 determinations and low-level counting by gamma spectrometry and alpha pulse height. with the exception of Nell E-15, which was temporarily inaccessable for sampling, the low-level analyses of these wells are listed in Table Bl (Appendix B) along with those of the wells chosen for analysis based on in-situ gamma spectrometric scans, 26 as described below.

Natural activities were low in the gross alpha - nonvolatile beta-gamma measurements since the samples were allowad to settle for at least 48 hours before aliquots were taken for analysis. This procedure tends to minimize the activity associated with particles suspended in solution in much the same manner as coarse filtration, but with less handling. However, there is normally an additional reduction of activity in some wells via coprecipitation of certain radioisotopes, as Fe(II) slowly oxidizes to Fe(III) and precipitates from many samples. There is evidence that this loss of activity occurs in samples Erom Well G-21, which contains roughly 110 ppm of iron. Routine non-volatile beta-gamma measurements detected $219 \mathrm{pCi} / \mathrm{L}$ of activity in 198016 samples, bimonthly). However, $1600 \mathrm{pCi} / \mathrm{L}$ of strontium was detected in that well in the same year by more exact methods. 27

\section{In Situ Gamma Scan}

In 1980-81, W. W. Bowman performed low-level, high resolution gamma scans on each of the monitoring wells in the 643-G burial ground. This was accomplished by lowering an intrinsic ithium-germanium crystal detector into each well and recording the 
output as a function of depth. Early in the study, several welis wiare found with very small areas of Cs-137 and/or Co-60 contamination lccated balow the depth of the tranch cottons. 26 incer ra-scanniag these wells it vas decermined that chese locations probably represented contamination that was transferred when the monitoring wells were drilled. The possible exception was Well A-3, which seemed to contain small amounts of Cs-137.

This study was used as additional input for the selection of wells that could be contaminated at very low levels. All of the wells that gave any indication of contamination at depth via the in-situ scans 26 were sampled and analyzed by the low-level methods described below. Low-level counting results are recorded in Table Bl, Appendix B.

\section{Low-Level figh Resolution Counting}

\section{Methods and Sample Preparation}

In spite of the apparent sensitivity of the gross alpha and non-volatile beta-gamma methods, low-level high-resolution counting is indispensable to the investigation of a low-level waste burial site. The counting and sample preparation methods that were applied to routine monitoring (gross alpha and non-volatile beta-gamma) at SRP were designed to handle large sample loads and to detect gross changes in activity. Variations in sensitivity caused by sample chemistry [e.g. coprecipitation of radionuclides with Fe(III)] were not considered, and all but the major differences in the natural activity background were necessarily ignored. The resolution of decay energy was also extremely poor. As a result, significant qualitative information was lacking.

aigh-resolution low-level counting is the only good way to discern between natural and antiropogenis radioactivity. It is also the only way to obtain information about specific radionuclides and gain insight into the hazard potential of the system. And happily, it is usually the only way that radionuclides Erom SRP low-level waste can be detected, even in the groundwater directly beneath the disposal site 10-25 years after disposal operations have ceased.

As mentioned previously, low-level counting was performed on all of the wells that gave any indication of radioactive contamination in the normal monitoring and high-resolution gamma spectrometric surveys. The methods used included high-resolution gamma spectrometry at SRL's Low-Level Counting Facility. Alpha pulse-height was also performed on each sample following plutonium extraction and electroplating. The detectability of $\mathrm{Cs}-137$ and 
Co-60 was roughly $8 \mathrm{pCi} / \mathrm{L}$, while the detection limit for $\mathrm{Pu}-238$ and Pu-239 was less than 1 pCi/L.

Sr-90 analysis was performed on 2-liter samples by concentrating the water and using the appropriate extraction and counting procedures to measure $y-90$ ingrowth. 27 The detection limit of the method was $6 \mathrm{pCi} / \mathrm{L}$ of $3 \mathrm{r}-90$, and recovery was high $(908)$.

Sample preparation procedures for low-leval gamma spectrometry and alpha pulse height analys is were designed to obtain the maximum sensitivity for activity in the original water sample. With this in mind, samples were acidified to $\mathrm{ph} 2$ prior to filtration with a glass membrane filter, thus preventing adsorption of radionuclides on the sedimentary particles or the filtration apparatus*. This procedure had the ancillary effect of greatly increasing the natural radioactivity that was detected in these samples.

\section{Natural Radioactivity}

The coastal plain sediments that make up the lithology of the burial ground are naturally high in U-238 and $\mathrm{Th}-232$ in the form of monazite. The daughters of these isctopes make up most of the radioactivity that can be detected in the groundwater monitoring wells. Acidification of water samples prior to filtering causes many of the daughters (e. $\mathrm{g} . \mathrm{Bi}-214, \mathrm{~Pb}-212, \mathrm{Ra}-226$ ) to leach from the solids that are suspended in solution during sampling, thus increasing the apparent natural activity.

In soine wells the routine nonvolatile beta-gamma measurements of the monitoring wells are low compared to the natural activity that is released from just a small amount of suspended clay following acidification. For example, in a sample from Well $A-3$, approximately $7 \mathrm{mg}$ of suspended solids contained over $300 \mathrm{pCi} / \mathrm{L}$ of $\mathrm{Pb}-212$ that was leached at $\mathrm{pH} 2$. Because the nonvolatile beta-gamma method selectively removes the activity entrained on suspended solids, it is not detected, and the beta-gamma activity measured by that method in Well A-3 was only $66 \mathrm{pCi} / \mathrm{L}$. Several of the monitoring wells in the burial ground contained $B i-214$ and $\mathrm{Pb}-212$. Filtered and acidified water samples ran as high as $629 \pm$ $148 \mathrm{pCi} / \mathrm{L} \mathrm{Bi-214}$ (Well I-13) and $346 \pm 100 \mathrm{pCi} / \mathrm{L} \mathrm{Pb}-212$ (Well $A-1)$.

Five control wells that were nearby, but completely outside of the burial ground and away from its influence, averaged over 200

* Please note that, as stated in Appendix A, all other samples that required filtration and acidification prior to analysis (e. g., ICP and AA) were first filtered with a Gelman 0.45 micron membrane filter and then acidified with ultrapure (Uitrex) nitric acid. 
$\mathrm{OCi} / \mathrm{L}$ of Bi-214. Samples were acidified and then filtered. Samples that were neither filtered nor acidified averaged slightly igher, but with less consistent results. Pb-212 was also je cectable, and tiwo of the five control wells contained over 300 $\mathrm{pCi} / \mathrm{L}$ of this Th-232 daughter.

\section{Results}

The resulting data (Table Bl) confirm Bowman's final conclusion that none of the groundwater monitoring wells are contaminated by gamma emitters at significant concentrations. In fact, Cs-137 was identified in only three of the wells tested, and co-60 in only one. In all cases, the gamma activities were less than $10 \%$ of the proposed drinking water standards, which are based on a calculated dose of $4 \mathrm{mr} e m$ per person-year. ${ }^{2}$

The data also show that the alpha emitters $\mathrm{Pu}-239$ and $\mathrm{Pu}-238$ are present at extremely low concentrations in some of the monitoring wells. Only one sample exceeded the drinking water standard of $5 \mathrm{pCi} / \mathrm{L}$ for $\mathrm{Pu}-239$. That was an unfiltered sample obtained from well G-2l, which yielded an activity of $10 \mathrm{pci} / \mathrm{L}$. duplicate sample that was filtered and then acidified was $4.0 \pm 1.0$ $\mathrm{pCi} / \mathrm{L}$. Two wells, $\mathrm{A}-3$ and $\mathrm{G}-2 \mathrm{l}$ were above the $5 \mathrm{pCi} / \mathrm{L}$ drinking water standard for $\mathrm{Pu}-238$, with $11.0 \pm 3.0$ and $17.0 \pm 3.0 \mathrm{pCi} / \mathrm{L}$ respectively.

Many of the wells that once contained plutonium, as the result of a TBP-kerosene solvent spill, are now virtually clean. The slope of the gross alpha activity trends over the past five years are decidedly negative (Table Bl, Appendix $B$ ). Three wells were identified as containing $\mathrm{Sr}-90$ above the $8 \mathrm{pCi} / \mathrm{L}$ ( 4 $\mathrm{mrem} / \mathrm{person-year)} \mathrm{drinking} \mathrm{water} \mathrm{standard.} \mathrm{These} \mathrm{were} \mathrm{A-3,} \mathrm{G-21}$ and I-13. Well G-2I contained $1600 \mathrm{pCi} / \mathrm{L}$ of $\mathrm{Sr}-90$. This is over two orders of magnitude more than any other monitoring well in the burial ground.

\section{CHEMICAL ANALYSIS OF 643-G GROUNDWATER}

Based on the statistical treatment described below, and backed up by visual inspection of computer-generated histograms of the data, a group of wells was identified which appeared to have been chemically contaminated by the waste trenches (Table El, Appendix E). The potential influence of the contaminants on the migration behavior of specific radionuclides was evaluated first. The list of wells with high potential radionuclide mobility was then compared to the radioactive contaminant profiles obtained by low-level counting to identify locations where waste chemistry has enhanced radionuclide migration. (Table E1 and E2, Appendix E.) 
Monitoring Well Data Treatment

The groundwater monitoring wells were analyzed Eor jeven disferent cations, five anions, silica, dissolved oxygen, conductivity, pH, total inorganic carbon (TIC) and total organic carbon (TOC). While some of the early data was obtained in 1980 , and some as recently as July, 1982, the bulk of the analyses were performed on samples obtained from March to July of 1981. The values recorded in Table $\mathrm{Cl}$ (Appendix $C$ ) represent the average of all data taken for each well.

Over 1100 water quality parameters have been measured and recorded so far. Of these, roughly 350 (328) were performed at least two times on samples taken from the wells 3 or more months apart. Some of the wells were analyzed for the same parameter three or more times, making it possible to calculate coefficients of variation for samples taken and analyzed at different times o? the year from the same well (Table $\mathrm{C2}$ ). The relative importance a change in any of the parameters can be estimated with some degree of confidence on the basis of this statistical information.

Although statistical treatment of the well analys is data is required to evaluate the apparent trends, it should be remembered that the burial ground is not a random system. Each location in the burial ground is classified according to the kind of material placed there, and the migration mechanisms are likely to be different for each radicnuclide in each type of waste. Therefore, the correlation of statistical outliers (the "abnormal" values for each parameter) with radionuclide contamination in the groundwater is more important than the statistical correlation of a given parameter to a level of contamination. In fact, since radionuclide contamination was generally too low to be neasured, the latter approach was not even attempted.

The water quality parameters for each well were averaged and descriptive statistics were generated for each variable (Tables D1-D22, Appendix D). Most of the parameters of the burial ground well samples were not normally distributed. The Rolomogrov-smirnov test of normality was applied to all of the values for each variable. The null hypothes is in this test is that the data is distributed normally. The test statistic, D, represents the greatest difference between the cumulative distribution of the data and the calculated cumulative distribution of an ideal set (standardized normal sample) with the same mean and standard deviation. With the exceptions of conductivity, ph, nitrate, barium, and strontium, the probability of $D$ exceeding the calculated value was less than 18 , a clear indication ( $p=0.99$ ) that the data were not normally distributed. 
The data were also generally skewed toward values indicating the influence of the waste trenches, as evidenced by the sign and magnitude of their coefficients of skewness and kurtosis (Tables 04-022). This is consistent with the ooservation that the groundwater chemistry in the 643-G burial ground is moderately influenced by the waste in the trenches above it.

wells that were definitely influenced by the waste in the burial ground trenches were identified as follows. The distribution of the data was calculated separately for each variable (Table DI(a), or chemical parameter. Each of the wells were then evaluated separately for each variable. If a measured parameter for a given well was more than three standard deviations from the mean for all wells, it was considered anomalous; such wells were assumed to have been contaminated by waste leachate from the trenches above (or upstream of) them. After the anomalous wells were identified, a new distribution was calculated excluding the anomalous values (Table $D I(b)$ ). The remaining data was then examined a second time, and any additional outliers were identified in the same way.

The anomalous wells with enhanced potential for radionuclide mobility were identified as follows. values ranging above the $95 \mathrm{th}$. cercentile for ionic concentrations, TOC, and conductivity were chosen from the list of extreme values listed for each parameter. Values outside the 5-95th percentile $\mathrm{pH}$ range were selected, and values below the 5 th percentile were selected from the DO and $\mathrm{mV}$ data. These wells are listed in Tables El and are discussed in Appendix E.

\section{General Parameters}

pH

The hydronium ion activity, as represented by the negative logarithm of that quantity ( $p d)$, is one of the most important factors in radionuclide migration. The solubility of many salts, the exchange capacity of the soil, and the prevalence of complexes are all dependent upon $\mathrm{pH}$. The $\mathrm{pH}$ of the groundwater below 643-G is slightly acidic (averaging 5.3). This favors radionuclide solubility, while decreasing the potential for anionic complex formation. The effect of $\mathrm{pH}$ on fluoride, phosphate and carbonate complex formation is shown graphically in Figures 6-8, where the fraction of each of those potentially complexing anions that is available as the free 1 igand is plotted as a function of $\mathrm{pH}$.

With the possible exception of plutonium, only I-129 in the form of silver iodide is immobilized primarily by its lack of solubility. In some cases, it may actually be advantageous that the SRP Low-Level Waste surial Ground is in an acidic environment, 


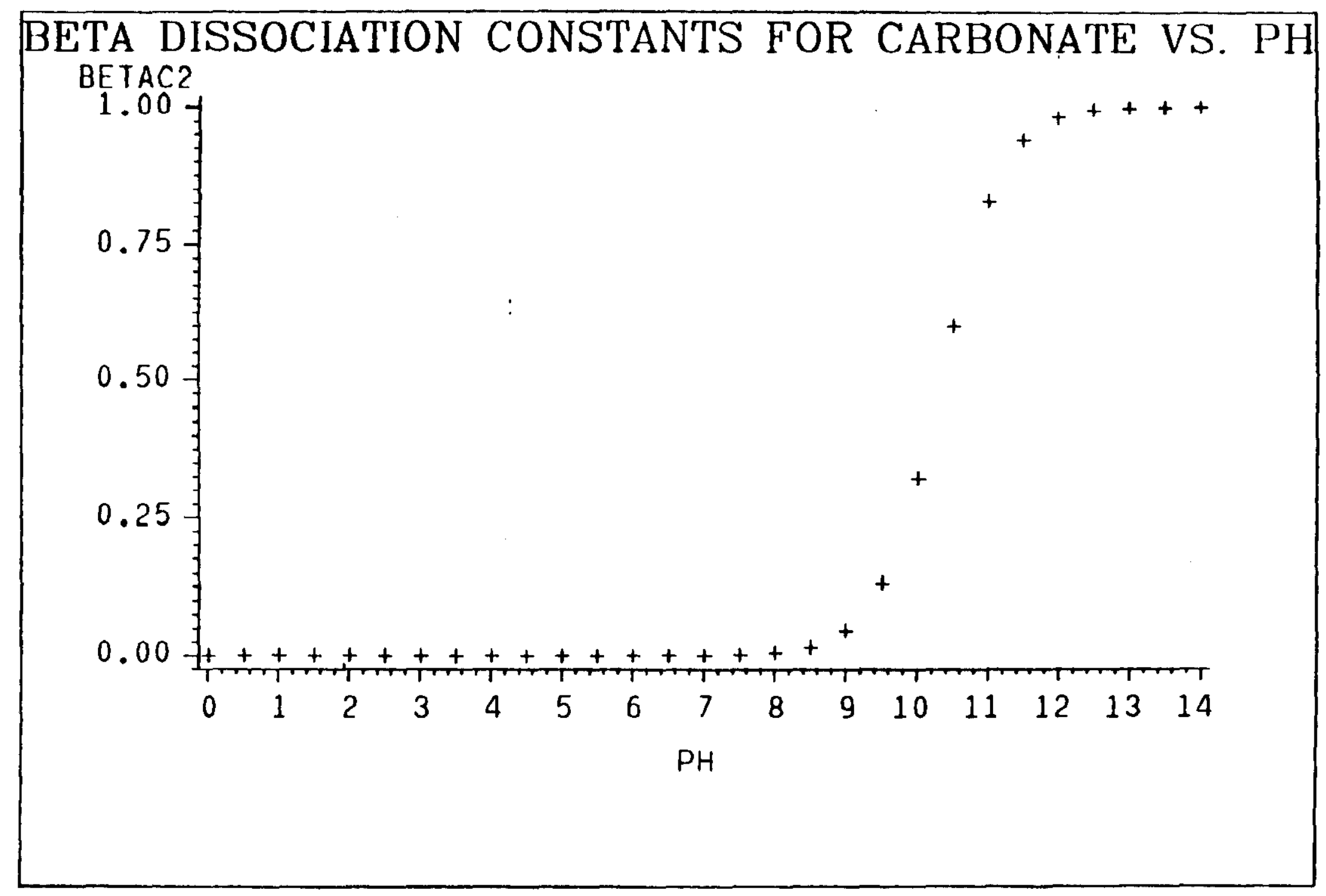

Pigure 6. BETAC2 is the fraction of free carbonate available for precipitation - complexation reactions in a solution containing bicarbonate. 


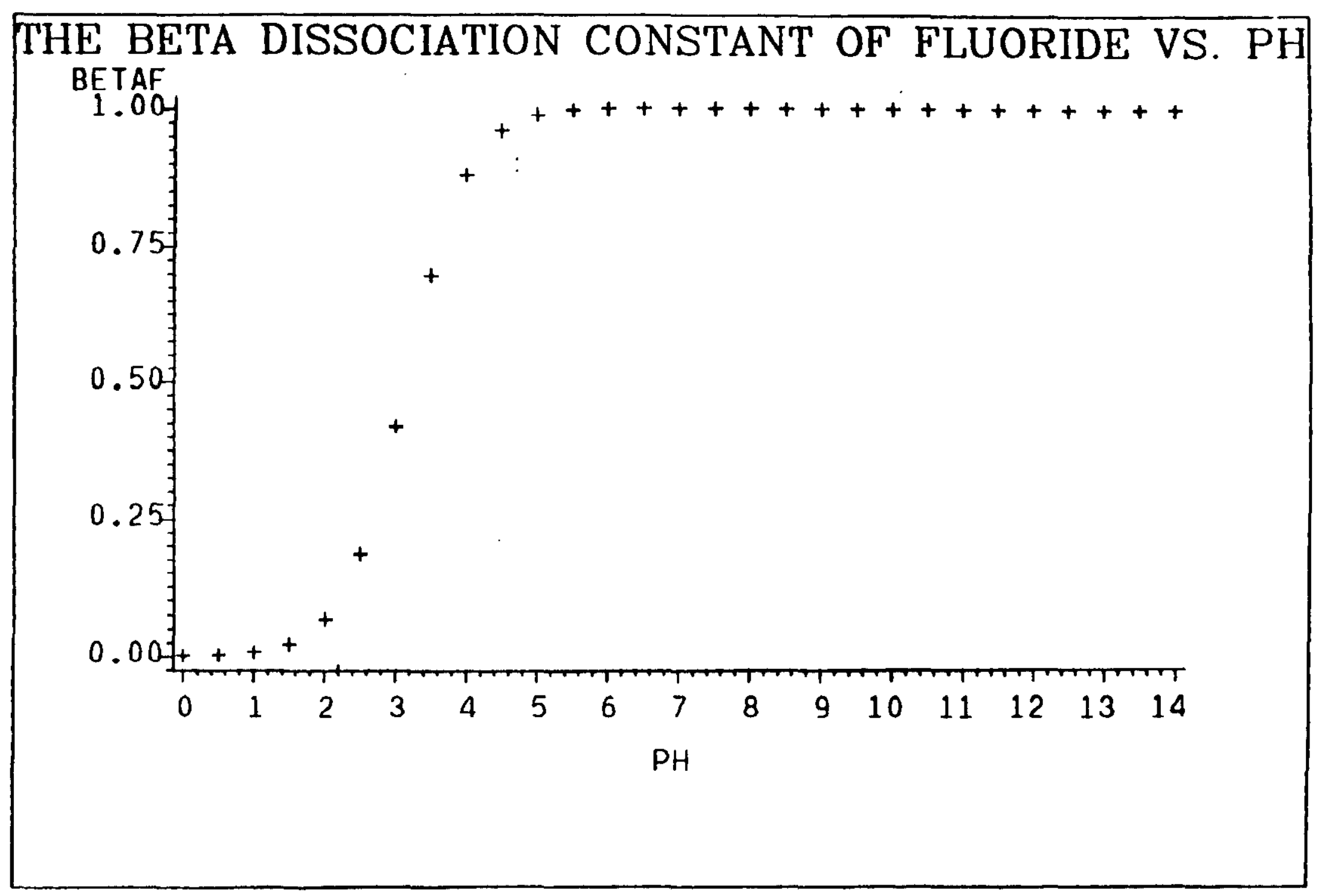

Figure 7. BETAF is the fraction of fluoride avallable for metal complexation in a solution containing hydrogen fluoride. 


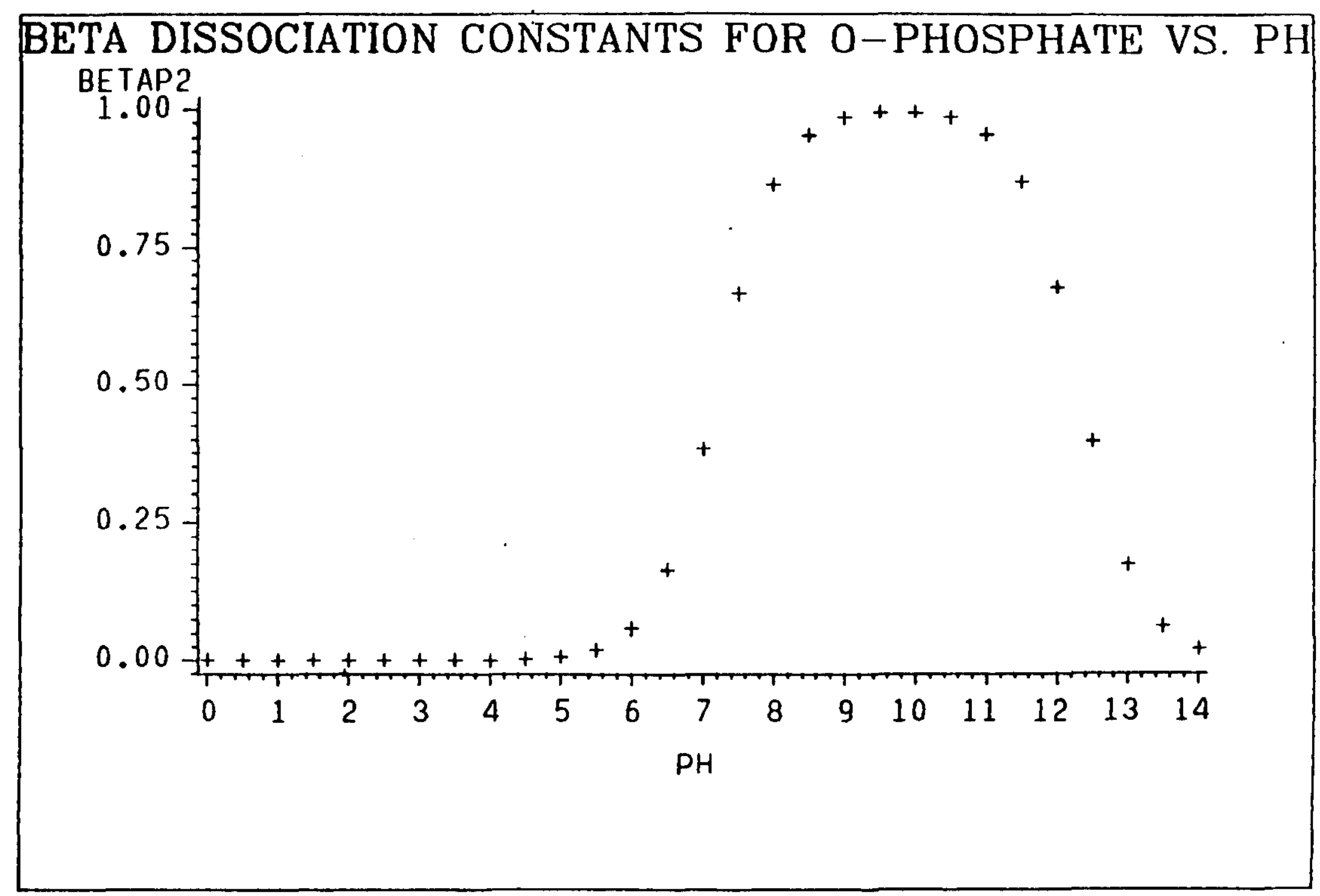

Figure 8. BETAP2 1s the fraction of phosphate present as $\mathrm{HPO}_{4}=$ in a solution containing
phosphoric acid or phosphate. 
because the acid reduces the formation of mobile radioactive complexes. Acidity also favors the reduction of plutonium to the P.1(III) and Pu(IV) state $\{28$ which have a grater arfinity sor soil than oxidized plutonium. 1$\}$

One adverse affect of an acidic environment is a diminished soil (ion) exchange capacity.29 The pH of the groundwater was normally above the isoelectric point (IEP) expected for typical SRP soil. The soil surface potential $\left(I_{0}\right)$ is determined by the equation :

$$
I_{0}=\frac{R T}{F} \text { In } \quad \frac{\left[\mathrm{H}^{+}\right]_{\mathrm{O}}}{\left[\mathrm{H}^{+}\right]}
$$

where

$$
\begin{aligned}
\mathbf{R}= & \text { gas constant } \\
F= & \text { Faraday's constant } \\
{\left[\mathrm{H}^{+}\right]_{0}=} & \text { Hydronium ion concentration at the } \\
& \text { Isoelectric Point (IEP). } \\
{\left[\mathrm{H}^{+}\right]=} & \text {Hydronium ion concentration } \\
\mathbf{T}= & \text { temperature in }{ }^{\circ} \mathrm{K} .
\end{aligned}
$$

and at $25^{\circ} \mathrm{C}$

$$
I_{0}=0.059(\mathrm{pH}-\mathrm{IEP})
$$

As expressed here, positive values of $I_{0}$ favor cation exchange. Therefore, the cation exchange capacity of the soil tends to increase with $\mathrm{oH}$. This has been proven experimentally at SRP where the cation exchange capacity may increase by a factor of I00 irom pH 4 to $\mathrm{pH} 10.13,30$ Kaolinite clay, the dominant clay
mineral in SRP soil, has an Isp of $3.0-4.6 .29,31$

Only two wells were more alkaline than $\mathrm{pH} 7.0$. One well, 8-17, was at $\mathrm{pH} 10$, indicating that a major source of chemical contamination must be leaching from the trenches nearby. * There are several potential effects of such contamination. However, the undesirable effects are essentially only two, the mobilization of radionuclides due to competitive ion exchange, and the formation of mobile radioactive complexes. The first effect, competition for ion exchange sites, is more closely related to ionic strength and the effects of specific cations. The formation of mobile inorganic

* This well was analyzed one year later, (June 1982). The pH had dropped to 7.00 and phosphorus had decreased to less than 0.1 ppm. 


\section{E. L. ALBENESIUS}

complexes is discussed in the sections on phosphate, fluoride and carbonate.

$$
\text { Oxidation - Reduction Potential ( } \left.E_{\mathrm{H}}\right)
$$

The measurement of oxidation-reduction potential in the groundwater monitoring wells is designed to identify excessively reducing environments. Although highly oxidizing environments are possible, the presence of reduced carbon (eg. cardboard, wood, cloth, rubber, etc.) in the trenches gives most of them relatively low oxidation potentials instead, expecially in the presence of biological (bacterial) activity. The oxidation-reduction potential measurement is most meaningful for reduced, non-oxygenated systems, because once at equilibrium, oxygenated systems would not contain enough of the lower oxidation state species of the oxidation-reduction couples to measure with this simple technique.

The oxidation-reduction potential is determined by the potential of one or more couples in solution, but it is not usually measurable with any degree of certainty about the nature of the couple actually being measured. This can have serious drawbacks in the interpretation of $E_{H}$ data for dilute solutions, or in solutions where equilibrium has not been reached among the major sample constituents. Both conditions are prevalent in groundwater systems. The contaminants in the monitoring wells are generally very dilute, and the chromatographic effects of soil adsorption virtually preclude equilibrium in waste-affected sampling locations. The meaning of the measured potential is therefore subject to question.

Possibly the only measureable redox couple of consequence in the groundwater is that of $\mathrm{Fe}(\mathrm{II})-\mathrm{Fe}$ (III). Approximately $10^{-5} \mathrm{M}$ (ie; $0.5 \mathrm{ppm}$ ) concentrations of $\mathrm{Fe}$ (II) and $\mathrm{Fe}$ (III) are required for an exchange current of a microampere at the platinium electrode. 21 This is aporoximately the point at which the electrode can be presumed to be following only the iron couple, successfully rejecting mixed equilibrium potentials. Mn(III)-Mn(IV) could also be considered if the concentration of manganese in the groundwater were sufficiently high.

Although it is generally inferred that a relationship exists between the dissolved oxygen concentration $(D O)$ and the oxidation-reduction potential $\left(E_{H}\right)$, the correlation can be very poor. Under the dynamic conditions present in the burial ground, the oxygen in the groundwater has insufficient time to react completely with reduced components of the waste. Waste components also lack the time to react with each other, so equilibrium is not complete. However, the poor correlation can probably best be 
explained by the fact that most of the wells have no dominant oxidation-reduction couple.

The three wells that contained more than 1 pom of iron all had low dissolved oxygen concentrations and low redox potentials, but the Eh of the two wells that contained iron at $0.5-0.8 \mathrm{ppm}$ appeared to be more closely related to the $\mathrm{pH}$ and nitrate couple than to dissolved oxygen. This is plausible, since the reduction of nitrate is dependent on $\mathrm{pH}$, but not necessarily on oxygen concentration (for a system not at equilibrium). However, the kinetics of nitrate reduction indicate that it is still the iron couple that is actually being measured. 32

The oxidation reduction potential of the groundwater was measured as high as 0.683 volts versus the standard (or normal) hydrogen electrode (Well $c-13$ ). But even this was too low to allow a significant amount of plutonium to exist in the Pu(VI) or $\mathrm{Pu}$ (IV) states. Except in strong complexes, trace levels of plutonium should be either as $\mathrm{Pu}$ (III) or $\mathrm{Pu}(V)$, depending on the oxidation potential and $\mathrm{pH}$ of the system.28,33-35 The potentials required to convert these to $\mathrm{Pu}(\mathrm{IV})$ and $\mathrm{Pu}(\mathrm{VI})$ are given below. 28

$$
\begin{array}{lll}
\mathrm{PuO}_{2}^{2+}+\mathrm{e}^{-}=\mathrm{PuO}_{2}^{+} & \frac{\mathrm{E}^{\circ} \text { (volts) }}{+0.93} \\
\mathrm{Pu}^{4+}+\mathrm{e}^{-}=\mathrm{Pu}^{3+} & +0.97
\end{array}
$$

Unlike the equilibria described above, the conversion of $\mathrm{Pu}(\mathrm{V})$ to $\mathrm{Pu}(\mathrm{III})$ and $\mathrm{Pu}(\mathrm{VI})$ to $\mathrm{Pu}(\mathrm{IV})$ are highly $\mathrm{pH}-\mathrm{dependent.}$

$$
\begin{array}{lc}
\mathrm{PuO}_{2}^{+}+4 \mathrm{H}^{+}+2 \mathrm{e}^{-}=\mathrm{Pu}^{3+}+2 \mathrm{H}_{2} \mathrm{O} & \frac{\mathrm{E}^{\circ} \text { (volts) }}{1.06} \\
\mathrm{PuO}_{2}^{2+}+4 \mathrm{H}+2 \mathrm{e}^{-}=\mathrm{Pu}^{4+}+2 \mathrm{H}_{2} \mathrm{O} & 1.03
\end{array}
$$

The next equation can be used to establish the equilibrium constant at various solution potentials $\left(E_{H}\right)$ of the groundwater. At equilibrium $E=E_{H}$.

$$
E=1.06+\frac{0.059}{2} \log \frac{\left[\mathrm{PuO}_{2}^{+}\right]}{\left[\mathrm{Pu}^{3+}\right]}+0.12 \mathrm{pH}
$$

Inspection of this equation reveals that a one $\mathrm{pH}$ unit change in acidity affects the ratio of Pu(V) to Pu(III) by a factor of 104, with greater acidity favoring the lower oxidation state. A change in the solution potential of $100 \mathrm{millivolts}$ has slightly less effect, altering the ratio by a factor of $10^{3.3}$. 
The relationship between $P U(V I)$ and $P U(I V)$ would be the same way, but for the dominance of the $\mathrm{Pu}(\mathrm{V})$ and $\mathrm{Pu}(\mathrm{III})$ forms that exist at the oxidation potential of most natural systems.

As a result of these equilibria, the most favorable conditions for retaining plutonium on the soil in a complex system is to maintain a moderate oxidation potential under slightly acidic conditions. This will stabilize Pu(III), which is the least mobile of all the plutonium species.

\section{Dissolved Oxygen (DO)}

Dissolved oxygen is measured in parts per million at the temperature (TEMP) listed for each well. This parameter is related to radionuclide mobility in two ways. It is a measure of the reducing character of the water, in that low dissolved oxygen concentrations result from oxygen consumption in a reducing environment at or upstream of the sampling location. It is also an indicator of the relative isolation of the sampling location from the flow of oxygenated water, giving some indication of the relative dominance of the waste chemistry.

High dissolved oxygen concentrations in the waste trenches and. in the groundwater around such trenches are generally good in terms of radionuclide isolation, but technicium, ruthenium, and plutonium are much more mobile in their most oxidized states. The major drawback to highly reducing environments is the fact that Fe(II) often becomes dominant in such systems, eliminating or attenuating the affinity of the soil (metal-oxide layer) for radionuclides such as sr-90. The higher ionic strength of such aqueous systems also uses up the ion exchange capacity of the surrounding soil, further mobilizing the cationic radionuclides.

Other contamination problems are encountered in highly oxygenated systems. Ruthenium VI and VII are anionic, but they are also unstable at the slightly acidic pH of the burial ground system, even in oxygen-saturated systems.28 Nitrosyl complexes of Ruthenium II and III are probably the main component of mobile Ru-106 at SRP. Technetium is mobile only as the pertechnetate $\left(\mathrm{TCO}_{4}{ }^{-}\right)$anion, 20 which is its normal oxidation state (VII) in groundwater. Reducing conditions in the trenches could immobilize Tc-99 temporarily, but its long half-life makes its eventual escape to the groundwater certain. Fortunately, low specific acivity, low decay energy, and short biological half-iife combine to make Tc-99 relatively harmless. Plutonium is most stable as Pu(III) (See Fluoride) in aqueous environmental systems, although $P u I V, V$, and possibiy even VI are also present. Plutonium speciation is not directly affected by variations the dissolved oxygen concentration, 
but low dissolved oxygen concentrations may indicate the proximity of a reducing system that could also react with Pu(VI) and PU(IV).

\section{Conductivity (COND)}

Ionic strength is approximately Iinearly related to conductivity. Both parameters are thus related to the activity coefficients of the radionuclides in a given system. For the most part the ionic strength of the well water samples was so low that the activity coefficient could be considered unity. Activity coefficients were calculated (Debye-Huckel) for $\mathrm{Cs}^{+}$and $\mathrm{Sr}^{2+}$ in the normal and higher ionic strength groundwater, but the differences over the observed range of ionic strengths were negligible.

The most important aspect of conductivity (and ionic strength), then, is as a measure of the ion exchangeable material in solution that could compete with radionuclides for adsorption (exchange) sites on the soil. More specific information about the wells will be given under the heading "Competing Cations." However, electrically conductive groundwater generally has the greatest potential for transporting exchangeable, cationic radionuclides (see sodium). Therefore, the most conductive wells (G-7, G-21, I-13 and possibly A-5) would be suspected of containing. dissolved radionuclides.

\section{Complexing Anions}

\section{Total Inorganic Carbon (TIC)}

Inorganic carbon (carbonate) has a strong impact upon the properties of groundwater. As dissolved carbon dioxide (carbonic acid) it tends to reduce the $\mathrm{pH}$ of natural groundwaters. In the form of carbonate and bicarbonate salts, it contributes to the alkalinity of the groundwater and makes up much of the buffering capacity of natural systems. The carbonate anion can form an insoluble salt with strontium, but under certain conditions it can also form mobile, anionic complexes with plutonium and uranium. At $S R P$, the latter effect is more important.

The fraction of the total carbonate in a given solution that is actually present as the free, divalent anion is referred to in this paper as BETAC2. The fraction is constant at a given pH. The dependence of BETA upon $\mathrm{pH}$ is illustrated in Figure 6. It can be seen from this figure that only a small fraction of the carbonate remains freely available at the $\mathrm{pH}$ of the normal groundwater at SRP. 
are: 28,36 equations that apply to the dissociation of carbonic acid

\section{Equation}

$[1] \mathrm{H}_{2} \mathrm{CO}_{3}=\mathrm{H}^{+}+\mathrm{HCO}_{3}^{-}$

[2] $\mathrm{HCO}_{3}^{-}=\mathrm{H}^{+}+\mathrm{CO}_{3}=$

The free carbonate fraction is BETAC2
Disjooiation

\section{Constant}

$4.7 \times 10^{-11}$

[3] $\operatorname{BETAC} 2=\frac{\left[\mathrm{CO}_{3}=\right]}{\left[\mathrm{H}_{2} \mathrm{CO}_{3}\right]+\left[\mathrm{HCO}_{3}-\right]+\left[\mathrm{CO}_{3}=\right]}$

[4] $\operatorname{BETAC2}=\frac{1}{\left[\mathrm{H}^{+}\right]^{2} / \mathrm{k}_{\mathrm{I}} \mathrm{k}_{2}+\left[\mathrm{H}^{+}\right] / \mathrm{k}_{2}+1}$

where $k_{1}$ and $k_{2}$ are the dissociation constants of equations 1 and 2 respectively.

The formation of insoluble strontium carbonate is described by the solubility product equation,

$$
\mathrm{srCO}_{3}=\mathrm{sr}^{2+}+\mathrm{Co}_{3}^{2-} \quad \mathrm{ksp}=5.62 \times 10^{-10}
$$

To calculate the solubility of strontium, the molar concentration of carbonate is first calculated from $T$ IC (in pom of carbon) as follows:

[6] $\left[\mathrm{CO}_{3}^{2-}\right]=\frac{\text { IIC }}{I 2,000}$ BERAC2

The solubility of strontium is then:

[7] $\left[\mathrm{Sr}^{2+}\right]=\frac{5.62 \times 10^{-10}}{\left[\mathrm{CO}_{3}^{2-}\right]}$ 
It can be shown through the application of thes a basic equations that none of the monitoring wells are close to being saturated with strontium. The application of similar eguations For caicium 23

[8] $\left[\mathrm{Ca}^{2+}\right]=\frac{7.08 \times 10^{-4}}{\left[\mathrm{CO}_{3}{ }^{2-}\right]}$ (ksp of amorphous $\mathrm{CaCO}_{3}=7.08 \times 10^{-4}$ )

results in the same conclusion, that subsaturation conditions exist in all of the wells. Neither calcium nor strontium is present as the carbonate salt, so Sr-90 cannot be immobilized as an inclusion. At SRP, the (relatively low concentrations or) calcium and strontium in the groundwater merely serva to compete with ion exchange sites on the soil, while the carbonate serves as a counterion for their dissolution. This equilibrium is shifted somewhat for calcite, which has a ksp of $4.5 \times 10^{-9}$. Only well c-5 contains calcium at saturation levels with respect to this mineral ( $100 \mathrm{ppm} \mathrm{Ca}$ in $1.8 \times 10^{-6} \mathrm{M}$ free carbonate). Well E-19 is the only other well above 208 saturation in $\mathrm{CaCO}_{3}$, being 92.68 saturated.

Plutonium (VI) and uranium (VI) both form anionic complexes with carbonate. The related equations are ${ }^{28}$ :

$$
\mathrm{Pu}(\mathrm{s})=\mathrm{Pu}^{4+}+4 \mathrm{e}^{-}
$$

$$
\mathrm{PuO}_{2}\left(\mathrm{CO}_{3}\right)_{2}^{2-}+4 \mathrm{H}^{+}+2 \mathrm{e}^{-}=\mathrm{Pu}^{4+}+2 \mathrm{CO}_{3}^{2-}+2 \mathrm{H}_{2} \mathrm{O}
$$

$$
\mathrm{PuO}_{2} \mathrm{COO}_{3} \mathrm{OH}^{-}+5 \mathrm{H}^{+}+2 \mathrm{e}^{-}
$$$$
=\mathrm{Pu}^{4+}+\mathrm{CO}_{3}^{2-}
$$

$$
\mathrm{PuO}_{2} \mathrm{CO}_{3}(\mathrm{OH})_{2}^{2-}+6 \mathrm{H}^{+}+2 \mathrm{e}^{-}=\mathrm{Pu}^{4+}+\mathrm{CO}_{3}^{2-}+4 \mathrm{H}_{2} \mathrm{O} 39.83
$$

Combining these equations gives the following relationships for Pu(VI).

$$
\begin{aligned}
& \mathrm{PuO}_{2}^{2+}+\mathrm{CO}_{3}^{2-}=\mathrm{PuO}_{2} \mathrm{CO}_{3} \\
& \mathrm{PuO}_{2}^{2+}+2 \mathrm{CO}_{3}^{2-}=\mathrm{PuO}_{2}\left(\mathrm{CO}_{3}\right)_{2}^{2-}
\end{aligned}
$$

$\log \mathrm{k}$

$$
\mathrm{PuO}_{2}^{2+}+\mathrm{CO}_{3}^{2-}+\mathrm{H}_{2} \mathrm{O}=\mathrm{PuO}_{2} \mathrm{CO}_{3} \mathrm{OH}^{-}+\mathrm{H}^{+}
$$


E. L. ALBENESIUS

DPST $-83-209$

(18) $\mathrm{PuO}_{2}^{2+}+\mathrm{CO}_{3}^{2-}+2 \mathrm{H}_{2} \mathrm{O}=\mathrm{PuO}_{2} \mathrm{CO}_{3}(\mathrm{OH})_{2}^{2-}+2 \mathrm{H}^{+}$

The ratio of the concentrations of the major anionic carbonate species with respect to the concentration of free (cationic) Pu(VI) is then given by:

[20]

$$
\frac{\left[\mathrm{PuO}_{2}\left(\mathrm{CO}_{3}\right) \frac{2-}{2}\right]}{\left[\mathrm{PuO}_{2}^{2+}\right]}=\left[\mathrm{CO}_{3}^{2-}\right]^{2} \times 10^{14.92}
$$

$$
\frac{\left[\mathrm{PuO}_{2}\left(\mathrm{CO}_{3}\right) \mathrm{OH}^{-}\right]}{\left[\mathrm{PuO}_{2}^{2+}\right]}=\frac{\left[\mathrm{CO}_{3}^{2-}\right]}{\left[\mathrm{H}^{+}\right]} \times 10^{9.83}
$$

Where each of the quantities in brackets represents the molar concentration of that species, and the carbonate concentration is calculated as before (i.e., $\left.\left[\mathrm{CO}_{3}{ }^{-}\right]=\mathrm{TIC} / 12,000 \times \mathrm{BETAC} 2\right)$.

These equations were applied to each of the water compositions found in the monitoring wells. The results of these calculations showed that the anionic plutonium hydroxycarbonate species was often favored over both the cationic Pu(VI) and the neutral $\mathrm{PuO}_{2} \mathrm{CO}_{3}$ species by several orders of magnitude. The $\mathrm{PuO}_{2}\left(\mathrm{CO}_{3}\right) 3$-complex was not favored with respect to neutral $\mathrm{PuO}_{2} \mathrm{CO}_{3}$ (see Table I).

The thermodynamic dominance of the anionic hydroxycarbonate species may be an additional factor in explaining the trace level mobility of plutonium in the northwest corner of the 643-G burial ground (wells $\mathrm{A}-3, \mathrm{C}-1$, and $\mathrm{C}-3$ ). However, there is still a question concerning the stability of Pu(VI) in the environment $37,38,39$ (see also Oxidation-Reduction Potential). Its reduction potential is so high that it is certainly reduced to $\mathrm{Pu}(V)$, (IV), and (III) in most trench burial regimes. These do not form anionic carbonate (or fluoride) complexes in the environment and are, therefore, adsorbable by the soil. still, the existence of a mobile complexed Pu(VI) species could help to explain the trace levels of plutonium that were detected in the groundwater. If so, some enrichment of Pu(VI) would have occurred through selective adsorption and retention of the reduced plutonium species along the path of migration.

Probably the best way to estimate the potential of a system for the formation of plutonium hydroxycarbonate is to consider an equilibrium between that species and the anionic hydroxide complex of $\mathrm{Pu}(\mathrm{IV})$. 
TABLE 1

\section{ANION/CATION SPECIATION RATIOS}

FOR PU (VI) WITH CARBONATE

\begin{tabular}{|c|c|c|c|c|c|}
\hline CASE & $p H$ & $\begin{array}{c}{\left[\mathrm{CO}_{3}\right]_{\mathrm{T}}} \\
\text { (moles/]iter) }\end{array}$ & $\mathrm{BETACO}_{3}$ & $\frac{\mathrm{PuO}_{2}\left(\mathrm{CO}_{3}\right) \mathrm{OH}^{-}}{\mathrm{PuO}_{2}^{2+}}$ & $\frac{\mathrm{PuO}_{2}\left(\mathrm{CO}_{3}\right)_{2}^{2-}}{\mathrm{PuO}_{2}^{2+}}$ \\
\hline MEDIAN & 5.3 & $1.1 \times 10^{-3}$ & $9.1 \times 10^{-6}$ & $1.4 \times 10^{7}$ & $8.3 \times 10^{-2}$ \\
\hline $\begin{array}{l}\text { J JRST } \\
\text { REAL }\end{array}$ & 6.86 & $5.3 \times 10^{-3}$ & $3.4 \times 10^{-4}$ & $8.8 \times 10^{10}$ & $2.7 \times 10^{3}$ \\
\hline $\begin{array}{l}\text { HIGH } \\
\text { CARBONATE }\end{array}$ & 5.3 & $1.0 \times 10^{-2}$ & $9.1 \times 10^{-6}$ & $1.2 \times 10^{8}$ & 6.9 \\
\hline $\mathrm{HIGH}$ & 10.0 & $1.1 \times 10^{-3}$ & 0.32 & $2.4 \times 10^{16}$ & $1.0 \times 10^{8}$ \\
\hline
\end{tabular}


Written as a reduction:

[2I] $\mathrm{PuO}_{2}\left(\mathrm{CO}_{3} \mathrm{OH}^{-}+2 \mathrm{H}_{2} \mathrm{O}+2 \mathrm{e}^{-}=\mathrm{Pu}(\mathrm{OH})_{5}^{-}+\mathrm{CO}_{3}^{2-}\right.$

$\underline{\log k}$ 10.08

(Derived using equations 22 and 23

from Benson and Teague ${ }^{28}$,

[22] $\mathrm{PuO}_{2}\left(\mathrm{CO}_{3}\right) \mathrm{OH}^{-}+5 \mathrm{H}^{+}+2 \mathrm{e}^{-}=\mathrm{Pu}^{4+}+\mathrm{CO}_{3}^{2-}+3 \mathrm{H}_{2} \mathrm{O}$

$$
\mathrm{Pu}(\mathrm{OH})_{5}^{-}+5 \mathrm{H}^{+}=\mathrm{Pu}^{4+}+5 \mathrm{H}_{2} \mathrm{O}
$$

The reduction potential for this cell $\left(E^{\circ}\right)$ is derived from the Gibbs Free Energy relationship

[24] $G^{0}=n F E^{0}=-R T$ in $K_{1}$

[25] $E^{\circ}=\frac{0.059}{2} \log K_{1}$

Substituting 10.08 for $\log k_{2}$

$$
E^{\circ}=0.296 \mathrm{~V}
$$

the equilibrium is then defined by the Nernst equation

$[26] E=0.296+\frac{0.59}{2} \log \frac{\left[\mathrm{PuO}_{2}\left(\mathrm{CO}_{3}\right) \mathrm{OH}^{-}\right]}{\left[\mathrm{Pu}(\mathrm{OH})_{5}\right]\left[\mathrm{CO}_{3}^{2-}\right]}$

A worst case can then be calculated for the source, assuming that the free carbonate and Pu(IV) concentrations can be calculated. These are estimated to be $10^{-7}$ and $10^{-8}$ molar, respectively as an approximation to the worst case.

The amphoteric behavior of $\mathrm{Pu}(\mathrm{OH})_{4}$ as described in

equation [23], and the hydrolysis of $\mathrm{Pu} 4+$ to insoluble $\mathrm{Pu}(\mathrm{OH}) 4$, can be related to $\mathrm{PuO}_{2}\left(\mathrm{CO}_{3}\right) \mathrm{OH}^{-}$. At $\mathrm{pH} 6, \mathrm{Pu}(\mathrm{OH})_{5}^{-}$is roughly $10^{15}$ times the Pu4t concentration. Pu4t, as limited by hydrolys is is roughly 10-23 M. This agrees well with empirical evidence that plutonium exists at these $\mathrm{pH}^{\prime} \mathrm{s}$ at concentrations of roughly $10^{-9} \mathrm{M}$ (ionic strength $=1.01 .40$ The highest free carbonate concentration in the groundwater is about $10^{-7} \mathrm{M}$. 
After substituting the appropriate values into equation $(6)$ the resulting calculation gives $13^{-5} \mathrm{M}$ slutonium at a reaox ootential of $600 \mathrm{mV}$ (SiE). Inis is rougily 250 r.Ci/i of piutoniun as Pu-239. This estimate gives a base ïigure representing only the maximum concentration of $P u(V I)$ hydroxycarbonate that could occur in the diffusion layer around Plutonium(IV) hydroxide in its standard state. This "source concentration" would diminish exponentially with the distance travelled through the soil, and away from the source, because of the conversion of Plutonium(VI) to (V) and (IV) and their subsequent adsorption by the soil. 41

Away from a plutonium source (saturated solubility conditions) the dominant Eactor in Pu(VI) transport is the equilibrium with pu(V), which does not form a stable anionic complex with carbonate. $\mathrm{Pu}(\mathrm{V})$ was more than 104 times more thermodynamically stable than Pu(VI) in water from every groundwater monitoring well in the $643-G$ burial ground. Therefore, plutonium(VI) is rapidly converted to Plutonium( $V)$ in the presence of any redox couple in the groundwater (even at $\mathrm{E}_{\mathrm{H}}=+0.6$ volts). Since the hydroxycarbonate species must be in equilibrium with Pu(VI), it is gradually consumed through the adsorption of the reduced plutonium in soil.

In terms of operating low-level burial sites in a humid environment, it would seem to be advantageous to avoid discosing of plutonium in a highly oxidizing environment. 38 This constraint would not normally affect disposal operations, but it would assure that plutonium mobility would not be enhanced by conversion to the oxidized Pu(V) and Pu(VI) species, the latter of which is mobile in the presence of basic or neutral carbonate.

\section{Total organic Carbon (TOC)}

The groundwater in the vicinity of the burial ground is naturally oxic, and contains very little natural organic carbon. Aside from small amounts of humic material Erom areas that might have been low or marshy prior to burial ground operation (none have been identified) virtualiy all of the organic carbon dissolved in the groundwater must have come from the trenches. Some of this material is most likely in the form of acidic and potentially complexing compounds.

The nature of organic contaminants in the groundwater and burial ground trenches is critical to the mobility of plutonium. organics that form strong complexes tend to mobilize Pu(IV) very efficiently. The most critical compounds in this respect are EDTA and its analogs (eg., EDTA and DTPA), but others such as TBP, DEHP, and even citrate could carry plutonium to the water tajle at trace levels. Plutonium(IV) forms such strong complexes that it competes favorably with naturally occurring $F($ (II) and $\mathrm{Ca}$ in the 
groundwater for sub-stoichiometric concentrations of these anions. $34,36,42$

Several of the monitoring wells contain measurable amounts of dissolved organic carbon. Some of these, including C-17, E-2l and G-21, are located near the old solvent burning trenches. Others, like G-7, contain high concentrations of dissolved carbon for no apparent reason. Until an analysis of the organic material in the monitoring wells is completed, the source and potential impact of the organic carbon will be uncertain.

\section{Fluoride}

Fluoride is usually found at such low concentrations in groundwater that it is not important in radionuclide migration studies. Normally, it does not affect the mobility of fission products, although at high concentration, fluoride can precipitate $\mathrm{Cm}, \mathrm{Cr}, \mathrm{Ni}$, and Sr. The importance of fluoride here is its ability to form anionic, and therefore mobile, complexes with plutonium and uranium in their most oxidized valence states. PuO $\mathrm{F}_{4}{ }^{2-}$ and $\mathrm{PuO}_{2} \mathrm{~F}_{3}{ }^{-}$ are the most thermodynamically stable species of plutonium(VI) in aqueous media at concentrations of about $5 \times 10^{-6} \mathrm{M}$ fluoride and above. 28 Uranium( $(Y)$ is stable as $0_{2} \mathrm{~F}_{4}{ }^{2-}$ at concentrations greater than about $1 \times 10^{-3}$ M fluoride.

The equilibrium concentration of anionic fluoride complexes relative to PuO $2_{2}^{+}$and $\mathrm{UO}_{2}^{2+}$ concentrations were calculated from basic thermodynamic data 28,33 as follows.

For Uranium:

Equation

$\log \mathrm{k}$

[1]

$$
\mathrm{UO}_{2}^{+}+4 \mathrm{H}^{+}+2 \mathrm{e}^{-}=\mathrm{U}^{4+}+2 \mathrm{H}_{2} \mathrm{O}
$$

[2]

$$
\mathrm{NO}_{2} \mathrm{~F}_{3}^{-}+4 \mathrm{H}^{+}+2 \mathrm{e}^{-}=\mathrm{U}^{4+}+3 \mathrm{~F}^{-}+2 \mathrm{H}_{2} \mathrm{O}
$$

$$
\mathrm{UO}_{2} \mathrm{~F}_{4}{ }^{-}+4 \mathrm{H}^{+}+2 \mathrm{e}^{-}=\mathrm{U}^{4+}+4 \mathrm{~F}^{-}+2 \mathrm{H}_{2} \mathrm{O}
$$

$$
\begin{aligned}
& {[1-3] \mathrm{UO}_{3^{+}}+4 F^{-}=\mathrm{UO}_{2} \mathrm{~F}_{4}{ }^{2-}} \\
& {[1-2] \mathrm{UO}_{2}{ }^{+}+3 \mathrm{~F}^{-}=\mathrm{UO}_{2} \mathrm{~F}_{\overline{3}}}
\end{aligned}
$$


E. L. ALBENESIUS

Therefore:

$$
\begin{aligned}
\frac{\left[U O_{2} F_{4}^{2-}\right]}{\left[U O_{2}^{2+}\right]} & =\left[F^{-}\right]^{4} \times 10^{12.98} \\
\frac{\left[U O_{2} F_{3}^{-}\right]}{\left[U O_{2}^{2+}\right]} & =\left[F^{-}\right]^{3} \times 10^{11.79} \\
{\left[F^{-}\right] } & =(B E T A F) \times([F] \text { measured })
\end{aligned}
$$

BETAF, the fraction of fluorine present as the fluoride anion, is:

$$
\operatorname{BETAF}=\frac{\left[F^{-}\right]}{\left[F^{-}\right]+[\mathrm{HF}]}=\frac{1}{\left[\mathrm{H}^{(+)}\right] / D S+1}
$$

Where:

$$
\mathrm{DS}=\frac{\left[\mathrm{H}^{+}\right]\left[\mathrm{F}^{-}\right]}{[\mathrm{HE}]}=7.2 \times 10^{-4}
$$

And For Plutonium:

Equation

$\underline{\log k}$

$$
\mathrm{PuO}_{2}^{2+}+4 \mathrm{H}^{+}+2 \mathrm{e}^{-}=\mathrm{Pu}^{4+}+2 \mathrm{H}_{2} \mathrm{O}
$$

[2]

$$
\mathrm{PuO}_{2} \mathrm{~F}_{3}^{-}+4 \mathrm{H}^{+}+2 \mathrm{e}^{-}=\mathrm{Pu}^{4+}+3 \mathrm{~F}^{-}+2 \mathrm{H}_{2} \mathrm{O}
$$

[ 3]

$$
\mathrm{PuO}_{2} \mathrm{~F}_{4}^{2-}+4 \mathrm{H}^{+}+2 \mathrm{e}^{-}=\mathrm{Pu}^{4+}+4 \mathrm{~F}^{-}+2 \mathrm{H}_{2} \mathrm{O}
$$

$$
\mathrm{PuO}_{2}^{2+}+4 \mathrm{~F}^{-}=\mathrm{PuO}_{2} \mathrm{~F}_{4}^{2-}
$$

$[1-2]$

$$
\mathrm{PuO}_{2}^{2+}+3 \mathrm{~F}^{-}=\mathrm{PuO}_{2} \mathrm{~F}_{3}^{-}
$$

$+16.25$

\section{Therefore:}

$$
\frac{\left[\mathrm{PuO}_{2} \mathrm{~F}_{3}^{-}\right]}{\left[\mathrm{Pu}_{2}^{2+}\right]}=\left[\mathrm{F}^{-}\right]^{3} \times 10^{16.26}
$$




$$
\begin{aligned}
\frac{\left[\mathrm{PUO}_{2} \mathrm{~F}_{4}^{2-}\right]}{\left[\mathrm{PUO}{ }_{2}^{2+}\right]} & =\left[\mathrm{F}^{-}\right]^{4} \times 10^{19.29} \\
{\left[\mathrm{~F}^{-}\right] } & =(\mathrm{BETAF}) \times\left([\mathrm{F}]_{\text {measured }}\right)
\end{aligned}
$$

The fluorine concentration statistics for the groundwater wells are summarized in Table 2. The average fluoride concentration in all wells was $0.1 \mathrm{ppm}\left(5 \times 10^{-6} \mathrm{M}\right)$. The highest concentration measured was $0.8 \mathrm{ppm}\left(4 \times\right.$ i $\left.0^{-5} \mathrm{M}\right)$. The fraction of the total fluorine actually present as free fluoride (BETAF) is a function of pH. This function is plotted in Figure 7 .

Using the equations above, the ratios of anionic Pu(VI) and $U(V I)$ concentrations to the concentrations of the corresponding anionic fluoride complexes were calculated for the average and the highest fluoride concentrations that were measured in the groundwater wells (Table 2). The potential impact of the elevated fluoride concentrations is well illustrated by the effect of just $1 \times 10^{-3} \mathrm{M}$ fluoride on the equilibrium ratio of anionic to cationic species of both uranium and plutonium. And, as seen in the table, even the low concentrations of fluoride that were measured in the groundwater wells could have a significant impact upon the speciation of Pu(VI).

Pu(VI) may represent a significant fraction of the soluble, mobile plutonium in the 643-G groundwater, and its mobility is almost certainly enhanced by the formation of anionic and neutral complexes. A study of plutonium speciaton in well $\mathrm{C}-17$ concluded that over $40 \%$ of the dissolved, unfilterable plutonium was Pu(VI). 39*

The same study found that some of the plutonium in well $\mathrm{c}-17$ may have been adsorbable by anion exchange resin (in the chloride form), but the results were statistically uncertain - the absolute quantity of such material being represented by the difference between $32.0 \pm 3.0 \mathrm{pCi} / \mathrm{L}$ and $28.4 \pm 4.2 \mathrm{pCi} / \mathrm{L}$. Additional tests showed that almost 968 of the soluble plutonium could be adsorbed on cation exchange resin (in the acid form), but only 758 was adsorbed on soil in batch $\mathrm{K}_{\mathrm{d}}$ tests. Therefore, although very little anionic plutonium was detected by direct extraction with ion exchange resins, some anionic plutonium probably does exist.

* Some or all of the Pu(VI) that was detected may have been Pu(V), a species that does not form stable complexes. 
ANION/CATION SPECIATION RATIOS* FOR U (VI) AND PU (VI) WITH FLUORIDE

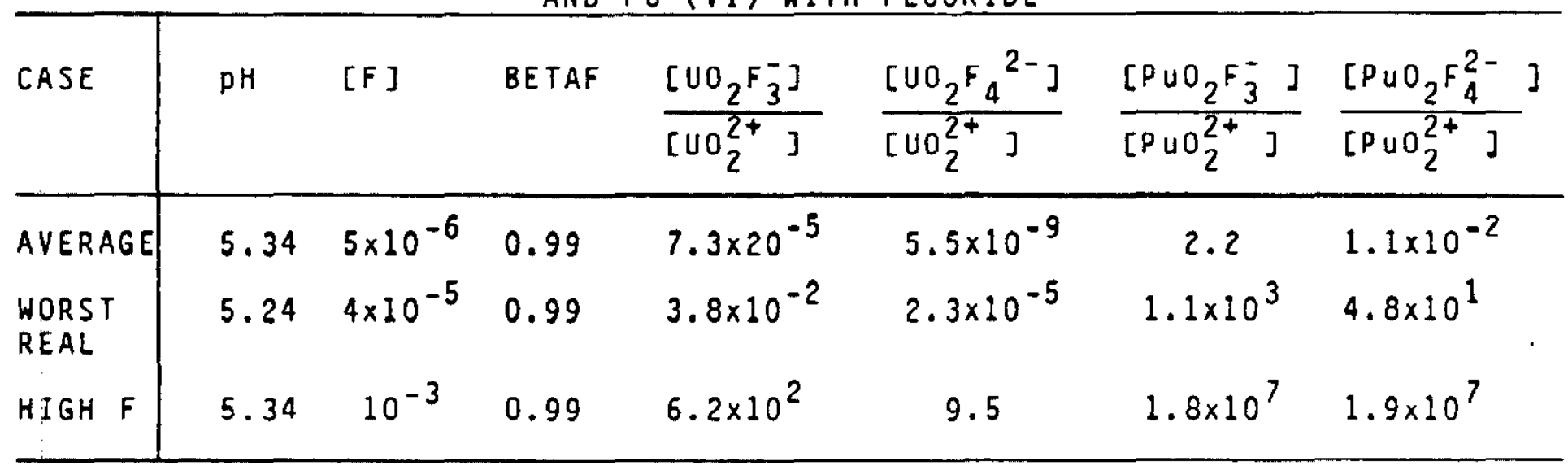

* At thermodynamic equilibrium 
More than half of the soluble oxidized olutonilim in the experimental water sample (from well $\quad$ - 17 ) may haye bean in the form of anionic Pu(VI) complexes. The eulilib:in c $\exists=i$ io for Pu(VI) in an aqueous system with 0.1 ppm total filuorine as a za oE 5.15 is roughly $69 \mathrm{PuO}_{2} \mathrm{~F}_{3}^{-}$and $31 \mathrm{PuO}_{2}^{2+}$. This is appcoximately

equivalent to the ratio that might be predicted based solely on the results of the soil adsorption ( $\left.K_{d}\right)$ tests, in which 25 of the soluble plutonium in all oxidation states was not adsorbed. If all of the non-adsorbed plutonium in the soil adsorption experiment is assumed to have been Pu(VI), then roughly 638 (258/408 of the total plutonium in the original water sample) of the pu(VI) could have been in the form of anionic fluoride complexes.

The apparent discrepancy between the results of the soil adsorption tests and the ion exchange tests may be accounted for by examining the experimental method. As the equations for the formation constants show, the fraction of Pu(VI) in a solution as the anionic fluoride complex exhibits a third and even a fourth order dependence on the free fluoride concentration. The addition of acidic cation exchange resin to a sample of natural well water would have lowered the $\mathrm{pH}$ of the solution to less than 2.5 , reducing BETAF by a factor of almost 20 (see Figure 7 ). If fluoride were present, consumption of free fluoride would easily explain why 968 of the total plutonium was adsorbed by the cation exchange resin instead of the 758 that was adsorbed by the less acidic soil. Additional tests with cation exchange resin that had been pre-equilibrated with an aliquot of the same well water sample would test that hypothesis.

The anion exchange resin adsorption test would also be expected to yield a poor recovery of a plutonium fluoride complex ( $\mathrm{PUO}_{2} \mathrm{~F}_{3}^{-}$) because the complexing anion, $\mathrm{F}^{-}$, would be consumed by the resin. Any of the complex that was initially adsorbed by the anion exchange res in would have exchanged, reversibly, with chloride. However, as the resin equilibrated with the water sample, the fluoride activity of the solution would have decreased to the point that the plutonium fluoride complex would dissociate rapidly in the process of exchange with the free chloride in solution. Even with an adsorption selectivity coefficient of 20 for chloride/fluoride, 43 the reduction of fluoride activity in the solution would be greater than 998 under the reported experimental conditions. Pre-equilibration of the resin with an aliquot of the sample using a column arrangement is probably the easiest way to assure that the resin does not affect the sample.

In making these calculations, it was assumed that the well water composition (well $\mathrm{C}-17$ was used) has not changed substantially with respect to fluoride, chloride, and pH. In 
attempting to analyze the data on well $=-17$, as reported hera and in refarence 39, it should also be men:iored that a significant

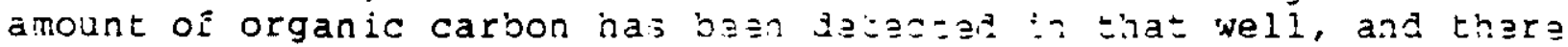
is reason to believe that it could be a complexant/diluent combination, specifically TBP/ultrasene (see Operations istory section). This would be expected to influence the overall behavior of plutonium in the local environment, but it would not directly affect the behavior of $\mathrm{Pu}(\mathrm{VI})$. However, if a significant fractior. of the non-adsorbed plutonium was in lower oxidation states, as wa: probably the case, the dissolved amount of Pu(VI) in the form of an anionic fluoride complex would be lower. The conclusions about $\mathrm{Pu}$ (VI) that are based on thermodynamic calculations would remain unchanged, but the mechanisms responsible for mobilizing the less oxidized plutonium (e. g., organic complexation) would as sume relatively greater importance.

In spite of the complexes just described, plutonium distribution coefficients ( $K_{d}$ 's) on soil are commonly on the order of 10,000 , because the lower oxidation states of plutonium tend to dominate most systems 13 These species are extremely insoluble at normal groundwater $\mathrm{pH}$ 's and are also quite readily adsorbed on virtually all soils. Pu(VI), the only plutonium species that reacts to form anionic fluoride complexes, is relatively unstable in the environment. It only exists in strongly oxdizing solutions, in concentrated plutonium solutions (as a result of the disproportionation of $\mathrm{Pu}$ (IV), or in extremely dilute quantities. Otherwise, it is dominated by $P u(V)$ in oxidized systems 37 and $\mathrm{Pu}$ (III) and (IV) in reducing or "anoxic" stystems (see oxidation-Reduction Potential).

At the highest fluoride concentrations that have been observed in the groundwater wells $(0.8 \mathrm{ppm}) \mathrm{Pu}(\mathrm{VI})$ would move with the groundwater until it was reduced to a lower oxidation state or until the fluoride concentration dropped back to normal. However, no plutonium has been detected recently in any of the monitoring wells that contain $F^{-}$. Also, well C-l7 no longer contains measurable plutonium activity. At present, there is not more than $4 \mathrm{pCi} / \mathrm{L}$ of Pu-239 (see Radiochemical Summary) in any one well. Even the rapid migration of this amount of activity would merely serve to disperse plutonium concentrations to below the limits of detectability, as they are already below the EPA drinking water standard. 24

\section{Chloride}

Except for its function as a counterion for cations in solution, chloride does not specifically affect the migration of any of the major radionuclides. None of the elements that form strong (anionic) chloride complexes (e.g. $\mathrm{Hg}, \mathrm{Zr}, \mathrm{Pb}, \mathrm{Sn}, \mathrm{Bi}$ ) has a radioisotope that is of significance in Low-Level Waste Management. 
However, high levels of chloride in the groundwater are a clear indication that salts feom lise vasta trenches are affecting the chemistry of the gesintigter.

The mean chloride concentration was approximately $8.1 \mathrm{ppm}$, the median value, $3.8 \mathrm{ppm}$. The five wells with the highest chloride concentrations are listed in Table El. At least one of the wells, I-13, is significantly out of lin?, indicating the influence of chemicals from the low-level waste trenches above. High ionic strength, as inferred by a high chloride concentration, tends to enhance the mobility of strontium and cesium and any other radionuclides that are normally immobilized by ion exchange with the soil.

\section{Nitrate}

Nitrate is generally a weaker complexing ligand than chloride. It is relatively easy to reduce in acid solutions and is consumed rapidly by biological activity in the environment. At high concentrations, nitrate forms insoluble salts with the alkaline earths $N p$ ( $V$ ) and others, but the dissociation constants of these salts are all too great to be of significance in environmental modeling.

As was the case for high chloride concentrations, high concentrations of nitrate in the groundwater are indicative of a source of chemical contamination nearby. However, since some of the nitrate sources, (e.g. anion exchange resin, neutralized acid nitrate waste) contain plutonium, it is important to identify the migration paths of this anion. The mean nitrate concentration in all wells was $10.0 \mathrm{ppm}$; the median was $10.5 \mathrm{ppm}$. The highest nitrate concentration measured was $28 \mathrm{ppm}$ (well I-15), which was just within three standard deviations of the mean.

\section{Sulfate}

In many cases sulfate tends to be a stronger complexing ligand than nitrate. It also forms moderately soluble salts (ksp $\mathrm{SrSO}_{4}=$ 10-2.55, with the alkaline earths and other ions. But again, the solubility of these compounds does not limit the mobility of radionuclides in a low-level waste environment. Anionic sulfate complexes can be formed with nickel and neptunium, but the sulfate concentration in the groundwater was far too low for these to be favorable. The calculated ratio of $\mathrm{Ni}\left(\mathrm{SO}_{4}\right)_{2} 2-/ \mathrm{Ni}^{2+}$ was $1.4 \times 10^{-5}$ at $111 \mathrm{ppm}$, the highest sulfate concentration measured. The ratio

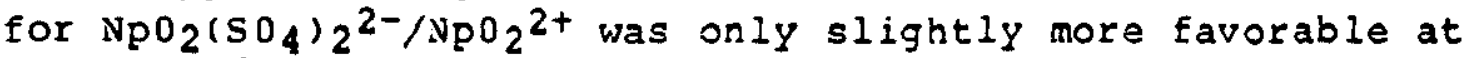
$7.8 \times 10^{-4}$. 
The most imoortan e elfect of the sulfate anion at theso concentrations say he ito tendency to reduce the hydralysia of

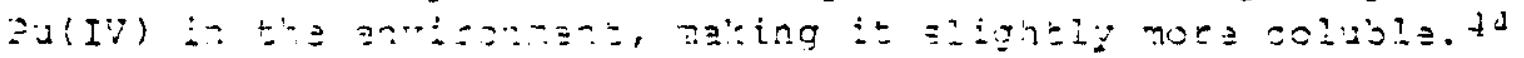

\section{Phosphate}

The radionuclides most affected by phosphate are uranium and plutonium.28,3l Uranium is not widely prevalent in the low-level burial ground, although low concentrations occur naturally there, so it will not be considered in this discussion. A few wells were found to contain phosphate at measurable concentrations but none of these were located where plutonium contamination was likely to be present. Plutonium reacts extensively with phosphate and probably forms mobile, anionic complexes of $\mathrm{Pu}$ (IV) in the environment. The limiting factors in the formation of these complexes are the concentration of free $\mathrm{HPO}_{4}{ }^{2-}$, and the amount of free plutonium available. The thermodynamic data quoted by Benson and Teague 28 and the stability constants quoted by cleveland 34 indicate that the formation of anionic phosphate complexes is highly favored, even under environmental conditions. below:

Relevant equations ware calculated, and the results are given

\section{Compley. Disscciation Constants}

log $\mathrm{K}$

$$
\begin{aligned}
& \mathrm{Pu}\left(\mathrm{HPO}_{4}\right)^{2+}=\mathrm{Pu}^{4+}+\mathrm{H}^{+}+\mathrm{PO}_{4}^{3-} \\
& \mathrm{Pu}\left(\mathrm{HPO}_{4}\right)_{2}^{(\mathrm{s})}=\mathrm{Pu}^{4+}+2 \mathrm{H}^{+}+2 \mathrm{PO}_{4}^{3-} \\
& \mathrm{Pu}\left(\mathrm{HPO}_{4}\right)^{2-}=\mathrm{Fu}^{4+}+3 \mathrm{H}^{+}+32 \mathrm{O}_{4}^{3-} \\
&{\mathrm{Pu}\left(\mathrm{HPO}_{4}\right)_{4}^{4-}}^{4-} \mathrm{Pu}^{4+}+4 \mathrm{H}^{+}+4 \mathrm{PO}_{4}^{3-}
\end{aligned}
$$

Acid Dissociation Constants

$\underline{\log K}$

$$
\begin{aligned}
& \mathrm{HPO}{ }_{4}^{2-}=\mathrm{H}^{+}+\mathrm{PO}_{4}^{3-} \\
& \mathrm{H}_{2} \mathrm{PO}_{4}^{-}=\mathrm{H}^{+}+\mathrm{HPO}_{4}^{2-} \\
& \mathrm{H}_{3} \mathrm{PO}_{4}=\mathrm{H}^{+}+\mathrm{H}_{2} \mathrm{PO}_{4}^{-}
\end{aligned}
$$

$-2.1$ 


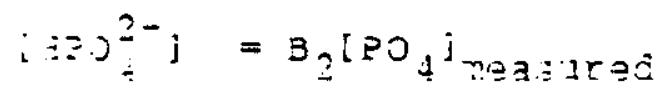

$$
\begin{aligned}
& \mathrm{s}_{2}=\frac{\left[\mathrm{HPO}_{4}^{2-}\right]}{\left[\mathrm{H}_{3} \mathrm{PO}_{4}\right]+\left[\mathrm{H}_{2} \mathrm{PO}_{4}^{-}\right]+\left[\mathrm{HPO}_{4}{ }^{2-}\right]+\left[\mathrm{PO}_{4}^{3-}\right]} \\
& \frac{1}{B_{2}}=\frac{\left[\mathrm{H}^{+}\right]^{2}}{\mathrm{~K}_{1} \mathrm{~K}_{2}}+\frac{\left[\mathrm{H}^{+}\right]}{\mathrm{K}_{2}}+1+\mathrm{K}_{3}\left[\mathrm{H}^{+}\right]
\end{aligned}
$$

$\log K$

$$
\mathrm{Pu}\left(\mathrm{GPO}_{4}\right)_{3} 2-=3 \mathrm{Pu}_{4}^{4+}+
$$

$$
\mathrm{Pu}\left(\mathrm{HPO}_{4}\right)_{4}^{4-}=\mathrm{Pu} 4++4 \mathrm{HPO}_{4}{ }^{2-}
$$

$\frac{\left[P L\left(A P O_{4}\right)_{3}^{2-}\right]}{[P L(I V)]}=\frac{\left[\mathrm{HPO}_{4} 2-\right]^{3}}{10^{-33.4}}=2.5 \times 10^{33}\left(\mathrm{~B}_{2}\left[\mathrm{PO}_{4}\right]_{\text {measure }}\right)^{3}$

$$
\text { At pl j.j ( } \left.32=1.9 \times 10^{-2}\right) \text { and the highest phosphate }
$$

concentration measured $\left(5.9 \times 10^{-5} \mathrm{M}\right)$, the divalent phosphate complex is favored by $3.5 \times 10^{15}$. At the mean phosphate concentration ( 0.5 pom as $D$ ) this ratio is reduced to $8.1 \times 10^{2} 3$, but the divalent anionic complex is still highly favored. The tetraphosphate complex is favored even more (see table 3 ).

$$
\frac{\left(\mathrm{PU}\left(\mathrm{HPO}_{4}\right)^{4-}\right]}{\left[\mathrm{Pu}{ }^{4+}\right]}=10^{43.0}\left(\mathrm{~B}_{2}\left[\mathrm{PO}_{4}\right]_{\text {measured }}^{4}\right.
$$

$$
=1.6 \times 10^{19} \quad \begin{aligned}
& \text { at } \mathrm{pH} 5.5 \text { and } 1.8 \mathrm{ppm} P\left(5.8 \times 10^{-5 \mathrm{M}}\right. \\
& \text { phosphate })
\end{aligned}
$$

and

$$
=9.5 \times 10^{16} \text { at } \mathrm{pH} 5.5 \text { and } 0.5 \mathrm{ppm} \mathrm{p}
$$




\section{TABLE 3}

\begin{tabular}{|c|c|c|c|c|c|}
\hline \multicolumn{6}{|c|}{$\begin{array}{l}\text { ANION/CATION SPECIATION RATIOS* } \\
\text { FOR PU (IV) WITH PHOSPHATE } \\
\end{array}$} \\
\hline \multirow[t]{2}{*}{ CASE } & $\mathrm{pH}$ & {$\left[\mathrm{PO}_{4}\right]_{T}$} & BETAP & {$\left[\mathrm{P} \cup\left(\mathrm{HPO}_{4}\right)_{3}^{2-}\right]$} & {$\left[\mathrm{Pu}\left(\mathrm{HPO}_{4}\right)_{4}^{4-}\right]$} \\
\hline & & & & {$\left[\mathrm{Pu}^{4+}\right]$} & {$\left[P u^{4+}\right]$} \\
\hline AVERAGE & 5.32 & $2.2 \times 10^{-6}$ & $1.30 \times 10^{-2}$ & $5.8 \times 10^{10}$ & $6.7 \times 10^{12}$ \\
\hline $\begin{array}{l}\text { WORST } \\
\text { REAL }\end{array}$ & 5.50 & $5.8 \times 10^{-5}$ & $1.96 \times 10^{-2}$ & $3.5 \times 10^{15}$ & $1.6 \times 10^{19}$ \\
\hline $\begin{array}{l}\text { HIGH } \\
\text { PHOSPHATE }\end{array}$ & 5.50 & $5.0 \times 10^{-4}$ & $1.96 \times 10^{-2}$ & $2.4 \times 10^{18}$ & $9.2 \times 10^{22}$ \\
\hline
\end{tabular}

* At Thermodynamic Equilibrium

$\left[\mathrm{PO}_{4}\right]_{\mathrm{T}}$ Represents total phosphate in solution in moles/liter 
These calculations indicate that the anionic phosphate complexes of Pu(IV) are highly favored, even at very low phosphase concentrations. These relationships are described in terms of

$\mathrm{Pu}$ (IV) concentration, which is normally soluble only to $7 \times 10^{-22} \mathrm{M}$ at $\mathrm{pH} 5.5$ without complexation. However, even the average phosphate concentration ( $0.5 \mathrm{ppm}$ measured as phosphorus) would result in an equilibrium concentration of anionic plutonium of $5.7 \times 10^{-8} \mathrm{M}$ tying up only 1.48 of the total phosphate. This would represent a limit of $848 \mathrm{nCi} / \mathrm{L}$ of pu-239 (based purely on solubility considerations).

Away from any solid plutonium source, and in the presence of normal burial ground soil, the steady state would be shifted by a factor of $10^{3}$ (a conservative value of $\mathrm{Kd}$ for Pu4t) decreasing the activity of the anionic plutonium to a maximum of about $1000 \mathrm{pCi} / \mathrm{L}$ of $\mathrm{Pu}(\mathrm{IV})$. This shows that while the complexing effects of phosphate are very important in terms of radionuclide transport, the amount of activity that could be mobilized by normal amounts of phosphate is fairly small. This statement is further supported by the phosphate analyses which show that phosphate is virtually non-existent in most of the groundwater beneath the lo'w-level waste trenches.

Two wells, E-5 and E-17, were found to be contaminated with a phosphorus containing compound in 1981. The preliminary analysis was done by Inductively Coupled Plasma Emission Spectroscopy, and the concentrations were 13-15 ppm phosphorus. However, no phosphate was detectable by anion chromatography, indicating that these wells were probably contaminated by a TBP solvent spill that occurred around that area in 1971. Subsequent analyses performed in June 1982, were unable to detect phosphorus in either well. This illustrates the importance of obtaining a profile of the organic compounds in the groundwater also.

Summarizing, just the appearance of phosphate in any of the monitoring wells is an anomolous event. The median phosphate concentration was below the detection limit, and 908 of the wells contained less than $0.07 \mathrm{ppm}$ of phosphorus. The effect of phosphate on radionuclide migration around the SRP burial ground should be minimal as long as these low concentrations do not increase by more than an order of magnitude.

\section{Silicate}

Dissolved silicates appear to have very little affect on radionuclide mobility at SRP. At the normal groundwater pir, 
dissolved silicates are largely in the form of hydrated silica $\mathrm{SiO}_{2} \cdot 2 \mathrm{H}_{2} \mathrm{O}$, or in common notation, $\mathrm{H}_{4} \mathrm{SiO} 4$. Polymeric forms

of silica, especially metasilicates, ar? also prevalent, but silica is considered hydrolyzed for the purpose of simple equilibrium calculations. In systems that are more acidic than about $\mathrm{pH} 10$, dissolved silica has virtually no complexing strength. 45 At high $\mathrm{pH}$, silicates tend to hydrolyze, and react weakly with most cations, including sodium, aluminium, potassium, strontium, and possibly cesium. These complexes are weak and generally unimportant, especially since none of the $643^{-G}$ wells are alkaline.

\section{Competing Cations}

\section{Sodium}

Chemically, sodium affects radionuclide migration by simply raising the ionic strength of the aqueous system. This tends to make some salts less soluble, but only a few radionuclides are affected by solubility considerations, and these tend to be influenced far more strongly by the complexation strength of the counterions (anions). The major effect of excessive sodium is to enhance the mobility of cationic radionuclides by competing with them for ion exchange sites on the soil.

The highest sodium concentrations were on the order of 0.5 to 5 percent of the total ion exchange capacity that would normally be in the surrounding soil (dry bulk density 2.0, porosity 0.25 , ion exchange capacity $0.5 \mathrm{meq} / \mathrm{l} 00 \mathrm{~g})$. This is not significantly large with respect to the normal calcium concentration because of the disparity in their relative soil affinities. Spaldingl6 found the calcium selectivity with respect to sodium to be roughly $10^{3}$ for soils derived from Conasauga shale (montmorillinite and kaolinite) at pH 5. Prout's datal3,46 can be analyzed to obtain a strontium/sodium selectivity of roughly 180 for Savannah River Plant soil (208 clay) at $\mathrm{pH}$ 5. Therefore, calcium concentration tends to be more important than sodium concentration in its effect on radionuclide retention where simple ion exchange with the soil is involved (eg.., Sr-90, Co-60, etc.).

High concentrations of sodium have long been known to cause clay soils such as those at 643-G, to swell, thus decreasing their permeability to water. At moderately low concentrations, however, sodium may compete for adsorption sites on the soil, thus enhancing radionuclide migration. Two important radionuclides that would be affected are $\mathrm{Sr}-90$ and $\mathrm{Cs}-137$, both of which are normally adsorbed by an ion exchange mechanism.19,47 Cesium is generally adsorbed 
irreversibly on clays, but sodium or potassium colid compete somewhat for adsorption sitesly. High concentrations of cations also tend to shift the oi $3 t$ which the soil is electrically neldtra! (zero point of charge) to more alkaline (higher) values. This reduces or even reverses the electrostatic driving force for cation adsorption by the soil. This may have the effect of making the kinetics of adsorption slower, and permitting greater transport distances, especially for site-specific cations such as cesium. Cesium is adsorbed irreversibly on kaolinite once it contacts the proper adsorption site, but it can be easily dislodged from less specific exchange sites by other cations.

The statistics of the sodium data are summarized in Table D9. The median concentration $(5.6 \mathrm{ppm})$ is slightly below the mean ( $8.3 \mathrm{ppm})$, and all but one of the wells (I-13) are within three standard deviations of the mean. Well I-13 had about 40 ppm of sodium, and four other wells contained $30 \mathrm{ppm}$ or more. Excessive sodium would be expected to enhance the mobility of Cs-137, Sr-90, and $R u-106$ as well as any other radionuclides that are cationic and not strongly complexed. There is no definite threshold for these effects, but they tend to be nearly additive. That is, solutions of high ionic strength are generaliy better at mobilizing cations, even when there are several different species involved.

\section{Potassium}

Potassium, like sodium, can only affect the migration of radionuclides by the mechanism of competing for ion exchange sites on the soil. As with sodium, elevated potassium concentrations in the groundwater are an indication that chemical and possibly radioactive - contamination has migrated from the trenches. Potassium, with its smaller (unhydrated) volume might be expected to compete somewhat better with cesium for adsorption sites on the soil than does sodium. More recent work with SRP trench water and soil samples tends to support this theory, 49 but it is not necessarily confirmed in the literature. 19

One extreme outlier ( $I-13)$ was identified among the groundwater wells. This well contained more than 50 times the median potassium concentration. A re-calculation of the overall data distribution without this well reduced the mean from 3.97 to 2.21 ppm. With the possible exception of Cs-137, which may be more affected, high potassium concentrations are roughly equivalent to high sodium with respect to radionuclide mobilization.

\section{Calcium}

Calcium is important to radionuclide migration, especially with respect to $\mathrm{sr}-90$. It competes with strontium for ion exchange 
sites on the soil to the extent that there is virtually no selectivity between them. 16 This means that where calcium exists in solution, strontium will also, and their exchange ratios vith the soil (Kd's) will be about the same.

Calcium also affects the formation of complexes by competing for complexing ligands. This tends to be beneficial, especially in cases where polydentate ligands like EDTA may be present. For example, even though EDTA could form a strong, mobile complex with sr-90, calcium in the environment competes so strongly that an excess of EDTA-to-calcium would be required to affect the mobility of the strontium at all. The calcium-EDTA complex is more than one hundred times stronger than the strontium-EDTA complex. 42 Unfortunately, this competition for EDTA doesn't really help in the case of plutonium, which complexes with EDTA considerably more strongly than does calcium. 34

There was a wide range of calcium concentrations in the monitoring wells, but calcium was universally detectable. At least two values $(C-5$ and $A-5)$ were more than three standard deviations from the mean, but this is not necessarily an indication of groundwater contamination. The mineralogy of the region around the burial ground includes calcareous deposits, which often cause calcium concentrations in nearby groundwater to reach $100 \mathrm{ppm}$ or more. A sampling of wells in the area around the burial ground confirmed the existence of some locally high concentrations of natural calcium.

\section{Barium, Strontium}

Because they are usually present at such low concentrations, barium and strontium do not normally contribute significantly to the groundwater chemistry of the burial ground region. At subsaturated concentrations they simply provide more competition in cation exchange processes. However, the observation of 21 ppm of barium in well $I-13$ proves that at least one of the nearby trenches is contaminating the groundwater.

In spite of the status of its isotope (sr-90), strontium is no more important to radionuclide migration than barium. It is just naturally swamped out by calcium, and their chemical similarity makes consideration of the far less concentrated strontium unncessary. Except for the purpose of modelling strontium in the environment, or for tracing unusual sources of contamination, the concentration of strontium in these wells is of small importance.

\section{Iron}

Iron plays an extremely important part in radionuclide migration. Its oxides and, to a lesser extent, those of manganese, 
are considered to be two of the major adsorption substrates for the immobilization of radionuclides on sandy soils. 48 the presence of iron in the jroundwater is also strong evidence of the influence 0 a nearby waste disposal site, or soine other source of chenically reducing or strongly complexing contamination.

At the $\mathrm{pH}$ of the groundwater monitoring wells, iron is solutle only as Fe(II), Fe(III) being soluble to only about $80 \mathrm{ppb}$ at pH 4 . Therefore, groundwaters that contain iron concentrations in excess of about $0.1 \mathrm{ppm}$ and are not overly acidic must be either strongly reducing or strongly complexing. Any of these properties can

enhance the mobility of several radionuclides.15 Recent work with SRP soils and water from the burial trenches indicates there is an inverse correlation between iron in the trenches and the distribution coefficient $\left(R_{d}\right)$ of strontium.

Wells that are suspected of being contaminated because of their high iron concentrations include G-21, G-7, and C-19. Wells $I-1, G-9, G-30$ and $C-5$ are also considered high, even though they are all less than 1 ppm in iron.

\section{Magnesium}

Magnesium is another cationic species that contributes to the total ionic strength of the natural groundwater. Like calcium, it is a chemical analog of strontium, and they can be considered together in predicting their effect on strontium migration.

The average magnesium concentration in the groundwater wells was $1.6 \mathrm{ppm}$, but excluding well $\mathrm{G}-7$, which was $39.9 \mathrm{ppm}$ in magnesium, all of the other wells were within three standard deviations of the mean.

\section{CONCLUSIONS}

\section{Burial Ground Performance}

The Low Level Waste Burial Ground at the Savannah River Plant (SRP) is operating well within the guidelines set by the Department of Energy for such facilities. Furthermore, the results of this extensive monitoring survey prove that the wate buried there doas not pose a threat to the environment through groundwater 


\section{E. L. ALBENESIUS}

contamination. With the exception of tritium, $*$ the radioactiviz: levels in 63 out of the 66 grcundwater monitsring wells ace $23: \cdots$ arinking water standards (EPA standaras bas $3 d$ on 4 mzen oypo: Ref 24).

The anthropogenic activity on the sediments of the monitor:.: wells was also much less than the natural background from uran: $: .$. and thorium decay products in the soil.

In addition to the radiochemical determinations, the groundwater survey detected seven wells that exceeded EPA drinking water standards for hazardous but non-radioactive chemicals. 24 These include two wells that exceeded the $1.0 \mathrm{ppm}$ drinking water standard for barium and five that exceeded the $0.3 \mathrm{ppm}$ standard for iron. No other chemical pollutants were detected at significant levels.

\section{Long-Term Radionuclide Migration from Waste Trenches}

A study was also performed on wells screened at the base of the waste trenches. 49 of the twenty-four trench wells in the SRP burial ground, only seven contained perched water. These were analyzed for the same chemical parameters as in this study. Batch. distribution coefficients were also determined for Sr -85 and Cs -137 with well-characterized soil taken from the burial ground.

The results of this study prove that, as anticipated, "perched" water in the trenches has greater ionic strength and is more reducing than the water in most of the groundwater monitoring wells. Furthermore, the distribution coefficients of $\mathrm{Sr}-85$ and cs-137 on burial ground soil were generally lower with trench water than they were with groundwater. As a result, these isotopes woula move more slowly as they reached the groundwater.

The opposite is probably true for long-lived plutonium isotopes, at least in the absence of strong organic complexants (EDTA, DTPA, etc.). The reducing environment of the trenches favors plutonium (IV), and plutonium (III), which are highly insoluble at near neutral $\mathrm{pH}$ and very strongly retained by soil $\left(\mathrm{K}_{\mathrm{d}}=10^{3}-10^{4}\right)$. Therefore, the predominant tendency of plutonium is to remain stationary. Any traces of plutonium that eventually reach the groundwater environment would gradually disperse, because the higher oxidation potential of the groundwater would permit some conversion to $\mathrm{Pu}(\mathrm{V})$, with extremely small fractions $\left(7.2 \times 10^{-6}\right.$ at $\left.E_{\mathrm{H}}=600 \mathrm{mV}\right)$ of $\mathrm{Pu}$ (VI). The traces of $\mathrm{Pu}$ (VI) would then be transported as the hydroxycarbonate

* The behavior of tritium in the groundwater at SRP is known extremely well and is described by $J$. W. Fenimore in Reference 3 . 
in concentrations that would probably be too small to isajure without preconcentration.

The process described above should operate aj a $\therefore$. . : o of dispersing long-lived plutonium isotopes that reach $t: a$ rat table. However, the amount of plutonium that actualiy saches the water table has been, and will continue to be, linis:c by the quantity of available complexant as well as the amoint s: plutonium in the waste. Therefore, the concentration of plutori $20.3:$ the water table will gradually diminish over the long term, is the soluble complexants are leached away and the less soluble plutonium is left behind in the trenches.

A secondary increase in the rate of plutonium transport might be postulated to occur later, after the (organic) waste degradation products leach away and the trenches become more oxidizing. However, even relatively oxidizing rainwater would not favor migration unless a complexant anion was available to mobilize Pu (IV). Acidic rainfall would keep the plutonium in the $P u$ (III) and (IV) states, and any plutonium that became oxidized would most likely remain as Pu (V). Only very small fractions of the total would be ever free to move as $\mathrm{PuO}_{2}\left(\mathrm{CO}_{3}\right) \mathrm{OH}^{-}$.

The most important mechanisms by which the waste in the SRP burial ground could contribute to the population dosa would be through fairly direct pathways, such as plant uptake, intrusion, and erosion. 50 The radionuclides with moderate half-lives (less than 100 years) will have decayed away long before they reach the perimeter of the burial ground, let alone the nearest groundwater outcrop, a third of a mile away. Radionuclides in this class include $\mathrm{Cs}-137, \mathrm{Sr}-90, \mathrm{Co}-60, \mathrm{Ni}-63, \mathrm{Pu}-238$, and others. Others, like I-129 and Tc-99, will be around for extremely long periods of time but in very ailute concentrations.

Pu-239, with its poor mobility and long half-life, will be gradually dispersed by the mechanisms described in this paper. However, this dispersion will probably not occur rapidly enough to dominate other mechanisms of transport (e.g. plant uptake, erosion, human intrusion). All of these factors are considered in the models that SRL is using to estimate the potential consequences (dose to any member of the population) of scenarios that may occur as a result of decommissioning the burial ground. 50

\section{RECOMMENDATIONS}

Low-level counting should be performed on all groundwater wells in order to complete the evaluation of the overall performance of the burial ground and to see if low-level activity can be detected in the "suspect" wells as predicted. 
The volume of the gross alpha and non-vola:ile beta-gainna sampling program could be diminished sutsten: $1.11 y$. Yearly or semi-yearly surveys should be suficicient, $\equiv: ;: \cdots$. samples are tested for a few basic cheinizai : : ineters (pi, conductivity, iron and D.O.).

Finally, the wells should be analyzed $E: c$ organic materials that might be capable of complexing plutoniu.. 
E. L. ALBENESIUUS

\section{ACKLIOWLEDGNIENTSS}

The authot gratesuliy actio:- a the contributions of the following geople:
G. A. Carothers
C. J. Coleman
J. W. Fenimore
C. D. Denard
C. พ. Hisu
J. H. Leroy

$\because$ Analysis

I:S Analysis

Dony-tarm Well Monitoring

Ion Chromatography

Carbon Analysis

Low Level Gamma spectrometry Alpha Pulse Height and Plutonium Analys is

W. A. Spencer

Carbon Analysis

P. B. Waters

Sampling, Electrochemical Analysis, and Sample

Preparation

M. B. Wood

Sr-90 Determination 
E. L. ALbenesis:

APPENDIX A

ANALYTICAL METHODS

(INCLUDING TABLE Al) 


\section{APPENDIX A}

\section{Analyses}

Anions $\left(\mathrm{F}^{-}, \mathrm{Cl}^{-}, \mathrm{NC}^{-}, \mathrm{SO}_{4}=\mathrm{HPO}_{4}=\right)$

Anions were des $r_{\pi}$ ined by ion chromatography (IC) with conductivity detection (Dionex, Sunnyvale, $C A$ ). The mobile phase was a caruonatj aizier, so bicarbonate and carbonate could not be measure icy this technique. Samples were Eiltered with $0.45 \mathrm{mic}$ con membrane filters prior to analysis.

Cations $\left(\mathrm{Na}^{+}, \mathrm{K}^{+}, \mathrm{Ca}^{++}, \mathrm{Ba}^{++}, \mathrm{Sr}^{++}, \mathrm{Fe}^{++}, \mathrm{Mg}^{++}\right.$)

Cations were determined by inductively coupled plasma (ICP) and/or atomic absorption spectroscopy (AAS). The methods were in good agreement for the ions $\mathrm{Ca}^{++}, \mathrm{R}^{+}, \mathrm{Na}^{+}$, and $\mathrm{Mg}^{++}$) that were measured with both instruments. Samples were taken in polyethlene, filtered, and then acidified with ultrapure nitric acid prior to analysis.

\section{$\underline{\text { Silica }}$}

Silica was determined by ICP as silicon in filtered and acidified samples. Sowever, the acid spike typically contained more silica than the sample, so this analysis was not precise $( \pm 508)$.

\section{Phosphate}

Phosphate concentrations below 1 ppm were measured by ICP as phosphorus in filtered and acidified samples.

\section{Dissolved Oxygen (DO)}

Oxygen concentrations were determined with a polarographic type (YSI of Model \$57) DO meter, standardized with air. Samples were obtained in glass Do bottles equipped with siphon-type caps. These allowed samples to be taken from below the water surface with minimum turbulence. These samples were also used in oxidation-reduction potential measurements and dissolved carbon measurements. Conductivity was measured with the YSI Model \$33 (probe Model \$3310) standardized with $\mathrm{KCl}$ in distilled water.

pH

pH was measured with a Markson Model \$4403 and Sensorex s200C glass electrode. 


\section{APPENDIX A cont'd}

$\therefore$ : iation-ieauction Potencial

The oxidation-reduction potential of the well water arpias was measured with an Orion platinum electrode (Model $: 95-78$ ) versus the saturated Calomel Electrode (SCE) that is sulit into the electrode. Results are reported with respect $\therefore$ the normal hydrogen electrode (NHE).

Total Carbon (Organic, Inorganic)

The organic carbon dissolved in the groundwater was measured as the difference between the total carbon (TC) and total inorganic carbon (TIC) in each sample. Samples were obtained from the dissolved oxygen sample bottles, and were filtered (Gelman $A E$, glass) prior to analysis. The instrument was a Total Carbon Analyzer (Coulometrics Incorporated, Wheat Ridge, COl. 
TABLE AI - ANALYSIS SENSITIVITY AND PRECISIOI

Reported As

Ion Chromatography

ICP

$A A$
Detection Limit (ppm)

Pracision $(\sigma)$ $(1-5 \mathrm{ppm})$
$\mathrm{F}^{-}$

$\mathrm{CI}^{-}$

$\mathrm{NO}_{3}{ }^{-}$

$\mathrm{SO}_{4}=$

$\mathrm{HPO}_{4}=$

p

$\mathrm{Si}$

$\mathrm{Ca}$

$\mathrm{Ba}$

Sr

Fe

Mg

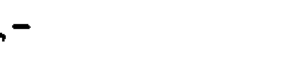

(ppm)

(ppm)

(ppm)

(ppm)

(ppm)

(ppm of $\left.\mathrm{PO}_{4}\right)$

(ppm)

(ppm)

( ppm)

(ppm)

(ppm)

(ppm)

$\begin{array}{ll}N a & (p p m) \\ K & (p p m) \\ C a & (p p m) \\ F \equiv & (p p m)\end{array}$

0.05

$5 \%$

0.05

58

0.5

38

0.5

38

0.5

38

0.060

$<58$

0.030

0.025

0.002

0.001

0.005

0.002

<5

$<58$

<5 하

$<5$ 응

$<5$ 응

$<5$ 응

0.020

0.030

0.050

0.050
$<5$ क

$<5$ 하

$<5$ *

$<58$ 
APPENDIX B

RADIOCHEMICAL DATA

(INCLUDING TABLES BI AND B2) 


\section{RADIOCHEMICAL GROUNDWATER DATA}

Table Bl describes the results of routine radiochemical surveys performed on the groundwater monitoring wells from 1973 through 1980. Units are pCi/L. Dots represent analyses that have not been performed (no data).

The first five headings are low level analyses performed in 1980: Pu-239, pu-238 (with chemical separation), $\mathrm{Cs}-137, \underline{\mathrm{s}-90}$, and $\mathrm{Co}-60$. Zero values were below the routine detection limit for the low-level counting facility at SRL $(<1 \mathrm{pCi} / \mathrm{L}$ of $\mathrm{Pu}-238 / 239 ;<8 \mathrm{pCi} / 1$ of $\mathrm{Cs}-137 / \mathrm{Co}-60 ;<6 \mathrm{pci} / \mathrm{L}$ Sr -90$)$.

The second five headings, YEAR 6 through YEAR 0 represent the gross alpha measurements from 1976 through 1980. YEAR 36M represents the mean of all gross alpha measurements from 1973 through 1976, and Slope 1 is the slope (in $\mathrm{pCi} / \mathrm{L} /$ year) of the data over that time. YEAR $M$ is the average of all gross alpha measurements made on a particular well, from 1973 through 1980. Slope 2 is the slope of the gross alpha measurements from 1976 through 1980.

The variables YEAR 6 BG through YEAR $O$ BG are the non-volatile beta-gamma measurements of the wells from 1976 through 1980. YEAR MBG is the average of all measurements of beta-gamma (non-volatile) for each well, and Slope 2BG is the slope of the beta-gamma analyses ( $\mathrm{pCi/L/Year})$ from 1976 through 1980. 
TAEI,E $\mathbf{D}-1$

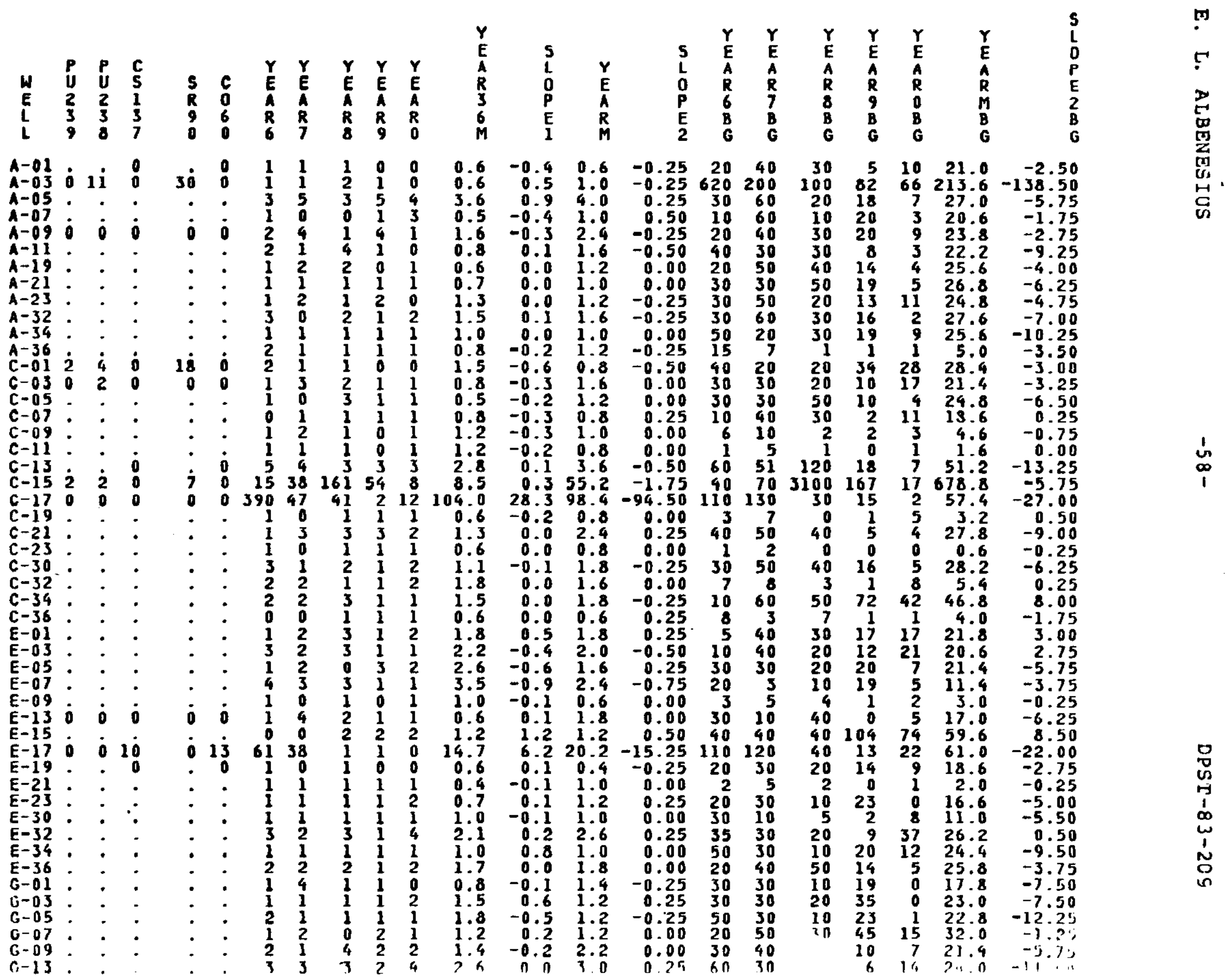




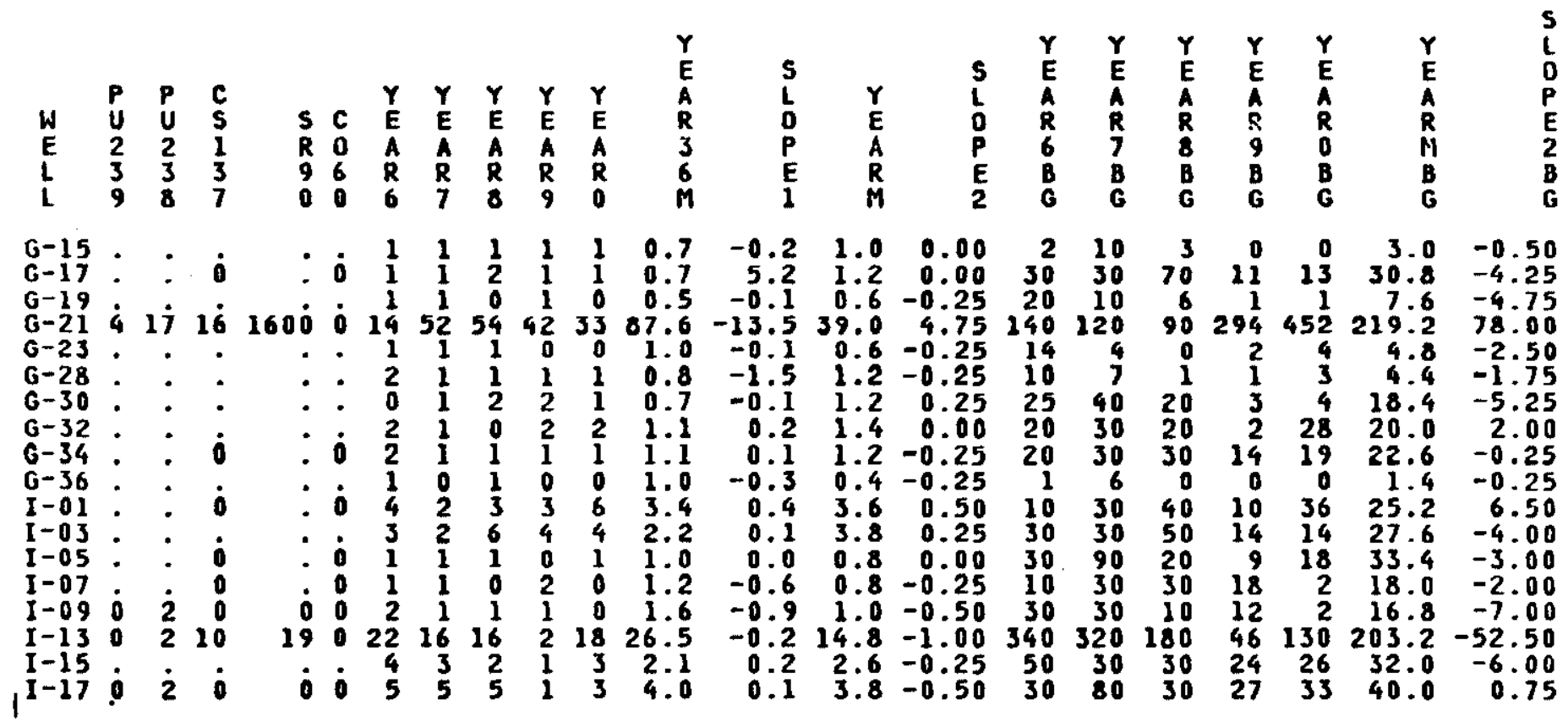


E. L. ALBENESIUS

Iacie B2 is a stacistical summary of che radioctemisal data. Variables are as explained in Table 1 . 
VARIABLE

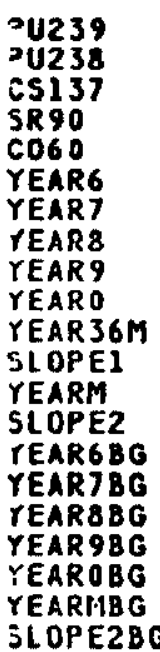

\section{N}

$\begin{array}{rr}12 & 0.66666667 \\ 12 & 3.50000000 \\ 20 & 1.80000000 \\ 12 & 139.50000080 \\ 20 & 0.65000000 \\ 67 & 9.01492537 \\ 67 & 4.26865672 \\ 67 & 5.62686567 \\ 67 & 2.67164179 \\ 67 & 2.35820896 \\ 67 & 4.83582090 \\ 67 & 0.33731343 \\ 67 & 4.78805970 \\ 67 & -1.66417910 \\ 67 & 41.76119403 \\ 67 & 41.98507463 \\ 67 & 73.95522388 \\ 67 & 22.13432836 \\ 67 & 19.88059701 \\ 67 & 39.94328358 \\ 67 & -5.47014925\end{array}$

\section{STALIDARD} DEVIATION

\subsection{9}

. 460.05049130 2.90688837 47.91516889 47.91516889
10.35371707 20.93267405 20.93267405
8.13966729 8.13966729
4.70557855 16.54477581 3.99191743 14.3174773 11.68304199 84.91762310 48.28215447 376.48507688 42.75118128 57.33012387 $89.62285833-0.60000000$

\section{MINIMUM}

0.00000000

0.00000000

0.00000000

0.00000000

0.00000000

0.00000000

0.0000000

0.00000000

0.40000000

$-13.50000000$

0.40000000

$-94.50000000$

1.00000000

2.00000000

0.00000000

0.00000000

0.60000000 $20.99037128-138.50000000$

MAXIMUM
VALUE
4.0000000
17.00000000
16.0000000
1600.0000000
13.0000000
390.0000000
52.0000000
161.0000000
54.0000000
33.0000000
104.0000000
28.3000000
98.4000000
4.7500000
620.0000000
320.0000000
3100.0000000
294.0000000
452.0000000
678.8000000
78.0000000

STD ERROR

0.37605072

1.50504203

132.01462983

0.65000000

5.85376956

1.26490786

2.55733316

0.99441863

0.57487792

2.02126607

0.48769033

1.74915226

10.37433883

5.89860398

45.99497265

5.22288806

7.00398938

10.94917480

2.56438200 ó

13.0000000

286.0000000

377.0000000

179.0000000

158.0000000

324.0000000

22.6000000

320.8000000

$-111.5000000$

2798.0000000

2813.0000000

4955.0000000

1483.0000000

1332.0000000

2676.2000000

$-366.5000000$ 
E. L. ALBENESIUS

APPENDIX C

CHEMICAL DATA

(INCLUDING TABLES CI AND C2) 
Table Cl gives the average value of each chemical parameter for each well. Units are given. See Appendix $A$ for analytical details. 
TABLE Cl - BURIAL_GROUND MON ITORING WELL_ANALYSES ( 1980 -19 9 82 1 )

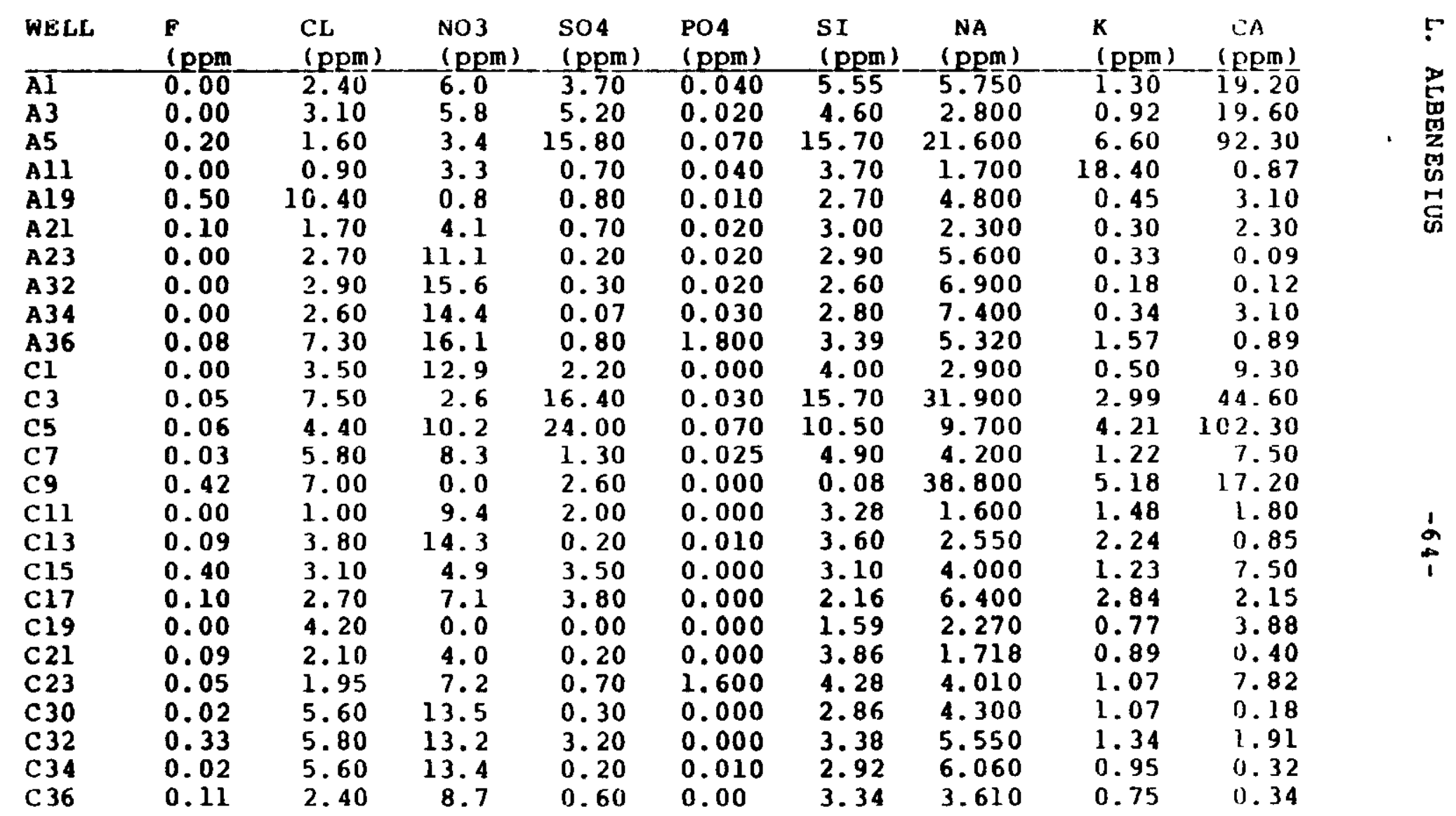


TABLE Cl - BURIAL GROUND MONITORING WELL ANALYSES ( 1980-1982)

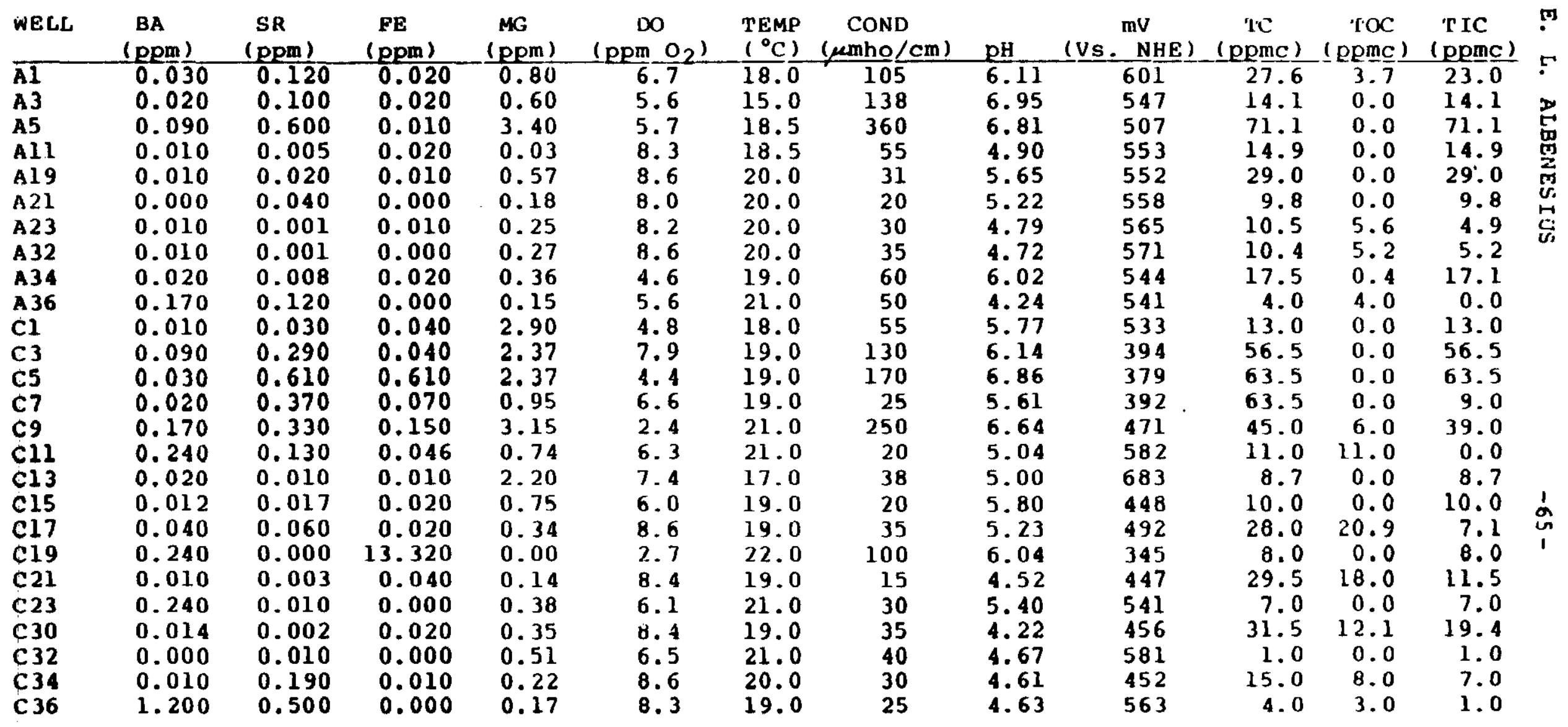


TABLE_Cl - BURIAL_GROUND MONITORING WELL ANALYSES (1980-1982)

\begin{tabular}{|c|c|c|c|c|c|c|c|c|c|}
\hline WELL & $\begin{array}{l}F \\
\text { (ppm) }\end{array}$ & $\begin{array}{c}\mathrm{CL} \\
(\mathrm{ppm})\end{array}$ & $\begin{array}{l}\mathrm{NO}^{3} \\
(\mathrm{p} \mathrm{pm})\end{array}$ & $\begin{array}{l}\text { SO4 } \\
\text { (ppm) }\end{array}$ & $\begin{array}{c}\text { PO4 } \\
(\text { ppm })\end{array}$ & $\begin{array}{c}S I \\
(p p m)\end{array}$ & $\begin{array}{c}\text { NA } \\
(p p m)\end{array}$ & $\begin{array}{c}K \\
(p p m)\end{array}$ & $\begin{array}{c}\mathrm{CA} \\
(\mathrm{ppm})\end{array}$ \\
\hline$\overline{\mathbf{E}} \overline{\mathbf{I}}$ & 0.20 & 2.50 & 2.9 & 3.80 & 0.00 & 3.63 & 4.27 & 1.72 & 32.80 \\
\hline E3 & 0.40 & 2.40 & 8.3 & 1.90 & 0.00 & 3.81 & 4.29 & 2.50 & 42.50 \\
\hline E5 & 0.02 & 9.00 & 14.6 & 1.80 & 15.10 & 6.61 & 7.90 & 3.74 & 8.50 \\
\hline E7 & 0.01 & 4.10 & 16.0 & 0.06 & 0.01 & 3.00 & 2.90 & 1.67 & 1.98 \\
\hline E9 & 0.00 & 4.00 & 16.2 & 0.00 & 0.00 & 5.93 & 4.47 & 1.96 & 19.70 \\
\hline E13 & 0.00 & 1.20 & 7.8 & 0.70 & 0.00 & 4.00 & 2.20 & 0.90 & 1.30 \\
\hline E17 & 0.40 & 3.80 & 10.5 & 111.00 & 13.70 & 5.52 & 30.00 & 10.40 & 56.00 \\
\hline E19 & 0.05 & 5.90 & 13.9 & 5.20 & 0.00 & 6.00 & 10.00 & 1.33 & 29.30 \\
\hline E21 & 0.00 & 2.00 & 10.6 & 1.80 & 0.00 & 3.09 & 4.69 & 1.13 & 0.20 \\
\hline E23 & 0.00 & 3.10 & 8.1 & 1.00 & 0.00 & 2.48 & 4.00 & 1.19 & 0.70 \\
\hline E30 & 0.00 & 3.80 & 16.5 & 1.20 & 0.00 & 3.74 & 6.52 & 0.77 & 1.49 \\
\hline E32 & 0.00 & 9.20 & 25.2 & 0.00 & 0.00 & 4.02 & $7: 97$ & 1.90 & 2.25 \\
\hline E34 & 0.00 & 1.70 & 12.6 & 0.00 & 0.00 & 3.42 & 5.89 & 0.98 & 3.30 \\
\hline E36 & 0.00 & 5.40 & 11.7 & 0.00 & 0.00 & 2.85 & 5.89 & 0.84 & 2.04 \\
\hline Gl & 0.00 & 2.60 & 9.6 & 3.50 & 0.00 & 4.47 & 3.61 & 1.05 & 5.81 \\
\hline G 3 & 0.09 & 7.10 & 13.6 & 2.00 & 0.00 & 4.37 & 4. 24 & 3.17 & 10.30 \\
\hline G5 & 0.14 & 4.20 & 7.1 & 2.90 & 0.00 & 4.88 & 4.57 & 1.27 & 7.94 \\
\hline G7 & 0.00 & 45.00 & 0.1 & 0.50 & 0.00 & 5.18 & 32.20 & 2.80 & 38.60 \\
\hline G9 & 0.10 & 5.20 & 1.2 & 21.00 & 0.00 & 5.71 & 11.00 & 8. 50 & 16.00 \\
\hline G13 & 0.20 & 4.30 & 13.8 & 1.30 & 0.00 & 4.12 & 2.91 & 4.19 & 0.50 \\
\hline G15 & 0.00 & 2.00 & 16.8 & 1.60 & 0.00 & 4.52 & 5.15 & 0.97 & 1.13 \\
\hline G 17 & 0.20 & 4.40 & 11.2 & 1.00 & 0.00 & 2.50 & 14.75 & 0.85 & 0.35 \\
\hline G19 & 0.00 & 3.70 & 5.4 & 3.30 & 0.00 & 3.15 & 4.80 & 2.65 & 4.81 \\
\hline G 21 & 0.00 & 33.00 & 1.5 & 5.40 & 0.00 & 1.64 & 6.00 & 0.97 & 3.30 \\
\hline G23 & 0.10 & 4.40 & 0.5 & 3.70 & 0.00 & 6.38 & 4.30 & 2.82 & 105.00 \\
\hline G 28 & 0.15 & 4.10 & 12.0 & 0.70 & 0.00 & 3.18 & 5.77 & 1.71 & ]. 93 \\
\hline
\end{tabular}


TABLE_C1 - BURIAL_GROUND MONITORING WELL_ANALYSES (1980-1982) (Cont 'd)

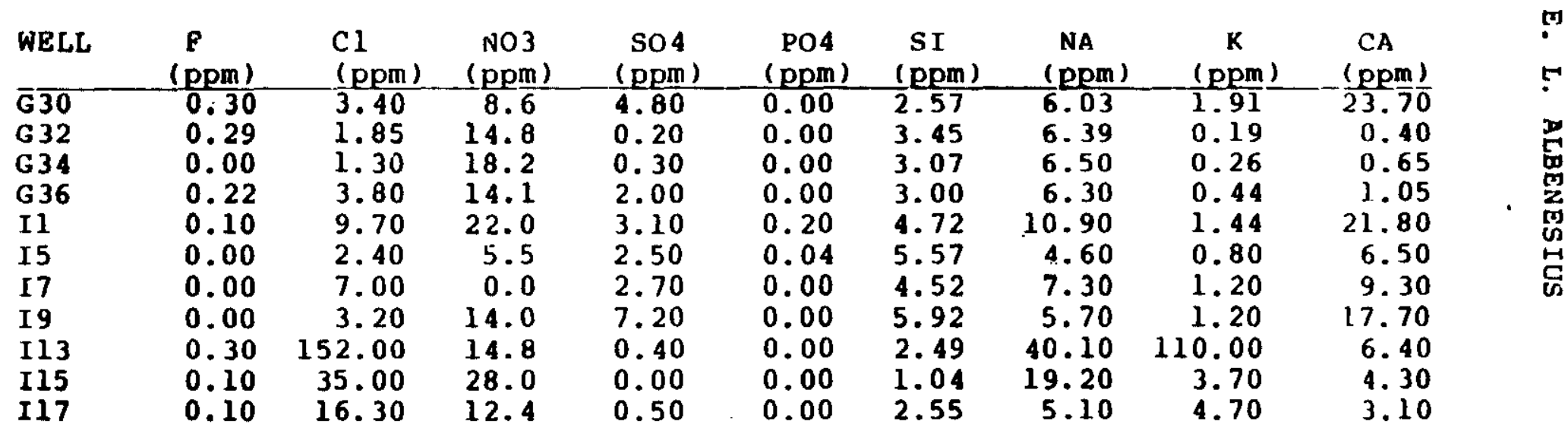


TABLE Cl - BURIAL GROUND MONITORING WELL ANALYSEES (1980-1982)

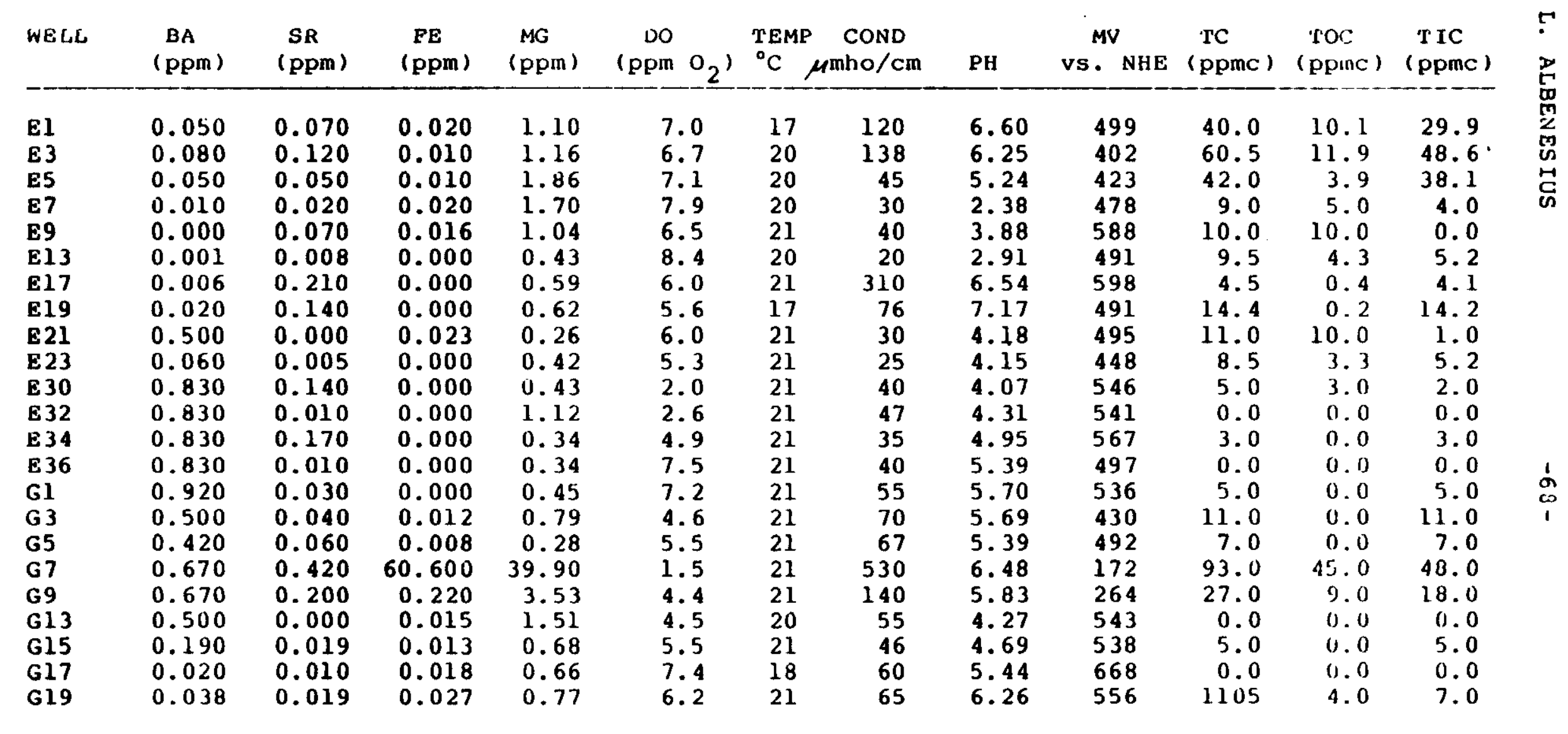


TABLE_Cl - BURIAL GROUND MONITORING WELL ANALYSES ( 1980-1982)

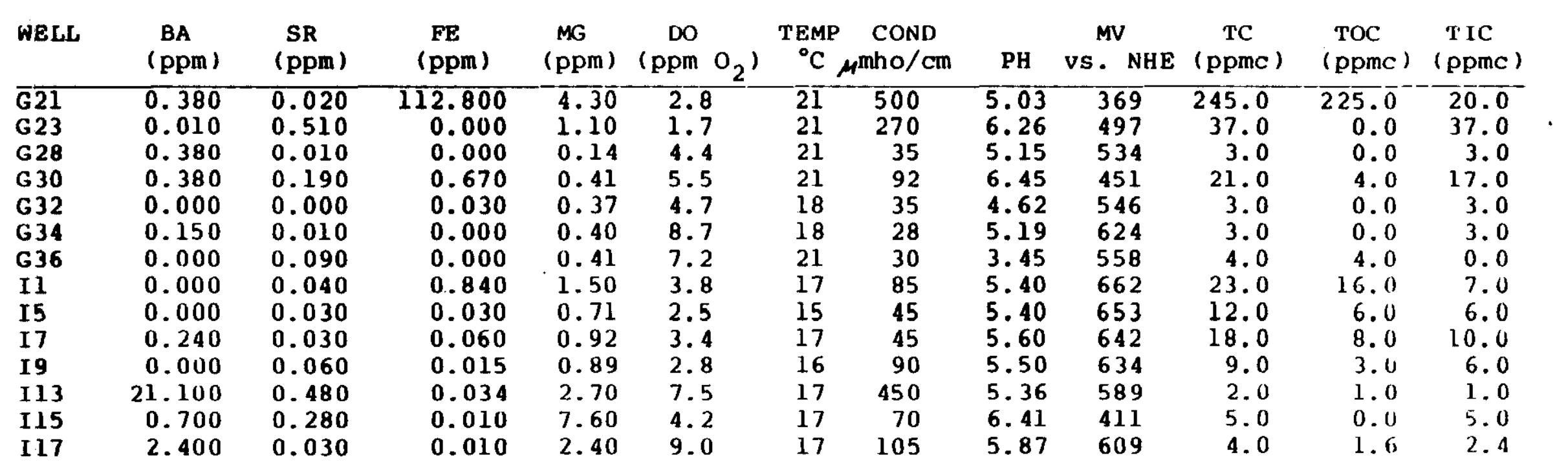


E. L. ALBENESIJS

Table $\underline{\underline{c}} \underline{\underline{a}}$

coinpares cha coefficienc oE variation of the ougrall groungiater cinenistry (C.V. all wells) with that of the individual wells as a function of time (C.V. each 'Ne11).

C.V. all weils is equal to the standard deviation/mean of all 63 well measurements taken together (see also Appendix D).

C.V. each well is the average of the coefficients of variation calculated for multiple analyses of individual wells, consisting of 3 or more measurements. Measurements were mada on separate samples taxen at intervals of $1-10$ months, within one 18-month period. 


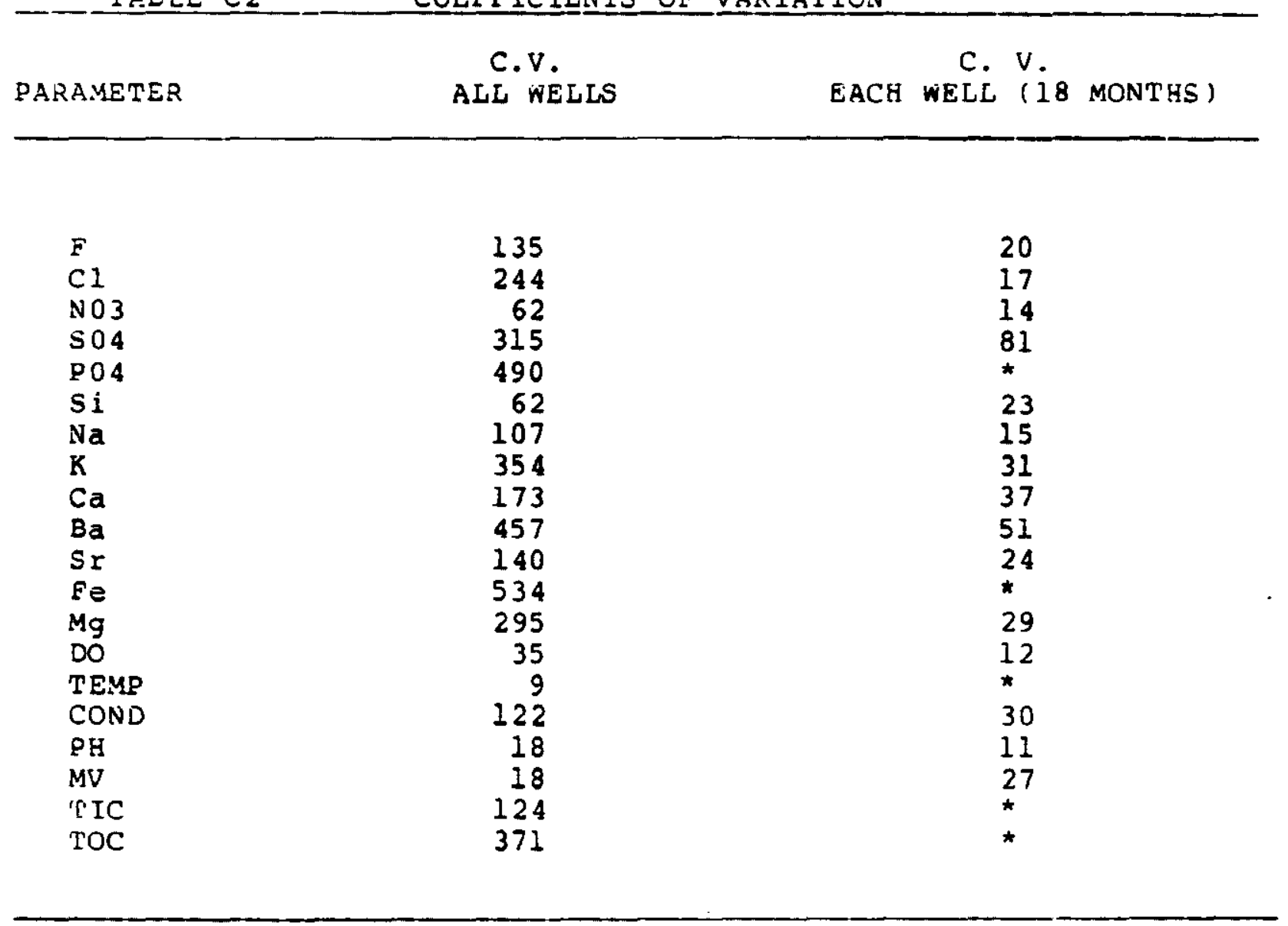

* Insufficient data to estimate C.V. ior this parameter. 
E. L. ALBENESIUS

\section{APPENDIX D}

STATISTICAL SUMMARY CF 643-G GROUNDÁATER CAEMISTRY

(INCLUDING TABLES D1-D22) 
ミะョょisこica? Summary*

Table DI gives the standard statistics for the 63 groundwater monitoring wells. The top part of the table includes all wells, while the bottom part is a modified version derived by excluding observations that more than three standard deviations from the mean of the original data and recalculating the distribution.

$N$ = the number of observations (wells) used in calculating the distribution; other statistical parameters have their usual meanings (e.g., C.V. = coefficient of variance)

Table D2

gives the distribution of all of the groundwater wells, eliminating the zero values for statistical reasons. (This table was provided simply for comparison, since this statistical approach was not used. )

* Please note that the units of each variable are as described in Appendix $C$, generally $\mathrm{mg} / \mathrm{L}$ (ppm). The significant figures qucted in these tables are artifacts of the mathematics of the data analysis and are not meant to imply anything about the precision, which was typically 2 to 3 significant figures, depending on the technique. 
TABLE D-1

AL CW DATA

\begin{tabular}{|c|c|c|}
\hline$\because A R I A B L E$ & H & MEAM \\
\hline 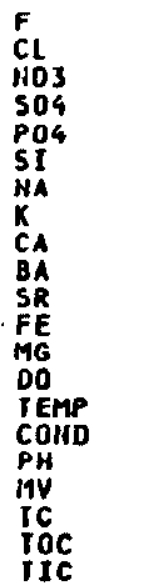 & $\begin{array}{l}63 \\
63 \\
63 \\
63 \\
63 \\
63 \\
63 \\
63 \\
63 \\
63 \\
63 \\
63 \\
63 \\
63 \\
63 \\
63 \\
63 \\
63 \\
63 \\
63 \\
63\end{array}$ & $\begin{array}{r}0.09714286 \\
8.19206349 \\
10.00634921 \\
4.57984127 \\
0.52166667 \\
4.18396825 \\
8.13092063 \\
3.91968254 \\
13.36952381 \\
0.58147619 \\
0.11393651 \\
3.0078889 \\
1.71396825 \\
5.90158730 \\
19.47619048 \\
93.11111111 \\
5.31825397 \\
513.01587302 \\
20.85873016 \\
7.72380952 \\
13.13492063\end{array}$ \\
\hline
\end{tabular}

GH DATA MITH 3-SIGMA VALUES MISSIMO

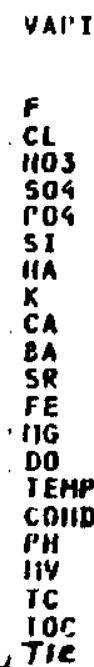

0.12123505

0.0906516

10.00634921

2.86338710

3.80639344

7.10406557

2.20870968

0.25053226

0.09783607

0.26388525

1.71396825

5.90158730

73.1000000

5.36564516

518.51612903
20.85873016

20.21935484
11.35901639
7.79643507
6.18869607
0.330513035

4.73613033

1.57334785

6.65077767

2.83284858

0.40648553

0.13413416

1.70508297

2.05264336

1.71903145

0.90637021

84.47130504

34.63652709

7.20502645
13.20762882
- .00000000

0.90000000

.00006000

.00000000

.00000000

1.60000000

0.18000000

0.00000000

0.00000000

0.00000000

i. 50000000

15.0000900

2.91000000

264.0000008

0.00000000 .006ebes
MAXIMUM

0.50000000

152.00000000

28.00000000

111.00000000

15.10000000

15.7000000

105.00000000

21.10000000

112.80000000

39.90000000

9.00000000

52.00000000

7.17000000

683.00000000

245.00000000

225.00000000
71.10000000
6.4200000

38.0000000

24.00000000

1.80000000

10.50000000

300000

56.00000000

2.40000000

0. 51000000

13.32600008

39.90000000

9.00000000

360.00000000

7.17000000

245.00000000

45.00000000
56.50000000
STD ERROR

0.01648508

1580417

0.77970242

1.81555032

0.32887172

1.09470931

2.90681873

0.33481979

.02423238

0.63657323

0.25792599

0.21657761

4.35207775

11.9032086

4.33859461

3.61827565
2.05875444
SUM

6.120000

516.100000

630.400000

288.530000

263.565000

512.248000

246.940000

842.280000

36.633000

7.178000

89.980000

371.800000

227.000000

366.00000

2350.000000

1314.10000

486.60000

827.500000
VARIANCE

0.017121

323.744049

207.662047

6.522814

6.813866
75.49847

192.323568

532.324492

7.062570

0.025446

258.14355

5.529205

4.191126
2.955069

2976.879552

8926.241679

1135.874398

824.790876
267.023600
STD ERROR

0.01539687

6.99014824

.77970242

0.03223515

.20144655

.85154482

.62493470

0.05162371

0.01717412

.21831350

.2579259

.21657761

01151091

10.7278644

.33859461

.091503927
SUM

5.62009

630.40000

177.530000

77.53500

32.190000

33.348000

42.680000
15.533000

15.533000

16.097000

107.980000

371.800000

4386.000000

332.676000

2148.00000

131.100000

261.600000
692.900008
VARIAHCE

0.0146979

60.7843998

38.2999590

0931356

8.025033

0.424767

0.1652305

2.9073079

25.5292050

4.1911265

5029.481355

7135.421507

51.9124061
C. "

$134.69 !$ 243.75 : 314.650 $489.5 \pi i$

62.367
106.863

353.806

172.575
457.035

140.007

534.157

294.792
34.689

8.826
8.826

122.344
18.325

18.410

$165.0 \%$

371.827
124.408 


\begin{tabular}{|c|c|c|c|c|c|}
\hline YARIABLE & M & MEAN & $\begin{array}{l}\text { STAMDARD } \\
\text { DEVIATION }\end{array}$ & $\begin{array}{l}\text { MINImUM } \\
\text { VALUE }\end{array}$ & $\underset{\substack{\text { maximUM } \\
\text { VALUE }}}{ }$ \\
\hline 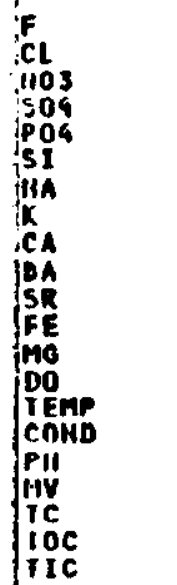 & $\begin{array}{l}37 \\
63 \\
60 \\
57 \\
21 \\
63 \\
63 \\
63 \\
63 \\
55 \\
59 \\
44 \\
62 \\
63 \\
63 \\
63 \\
63 \\
63 \\
63 \\
35 \\
55\end{array}$ & 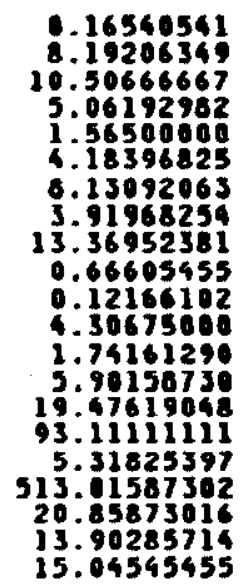 & 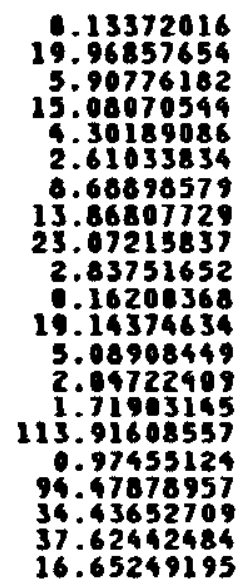 & 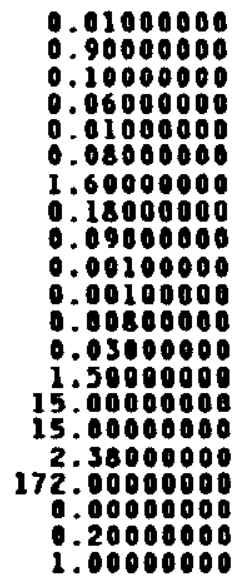 & $\begin{array}{r}0.50000000 \\
152.00000000 \\
28.000000000 \\
111.00000000 \\
15.100000000 \\
15.70000000 \\
40.10000000 \\
110.00000000 \\
105.00000000 \\
21.10000000 \\
10.61000000 \\
112.80000000 \\
39.90000000 \\
9.80000000 \\
22.00000000 \\
530.00000000 \\
7.17000000 \\
683.00000000 \\
245.00000000 \\
225.000000000 \\
71.10000000\end{array}$ \\
\hline
\end{tabular}

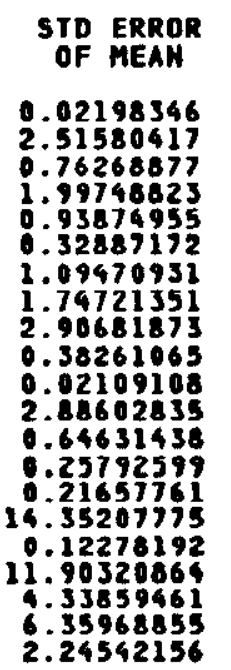

SUM

516.120000

616.100000

280.530000

32.865000

263.590000

512.248000

246.

42.28000

36.633000

7.17800

189.497000

107.980000

371.800900

3866.000000

335.050000

32320.00000

486.600000

827.300000
VARIAMCE

c.v.

0.017881

34.901650 227.42767

6.506265

75.498474

192.323568

8.051500

26245

366.483028

4.1112

12976.87455

0.949750

8926.241679

1415.597345

277.305488
80.844 243.755 297.924 274.881 106.865 333.806 172.573 426.019 133.160 292.205 34.685 122.344

18.325 165.974 270.624 


\section{Tables D3-D 20}

provide a reasonably complete summary of the statistical information Eor each variable in the groundivater systom. Calculations ivere performaj using sas (statistical inalysis systan, Sas

Institute Inc; Cary, North Carclina) proceaures on the accumulated data.

Variables reported are:

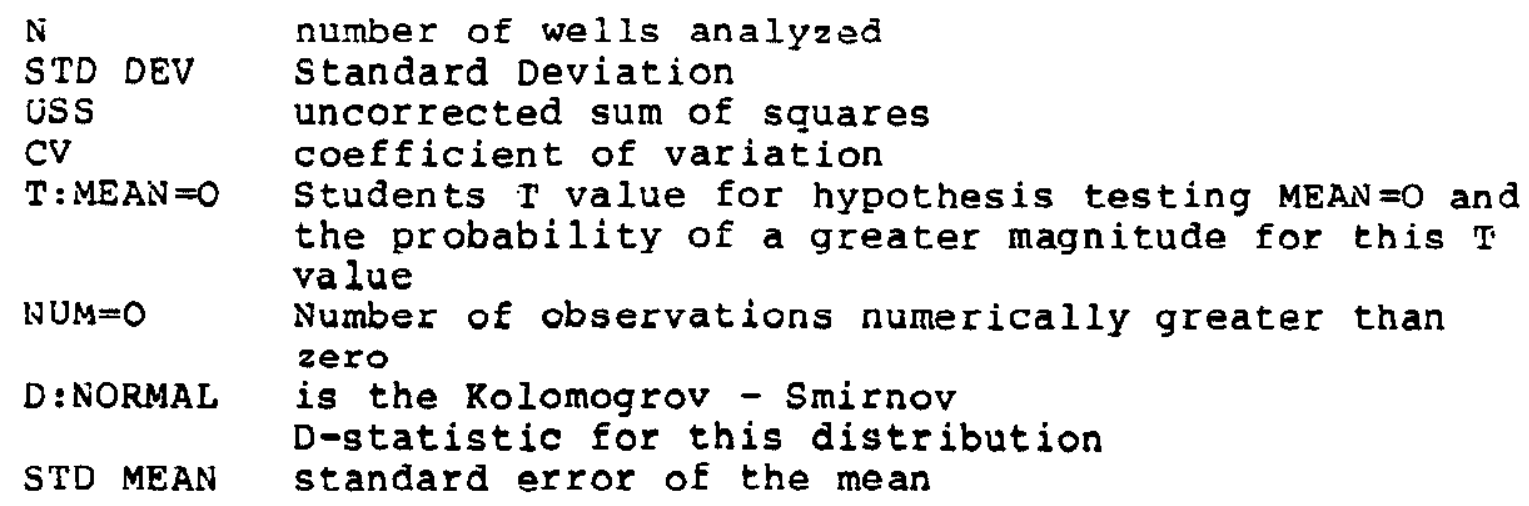

kurtosis $\quad a_{4}=\frac{m_{4}}{\left(m_{2}\right)^{2}}$

Other statistics, including guantities, extreme values, range, mode, etc., have their usual meaning.

Modified distributions, with all data points more than three standard deviations from the mean set missing, are given under the appropriate heading (GW Data with 3-sigma Values Missing). The number of values eliminated in this way is reported at the bottom of each table under the heading "Missing value Count." Variables with no "Anomalous" ( $>3$ sigma) valuas were nicrate, magnesium, dissolved oxygen (DO), and total carbon. No modified distributions were calculated for these variables. 
ALL GW DATA

UNIVARIATE

VARIABLE $=F$

MOMENTS

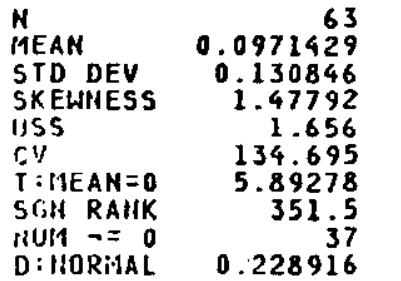

SUM WGTS

SUM WG

VARIANCE

CSS

PROB>|T 0.0002 PROB> $|S|$

0.0001

$P R O B>D$

$<0.01$

\section{TABLE $\mathrm{D}-3$}

QUANIILES (DEF $=4)$

QUANTILES (DEF=4)

$\begin{array}{crr}\text { I00X MAX } & 0.42 & 99 \% \\ 75 \% \text { Q3 } & 0.1175 & 95 \% \\ 50 \% \text { MED } & 0.04 & 90 \% \\ 25 \% \text { Q1 } & 0 & 10 \% \\ 0 \% \text { MIN } & 0 & 5 \% \\ \text { RANGE } & 0.42 & 1 \% \\ \text { Q3-QI } & 0.1175 & \\ \text { MODE } & 0 & \end{array}$

EXTREMES

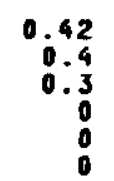

EXTREMES

\begin{tabular}{|c|c|c|c|}
\hline $\begin{array}{l}\text { LOWEST } \\
\text { OCI } \\
\text { OCI } \\
\text { OCI5 } \\
\text { OCG34 } \\
\text { OCG21 }\end{array}$ & I D & $\begin{array}{l}\text { \} } \\
\text { j } \\
\text { j }\end{array}$ & $\begin{array}{c}\text { HIGHEST ID } \\
0.4(C 15 \\
0.4(E) \\
0.4 \text { (EI) } \\
0.42(C 9) \\
0.5(A 19\end{array}$ \\
\hline
\end{tabular}

GW DATA WITH 3-SIGMA VALUES MISSIMG

UHIVARIATE

VARIABLE $=F$

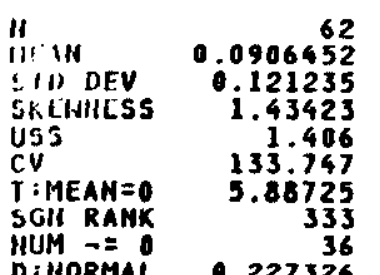

SUM WGTS

VARIAMCE

KURTOSIS

CSS MEAN

PROB > T

0.0146979

1.09275
896574

0153969

0.0001

PROB $>0$

$<0.01$

inissing value

COUNT

1.59

$\begin{array}{rr}0.5 & 99 \% \\ 0.14 & 95 \% \\ 0.05 & 90 \% \\ 0 & 10 \% \\ 0 & 5 \% \\ 0.5 & 1 \% \\ 0.14 & \\ 0 & \end{array}$

$100 \%$ MAX
$75 \%$ Q3
$50 \%$ MED
$25 \%$ Q1
$0 \%$ MIN
RANGE
Q $-Q 1$
MODE

0.5
0.4
0.318
0
0
0

0.5
0.4
318
0
0
0

\begin{tabular}{|c|c|}
\hline ; & $\begin{array}{c}\text { HIGHEST ID } \\
0.33 \text { ICJ2) } \\
0.4(C 15) \\
0.4 \text { (E) } \\
0.4(E I)\end{array}$ \\
\hline
\end{tabular}


E. L. Albenesius

$-78-$

TABLE D-4

iLt. OW DATA

IHIIVARIATE

VARIABLE $=C L$

\begin{tabular}{|c|c|c|c|}
\hline & morle & & \\
\hline 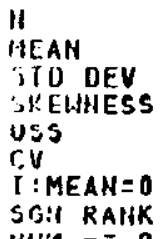 & $\begin{array}{r}63 \\
8.19206 \\
19.9686 \\
6.3848 \\
289501 \\
243.755 \\
3.25624 \\
1008\end{array}$ & $\begin{array}{l}\text { SUM WGTS } \\
\text { SUM } \\
\text { ULRIANCE } \\
\text { KURIOSIS } \\
\text { CSS } \\
\text { SID MEAN } \\
\text { PROB> } \mid \text { T } \\
\text { PROB } \mid\end{array}$ & $\begin{array}{r}53 \\
516^{63} \\
398.744 \\
44.9554 \\
247221 \\
2.5158 \\
0.00183245 \\
0.0001\end{array}$ \\
\hline D:HORMAL & 0.376613 & PROB $>D$ & $<0.01$ \\
\hline
\end{tabular}

G.J DATA WITH 3-SIGMA VALUES MISSING

UHIVARIATE

VARIABLE $=$ CL

MOMENTS

\begin{tabular}{|c|c|c|}
\hline $\begin{array}{l}\text { H } \\
\text { MEAN } \\
\text { SID DEV } \\
\text { SKEWHESS } \\
\text { USS } \\
\text { CV } \\
\text { I: MEAN =O } \\
\text { SGH RANK } \\
\text { HUHA B = O } \\
\text { D: HORHAL }\end{array}$ & $\begin{array}{r}62 \\
5.87258 \\
7.79644 \\
3.73255 \\
5846.05 \\
132.76 \\
5.93101 \\
976.5 \\
62 \\
0.288919\end{array}$ & $\begin{array}{l}\text { SUM WGTS } \\
\text { SUMA } \\
\text { VARIANCE } \\
\text { KURTOSIS } \\
\text { CSS } \\
\text { STD MEAN } \\
\text { PROB> } \mid \text { T } \\
\text { PROBD|S| } \\
\text { PROB>D }\end{array}$ \\
\hline $\begin{array}{l}\text { IISSIHG } \\
\% \text { COUH }\end{array}$ & & \\
\hline
\end{tabular}

\section{QUANTILES (DEF $=4$ )}

$\begin{array}{rc}362 & 100 \% \text { MAX } \\ 364.1 & 75 \% \text { Q3 } \\ 60.7844 & 50 \% \text { MED } \\ 14.5872 & 25 \% \text { Q1 } \\ 3707.85 & 0 \% \text { MIN } \\ 0.990148 & \text { RANGE } \\ 0.0001 & \text { QH-Q1 } \\ 0.0001 & \text { MODE } \\ <0.01 & \end{array}$

\section{QUANTILES (DEF=4)}

$100 \%$ MAX
$75 \%$ Q3
$50 \%$ MED
$25 \%$ Q1
$0 \%$ MIN
RANGE
Q3-Q1
MODE

$\begin{array}{rr}152 & 99 \% \\ 5.8 & 95 \% \\ 3.8 & 90 \% \\ 2.4 & 10 \% \\ 0.9 & 5 \% \\ 151.1 & 1 \% \\ 3.4 & \\ 2.4 & \end{array}$

DPST $-83-209$

$\begin{array}{rr}45 & 99 \% \\ 5.8 & 95 \% \\ 3.8 & 90 \% \\ 2.4 & 10 \% \\ 0.9 & 5 \% \\ 44.1 & 1 \% \\ 3.4 & \\ 2.4 & \end{array}$

EXTREMES

$$
\begin{array}{r}
152 \\
34.6 \\
10.12 \\
1.22 \\
1.22 \\
0.9
\end{array}
$$

\begin{tabular}{|c|c|c|}
\hline $\begin{array}{c}\text { LOWEST ID } \\
0.9(A) 1 \\
1 \text { (CC11 } \\
1.2(E) 3 \\
1.3(G 34 \\
1.6(A 5)\end{array}$ & $\begin{array}{l}\text { ? } \\
\text { ? } \\
\text { ? }\end{array}$ & 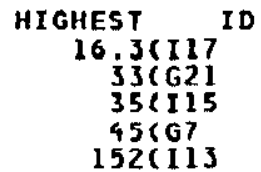 \\
\hline
\end{tabular}

EXTRENES

$$
\begin{array}{r}
45 \\
30.4948 \\
955 \\
1.7 \\
1.215 \\
0.9
\end{array}
$$

LOWEST ID
$0.9(A 11)$
$1(C) 11$
$1.2(E 13)$
$1.3(G 34)$
$1.6(A 5)$
HIGHEST
$10.4(A 19$
16.31117
$35(115$
$35(115$


E. L. ALBENESIUS

$-79-$

TABLE D-5

ALL GW DATA

UIIIVARIATE

VAR IABLE $=1103$

MOMENTS

\begin{tabular}{|c|c|c|c|c|}
\hline 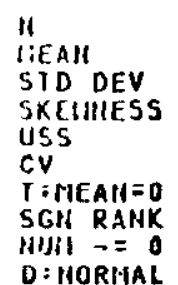 & $\begin{array}{r}63 \\
10.0063 \\
6.1887 \\
0.333874 \\
8682.6 \\
61.8477 \\
12.8335 \\
915 \\
60 \\
0.0726649\end{array}$ & $\begin{array}{l}\text { SUM WGTS } \\
\text { SUIA } \\
\text { VARIANCE } \\
\text { KURTOSIS } \\
\text { CSS } \\
\text { STD MEAN } \\
\text { PROB>|IT } \\
\text { PROB>|S| } \\
\text { PROB>D }\end{array}$ & $\begin{array}{r}63 \\
630.4 \\
38.3 \\
0.20389 \\
2374.6 \\
0.779702 \\
0.0001 \\
0.0001 \\
>0.15\end{array}$ & $\begin{array}{c}100 \% \text { MAX } \\
75 \% \text { Q3 } \\
50 \% \text { MED } \\
25 \% \text { QI } \\
0 \% \text { MIN } \\
\text { RANGE } \\
\text { Q3-Q1 } \\
\text { MODE }\end{array}$ \\
\hline
\end{tabular}

QUANTILES (DEF=4)

$\begin{array}{rr}28 & 99 \% \\ 14.1 & 95 \% \\ 10.5 & 90 \% \\ 5.4 & 10 \% \\ 0 & 5 \% \\ 28 & 1 \% \\ 8.7 & \\ 0 & \end{array}$

$P R O B>D$

$>0.15$

D N MORIIAL

0.0726649

DPST-83-209

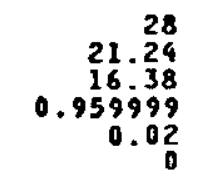
LOWEST

OCI7
O(C19
orC9
$0.1(G 7)$
$0.5(G 23$

HIGHEST ID

16.82615
18.26034

22 (I)

25 . 2 (E) 
TABLE D-6

iL GW DATA IJHIVARIATE

VAR IABLE $=504$

MOMENTS

IN

MEAN

STD DEV

SXEWIIES

USS

$I: M E A N=0$

SGN RANK

$D=$ NORMAL

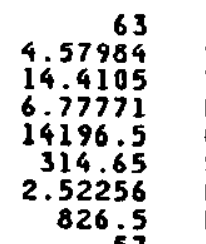

0.382069

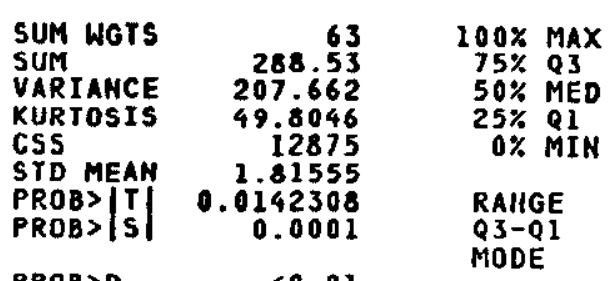

$P R O B>D$

$<0.01$

GW DATA WITH 3-5IGMA VALUES MISSING

UHIVARIATE

$\checkmark A R I A B L E=504$

MOMENTS

QUANTILES (DEF $=4)$

$\begin{array}{rr}24 & 99 \% \\ 3.35 & 95 \% \\ 1.3 & 90 \% \\ 0.3 & 10 \% \\ 0 & 5 \% \\ 24 & 1 \% \\ 3.05 & \\ 0 & \end{array}$

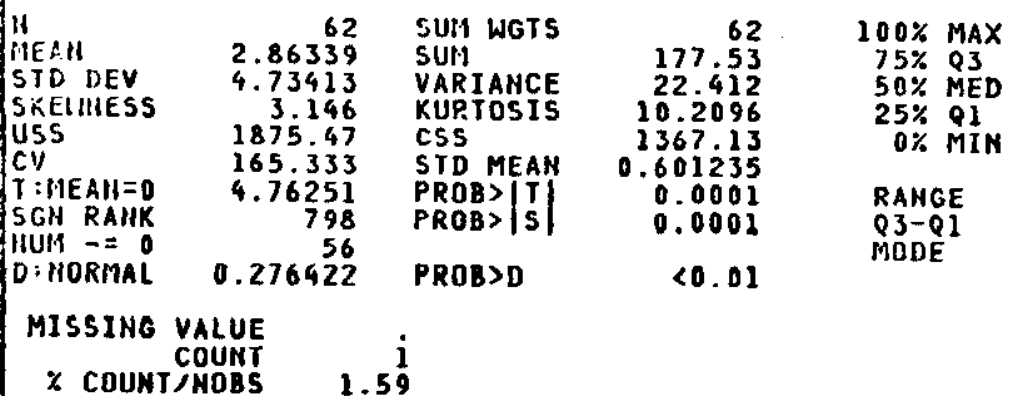

1.:11. 11:

\begin{tabular}{|c|c|c|c|}
\hline $\begin{array}{l}\text { LOLISS I ID } \\
\text { OCI155 } \\
\text { OCE36 } \\
\text { OCE ES } \\
\text { OCE32 } \\
\text { OCE9 }\end{array}$ & $\begin{array}{l}\{ \\
\} \\
\} \\
\}\end{array}$ & $\begin{array}{r}11 \text { IHI } 51 \\
7.2(19 \\
15.8115 \\
16.4103 \\
21(69) \\
24(C 5\end{array}$ & I D \\
\hline
\end{tabular}

MISSING VALUE

* COUNT COUNT

1.59

\section{QUANTILES (DEF $=4$ )}

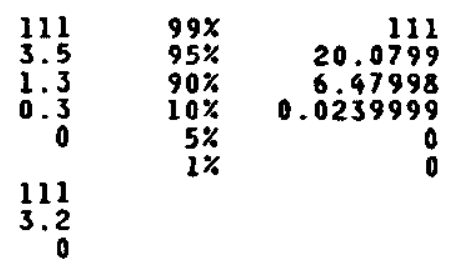

LOWES

O(I15)
O(E36 )
O(E34
OCE32 )
O(E9

HIGHEST

$15.8(A 5$

$16.4 \mathrm{CC}$

$216 \mathrm{Gg}$

$24(\mathrm{CS})$
111 (E1)

24
16.31
5.34
0.0179998
0
0

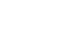


E. L. ALBENES IUS

$-81-$

TABLE D-7

ALL GW DATA

UNIVARIATE

VARIABLE=PO4

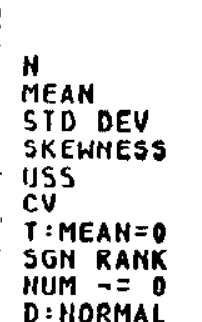

MOME
63
0.521667
2.55398
5.38197
421.559
489.581
1.62123
115.5
0.490821

MOMENTS

MEAN

SID DEV

SKEW

D : HORMAL

0.490821

$\begin{array}{rc}32.865 & 100 \% \text { MAX } \\ 6.52281 & 55 \% \text { Q3 } \\ 28.3111 & 25 \% \text { MED } \\ 404.414 & 0 \% \text { MIN } \\ 0.321771 & \text { RANGE } \\ 0.110043 & \text { RAJ } \\ 0.0001 & \text { MODE } \\ <0.01 & \end{array}$

QUANTILES(DEF $=4)$

$\begin{array}{rr}15.1 & 99 \% \\ 0.02 & 95 \% \\ 0 & 90 \% \\ 0 & 10 \% \\ 0 & 5 \% \\ 15.1 & 1 \% \\ 0.02 & \\ 0 & \end{array}$

QUANTILES (DEF=4)

$100 \%$ MAX
$75 \%$ Q3
$50 \%$ MED
$25 \%$ Q1
$0 X$ MIN
RANGE
Q3-Q1
MODE

$\begin{array}{rr}1.8 & 99 \% \\ 0.015 & 95 \% \\ 0 & 90 \% \\ 0 & 10 \% \\ 0 & 5 \% \\ 1.8 & 1 \% \\ 0.015 & \\ 0 & \end{array}$

DPST-83-209

GW DATA WITH 3-5IGMA VALUES MISSING

UNIVARIATE

VARIABLE $=P 04$

MOMENTS

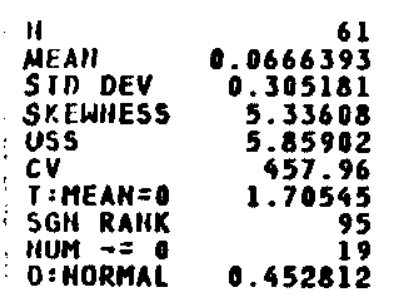

SUM WGTS

SUM

VARIANCE 0.093 i356

KURYOSIS 27.755

CSS 5.58814

C.0390745

PROB>|II 0.09328

PROS>D

$<0.01$

MISSIMG VALUE

$\times$ COUNT/NOBS

3.17
EXIREMES

\begin{tabular}{|c|c|c|}
\hline 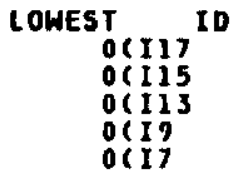 & $\begin{array}{l}\} \\
\xi \\
\xi\end{array}$ & $\begin{array}{c}\text { HIGHEST ID } \\
0.07 \text { (AS } \\
0.07(C 5) \\
0.2 \text { (I) } \\
1.6(C 23) \\
1.8(A) 6\end{array}$ \\
\hline
\end{tabular}


ALL GW DATA

UHIVARIATE

VARIABLE $=S I$

MOMENTS

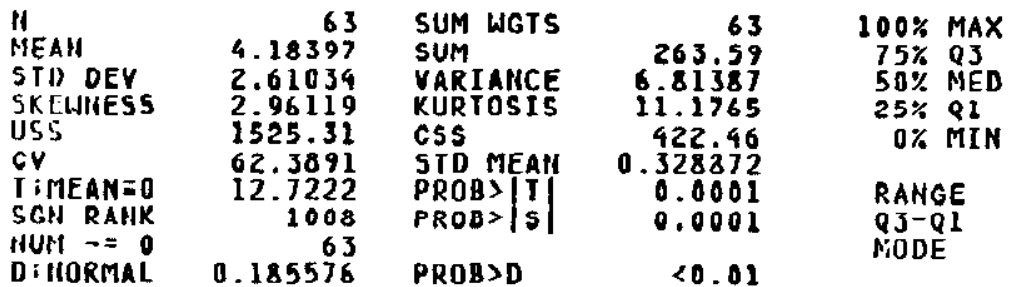

广ABLE D-8

QUANTILES (DEF $=4$ )

$\begin{array}{rr}15.7 & 99 \% \\ 4.72 & 95 \% \\ 3.6 & 90 \% \\ 2.9 & 10 \% \\ 0.08 & 5 \% \\ 15.62 & 1 \% \\ 1.82 & \\ 3 & \end{array}$

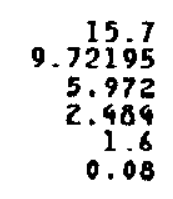

15.7
72195
5.972
2.484
1.6
0.08
EXTREMES

\begin{tabular}{|c|c|c|}
\hline $\begin{array}{l}\text { LOWEST ID } \\
0.08(C 9 \\
1.04(115 \\
1.59(C 19 \\
1.64(62) \\
2.16(C) 7\end{array}$ & \} & $\begin{array}{l}\text { HICHEST ID } \\
6.38(\mathrm{COS} \\
6.61(\mathrm{ES} \\
10.5(\mathrm{CS} \\
15.7(\mathrm{AS} \\
15.7(\mathrm{CS})\end{array}$ \\
\hline
\end{tabular}

CIN DATA HITH 3-SIGMA VALUES mISSIHG

UHIVARIATE

VARIABLE $=S I$

MOMENTS

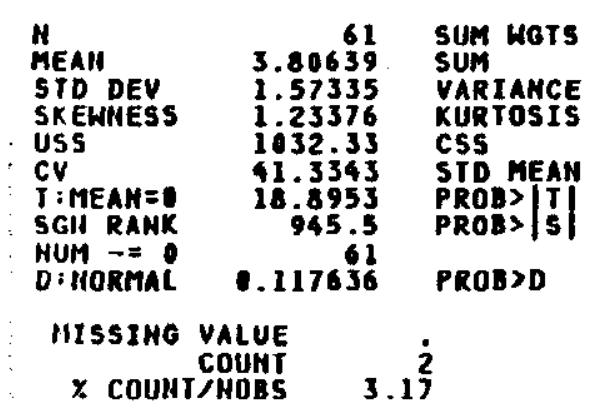

$\begin{array}{rc}232.19 & 100 \% \text { MAX } \\ 2.47542 & 75 \% Q 3 \\ 4.52265 & 25 \% \text { MED } \\ 148.525 & 0 \% \text { MIN } \\ 0.201447 & \text { RANGE } \\ 0.0001 & Q 3-Q 1 \\ 0.0001 & \text { MODE } \\ 0.035 & \end{array}$

QUANTILES (DEF=4)

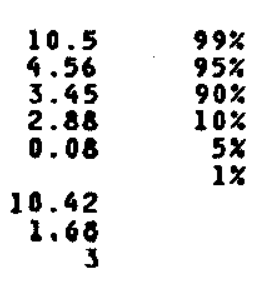

EXTREMES

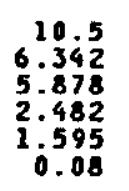

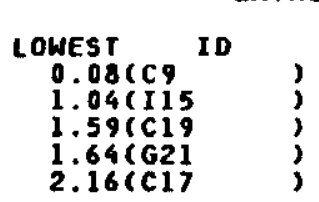
HIGHEST ID
6CEI
$6.38\left(\mathrm{GLS}^{2}\right.$
$6.61(\mathrm{ES}$
$10.5 \mathrm{CS}$


ALL GW DATA UNIVARIATE

VARIABLE $=N A$

MOMENTS

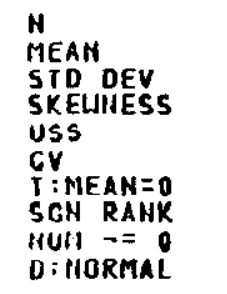

$\begin{aligned} 63 & \text { SUM WGTS } \\ 8.13092 & \text { SUM } \\ 8.68899 & \text { VARIANCE } \\ 2.54631 & \text { KURTOSIS } \\ 8845.95 & \text { CSS } \\ 106.063 & \text { SID MEAN } \\ 7.42747 & \text { PROBS|Y } \\ 1008 & \text { PROBS|S| } \\ 0.316913 & \text { PROB>D }\end{aligned}$

TABLE D-9

\section{GW DATA HITH 3-SIGMA VALUES MISSIHG}

\section{UNIVARIATE}

VARIABLE=NA

MOMENTS

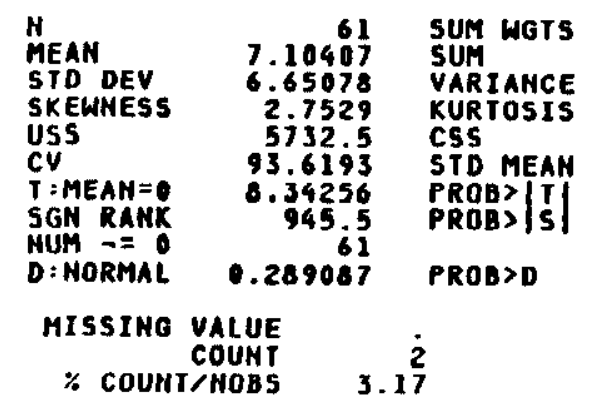

QUANTILES (DEF=4)

$\begin{array}{rc}433.348 & 100 \% \text { MAX } \\ 44.2328 & 75 \% \text { Q3 } \\ 7.50707 & 25 \% \text { MED } \\ 2653.97 & 0 \% \text { MIN } \\ 0.851545 & \text { RANGE } \\ 0.0001 & \text { RAKG } \\ 0.0001 & \text { Q3-Q1 } \\ & \text { MODE }\end{array}$

$\begin{array}{rr}32.3 & 99 x \\ 6.71 & 95 \% \\ 5.32 & 90 \% \\ 4.005 & 10 \% \\ 1.6 & 5 \% \\ 30.7 & 1 x \\ 2.705 & \\ 2.9 & \end{array}$

QUANTILES (DEF $=4$ )

$\begin{array}{lrr}100 \% \text { MAX } & 40.1 & 99 \% \\ 75 \% \text { Q } & 7.3 & 95 \% \\ 50 \% \text { MED } & 5.55 & 90 \% \\ 25 \% \text { QI } & 4.01 & 10 \% \\ 0 \% \text { MIN } & 1.6 & 5 \% \\ \text { RANGE } & 38.5 & 1 \% \\ \text { PJ-Q1 } & 3.29 & \\ \text { MODE } & 2.9 & \end{array}$

Exrinlits

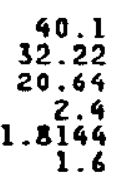

32.22
20.64

2.4
1.8144
1.6
HICHEST IO $30(6: 1)$
$31.7(\mathrm{C})$ $31.7(\mathrm{C})$ $33.8(\mathrm{Cg}$ 40.26113
EXTREMES

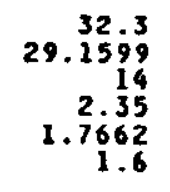




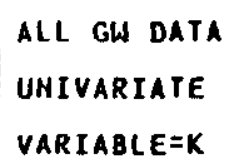

136.92 136.94
8.02503 18.0518 489527

.359772

0.0001

0.0001

$<0.01$
QUANTILES(DEF $=4$ )

$\begin{array}{lrr}200 \% \text { MAX } & 110 & 99 \% \\ 75 \% \text { QS } & 2.8 & 95 \% \\ 50 \% \text { MED } & 1.27 & 90 \% \\ 25 \% \text { Q1 } & 0.89 & 10 \% \\ 0 \% \text { MIN } & 0.18 & 5 \% \\ \text { RANGE } & 209.82 & 1 \% \\ \text { Q3-01 } & 1.91 & \\ \text { MODE } & 0.77 & \end{array}$

EXTREMES

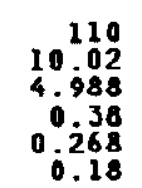

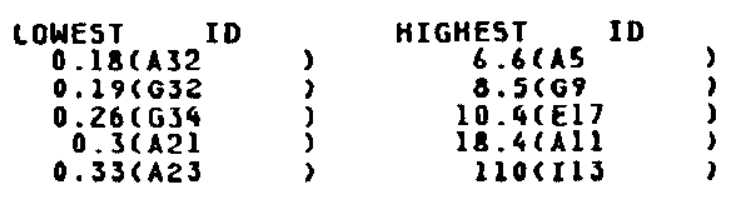

QUANTILES(DEF $=4$ )

$\begin{array}{lrr}100 \% \text { MAX } & 18.4 & 99 \% \\ 75 \% \text { Q3 } & 2.6875 & 95 \% \\ 50 \% \text { MED } & 1.25 & 90 \% \\ 25 \% \text { Q1 } & 0.88 & 10 \% \\ 0 \% \text { MIN } & 0.18 & 5 \% \\ \text { RAIIGE } & 18.22 & 1 \% \\ \text { Q3-O1 } & 1.8075 & \\ \text { MODE } & 0.77 & \end{array}$

EXTREMES

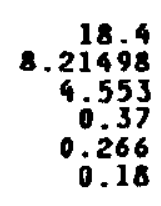
HIGHEST ID
5.18 (C)
6.6 CAS
8.5 (G9
10.4 (E1)
18.4 CA11 
TABLE D-11

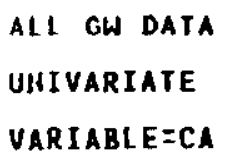

$\begin{array}{rc}842 & 100 \% \text { MAX } \\ 842.28 & 75 \% \text { Q3 } \\ 532.324 & 50 \% \text { MED } \\ 8.02215 & 25 \% \text { Q1 } \\ 33004.1 & 0 \% \text { MIN } \\ 2.98682 & \text { RAHGE } \\ 0.0001 & \text { RH Q Q } \\ 0.0001 & \text { MODE } \\ <0.01 & \end{array}$

104.91

16 is
QUANTILES ( DEF $=4$ )

$\begin{array}{rrr}105 & 99 \% & 85.0395 \\ 17.2 & 95 \% & 85.030 \\ 3.3 & 90 \% & 0.94 \\ 1.05 & 10 \% & 0.344 \\ 0.09 & 5 \% & 0.184 \\ 104 & 1 \% & 0.09\end{array}$

\section{QUANTILES ( DEF $=4$ )}

$\begin{aligned} 60 & \text { SUM WGTS } \\ 9.04467 & \text { SUM } \\ 12.5867 & \text { VARIANCE } \\ 2.00528 & \text { KURTOSIS } \\ 14255.4 & \text { CSS } \\ 139.161 & \text { SID MEAN } \\ 5.56617 & \text { PROB> TI } \\ 915 & \text { PROB> S } \\ 60 & \text { PROB>D } \\ 0.241907 & \text { PROB>D } \\ \text { LUE } & \\ \text { UHT } & 3\end{aligned}$

$60 \quad 100 \% \max$ $542.68 \quad 75 \%$ Q3 158.425 3.72424 1.62493 0.0001 0.0001 $<0.01$ $25 \%$ QI 0\% MIM RANGE MODE

$\begin{array}{rr}56 & 99 x \\ 10.05 & 95 \% \\ 3.2 & 90 \% \\ 0.93 & 10 \% \\ 0.09 & 5 \% \\ & 1 \%\end{array}$

EXTREMES

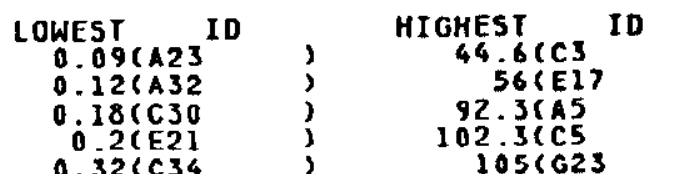

$105(023$

MISSIHG VAlUE

COUHT

$4.76^{3}$ 
TA:L: J-12

ALL GW DATA UNIVARIATE

VARIABLE $=B A$

N
MEAK
STD DEV
SKEWHESS
USS
CV
T:MEAH=O
SGII RANK
IIUII T= O O
D: MORMAL

MOMENTS

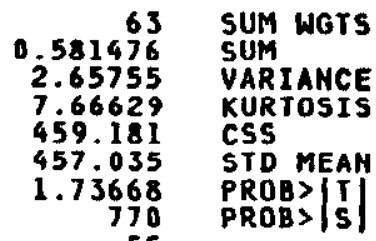

0.413402 PROB $>D$
QUANTILES(DEF $=4)$

$\begin{array}{crr}100 \% \text { MAX } & 21.1 & 99 \% \\ 75 \% \text { Q } & 0.38 & 95 \% \\ 50 \% \text { MED } & 0.05 & 90 \% \\ 25 \% \text { Q1 } & 0.01 & 10 \% \\ 0 \% \text { MIN } & 0 & 5 \% \\ \text { RAHGE } & 21.1 & 1 \% \\ \text { Q3-Q1 } & 0.37 & \\ \text { MODE } & 0.01 & \end{array}$

EXTREMES

QUAHTILES (DEF=4)

$100 \%$ MAX
$75 \%$ Q3
$50 \%$ MED
$25 \%$ QI
$0 \%$ MIN
RAMGE
Q3-QI
MODE

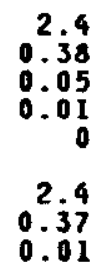

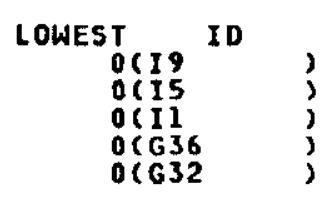

HIGHEST ID
0.83 (E)
0.92 (G)
1.2 CC 36
2.4 (I1)
21.1 (113

GW DATA WITH 3-5IGMA VALUES MISSING

T!HIVARIATE

VARIABLE=BA

MOMENTS

NEAN
MEAD DEV
SID DEV
SYEWIIISS
USS
CU
T:MEAN $=0$
SCN RANK
MUH $\rightarrow=0$

62 SUM HGTS

0.406486 VARIAHCE

2.95361 KURIOSIS

1329706

4.85305

PROB> T

$\begin{aligned} & \text { PROB S } \\ & \text { PROBS }\end{aligned} \mid$

D) : HORMAL

0.268836

PROB > D

1502
15.533
0.16523
12.1071
10.0791
0.0516237
0.0001
0.0001
$<0.01$

missing VAlUe

COUNIT

1.59 
TADL: ; -13

ALL GW DATA

UHIVARIATE

VARIABLE $=S R$

MOMENTS

MEAN

STD DEV

SKEWHESS

USS

T:MEAN $=0$

SGH RANK

D:IIORMAI

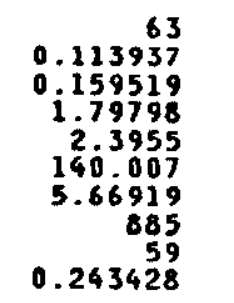

SUM WGTS
SUM
VARIANCE
KURTOSIS
CSS
STD MEAK
PROB>
PROB
PROB
PROB $>$ D

7.178
0.0254463
2.39201
1.57767
0.0200975
0.0001
0.0001
$<0.01$

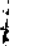

GU DATA HITH 3-SIGMA VALUES MISSIMG

UHIVARIATE

VARIABLE $=S R$

MOMENTS

\begin{tabular}{|c|c|c|c|}
\hline 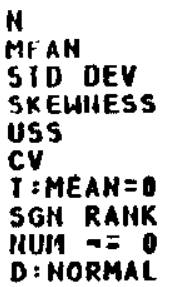 & $\begin{array}{r}61 \\
0.0978361 \\
0.134134 \\
i .81087 \\
1.6634 \\
137.101 \\
5.69672 \\
826.5 \\
57 \\
0.237937\end{array}$ & $\begin{array}{l}\text { SUM WGTS } \\
\text { SUM } \\
\text { VARIANCE } \\
\text { KUR YOSIS } \\
\text { CSS } \\
\text { STD MEAM } \\
\text { PROB>| T } \\
\text { PROB> SOS } \\
\text { PROB >D }\end{array}$ & $\begin{array}{r}61 \\
5.968 \\
0.017992 \\
2.54949 \\
1.07952 \\
0.0171741 \\
0.0001 \\
0.0001\end{array}$ \\
\hline & & & \\
\hline
\end{tabular}

3.17
QUANTILES (DEF=4)

$\begin{array}{lrl}\text { 100X MAX } & 0.51 & 99 \% \\ 75 \% \text { Q3 } & 0.135 & 95 \% \\ 50 X \text { MED } & 0.03 & 90 \% \\ 25 X \text { QI } & 0.01 & 10 \% \\ \text { OX MIN } & 0 & 5 \% \\ \text { RANGE } & 0.51 & 1 \% \\ \text { Q3-Q1 } & 0.125 & \\ \text { MODE } & 0.01 & \end{array}$

$\begin{array}{crr}100 \% \text { MAX } & 0.61 & 99 \% \\ 75 \% \text { Q3 } & 0.14 & 95 \% \\ 50 \% \text { MED } & 0.04 & 90 \% \\ 25 \% \text { Q1 } & 0.01 & 10 \% \\ 0 \% \text { MIN } & 0 & 5 \% \\ \text { RAIIGE } & 0.61 & 1 \% \\ \text { Q3-Q1 } & 0.13 & \\ \text { MODE } & 0.01 & \end{array}$

EXTREMES

\begin{tabular}{|c|c|c|}
\hline $\begin{array}{c}\text { LOWEST ID } \\
\text { OCGS2 } \\
\text { OCGI3 } \\
\text { OCEL1 } \\
0 \text { CCIS } \\
0.001 \text { (A23 }\end{array}$ & $\begin{array}{l}\xi \\
\xi \\
\xi \\
\xi\end{array}$ & $\begin{array}{c}\text { HIGHEST ID } \\
0.48(113) \\
0.5(C 36 \\
0.51(C 23 \\
0.6(A 5) \\
0.61(C 5)\end{array}$ \\
\hline
\end{tabular}

$0.001(A 23$

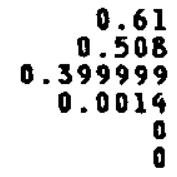


aLL GW Data

UHIVARIATE

VARIABLE=FE

MOMENTS

MEAH

SID DEV

SKEWHESS

USS

$T$ : MEAII $=0$

SCH RAHK

D: HORAAL

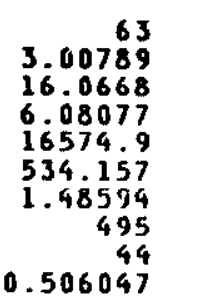

SUM WGTS
SUM
VARIANCE
KURTOSIS
CSS
STD MEAM
PROB $|T|$
PROB $\mid$ S
PROB $>D$

\subsection{7}

258.144

38.5313

16004.9

$0^{2} .02423$

.142362

$<0.01$
ZNELL J-14

QUANTILES (DEF=4)

$100 \%$ MAX
$75 \%$ Q3
$50 \%$ MED
$25 \%$ Q1
$0 \%$ MIN
RANGE
Q3-Q1
MODE

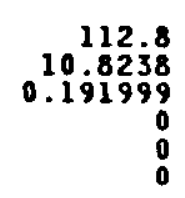

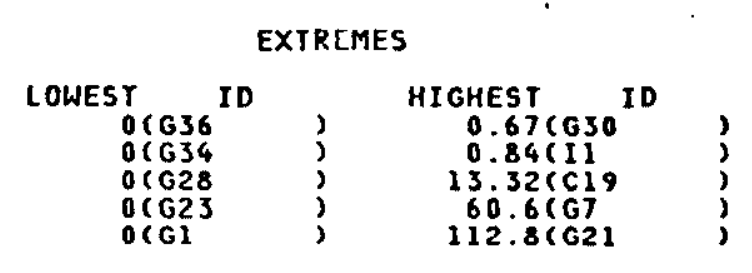

GH DaTa WITH 3-SIgMa VALUES MISSING

UHIVARIATE

VARIABLE=FE

MOHENIS

QUANTILES (DEF=4)

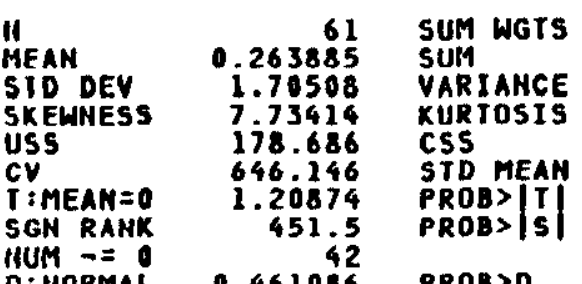

$\begin{array}{cc}16.091 & 100 X \text { MAX } \\ 75 \% \text { Q } \\ 2.90731 & 50 \% \text { MED } \\ 60.1681 & 25 \% \text { Q1 } \\ 174.438 & \text { OX MIN } \\ 0.218314 & \text { RANGE } \\ 0.231503 & \text { RANGE } \\ 0.0001 & \text { Q3-Q1 } \\ & \text { MODE }\end{array}$

$$
\begin{array}{r}
13.32 \\
0.025 \\
0.012 \\
0 \\
0 \\
13.32 \\
0.025
\end{array}
$$

\begin{tabular}{|c|c|c|}
\hline $\begin{array}{l}\text { LOHEST ID } \\
\text { O(G36 } \\
\text { O(G34 } \\
\text { O(G28 } \\
\text { OCG23 } \\
\text { O (GI }\end{array}$ & $\begin{array}{l}\text { \{ } \\
\xi \\
\xi\end{array}$ & $\begin{array}{c}\text { HIGHEST ID } \\
0.15(\mathrm{Cg} \\
0.22(\mathrm{Gg} \\
0.67(\mathrm{G} 30 \\
0.84(\mathrm{II}) \\
13.32(\mathrm{Cl})\end{array}$ \\
\hline
\end{tabular}

EXTREMES
MISSING VALUE

\% COUNTINOAS

3.17 
MOMELTS

MEAII

MEAH" DEV

STD DEV
SRELHESS

USS

I: MEAN $=0$

SCHi RAHK

Di HORIMAL
SUM WGTS

SUM IANCE

VARIANCE
KURTOSIS

CSS

PROB>IT

$P R O B>|T|$
$P R O B>|S|$

$P R O B>D$

$\begin{array}{rc}107 & 63 \\ 107.98 & 100 \% \text { MAX } \\ 25.5292 & 55 \% \text { Q3 } \\ 54.8558 & 25 \% \text { MED } \\ 1582.81 & 0 \% \text { MIN } \\ 0.636573 & \text { RANGE } \\ .00910809 & \text { RANG } \\ 0.0001 & \text { Q3-Q1 } \\ <0.01 & \text { MODE }\end{array}$

\section{QUANTILES (DEF $=4$ )}

$\begin{array}{rr}39.9 & 99 \% \\ 1.5 & 95 \% \\ 0.66 & 90 \% \\ 0.35 & 10 \% \\ 0 & 5 \% \\ 39.9 & 1 \% \\ 1.15 & \\ 0.34 & \end{array}$

EXIREMES

$$
\begin{array}{r}
39.9 \\
4.14599 \\
3.05 \\
0.174 \\
0.14
\end{array}
$$

\begin{tabular}{|c|c|c|}
\hline \multicolumn{3}{|c|}{ EXIREMES } \\
\hline $\begin{array}{l}\text { LOWEST } \\
0(C 19 \\
0.03(A) 1 \\
0.14(C 21) \\
0.14(\mathrm{G} 28 \\
0.15(\mathrm{~A})\end{array}$ & $\begin{array}{l}\{ \\
\} \\
\}\end{array}$ & $\begin{array}{c}\text { HIGHEST ID } \\
3.4 \text { IA5 } \\
3.53 \text { IG } \\
4.3(\mathrm{GL} 1 \\
7.6(115 \\
39.9 \text { (G) }\end{array}$ \\
\hline
\end{tabular}


E. L. ALBENES IUS

ALL GIN DATA

UIIIVARIATE

VARIABLE $=$ DO

MOMENTS

"II

STD DEV

SKEWHESS -0.417779

CV

34.6894 STD MEAN

SGII RAKIK

MUM $=0$

22.8809

D:NORIAAL 0.0779735

SUM WGTS

VARIAHCE

CSS

$\begin{aligned} & \text { PROB }> \\ & \text { PROB > }\end{aligned} \mid$

$P R O B>D$
$-90-$

DPST $-83-209$
TABLE D-16

QUANTILES (DEF =4)

$\begin{array}{rr}9 & 99 \% \\ 7.5 & 95 \% \\ 4.5 & 90 \% \\ 1.5 & 10 \% \\ 7.5 & 5 \% \\ 3 & \\ 8.6 & \end{array}$

EXTREMES

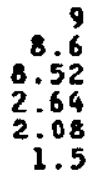

MIGHEST $8.6(A 32$

$8.6(\mathrm{Cl} 17$

$8.6(034$

$8.7<034$

9रI 1$)$ 
E. L. ALBENESIUS

$-91-$

'AALLE D-17

ALL GW DATA

UNIVARIATE

VARIABLE = TEIAP

MOMENTS
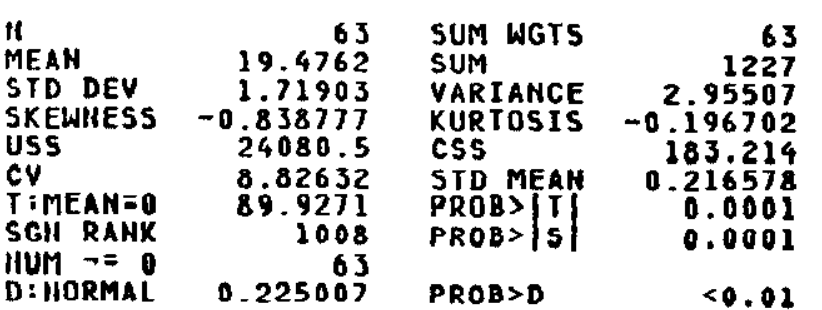

$100 \%$ MAX

$75 \%$ Q3 50\% MED $0 \%$ MIN

QUANTILES (DEF $=4$ )

\begin{tabular}{ccr} 
& \multicolumn{3}{c}{ QUANTILES(DEF $=4)$} \\
MAX & 22 & $99 \%$ \\
ED & 21 & $95 \%$ \\
IN & 18 & $90 \%$ \\
& 15 & $5 \%$ \\
& 7 & $1 \%$ \\
& 3 & \\
& 21 &
\end{tabular}

\section{RANGE}

RODQ
DPST-83-209

EXTREMES

22
21
21
17
16.2
15


TABLE D-18

ALL GN DATA

UHIVARIATE

VARIABLE = COND

MOMEUTS

MEAN

STD DEV

SKEWHES

USS

T:MEAN $=0$

SGH RANK

IUMTOZO=O

93.113
931311
113.916
2.56577
1350756
122.394
6.48764
1008
0.262935

SUM WGTS

SUM

VARIANCE

KURTOSIS

SSS MEAN

PROB> $\mid$\begin{tabular}{|c|}
$T$ \\
$S$
\end{tabular}

PROB> 5

$P R O B>D$

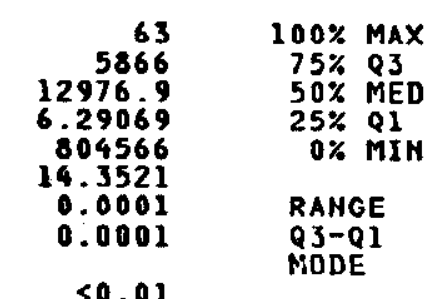

QUANTILES(DEF =4)

$\begin{array}{rr}530 & 99 \% \\ 100 & 95 \% \\ 47 & 90 \% \\ 31 & 10 \% \\ 15 & 5 \% \\ 515 & 1 \% \\ 69 & \\ 30 & \end{array}$

431530

262
25
20

$<0.02$

FV DATA WITH 3-SIGMA VALUES MISSIHO

IINIVARTATE

"ARIABLE = COHD

MOMENTS

MEAN

STD DEV

SKEWMESS

iss

CV

SOH RANK

IUM $=$

1): HORMAL

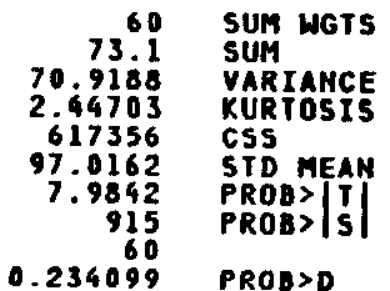

438

4386

6.24624

296739

9.15558

0.0001

0.0001

$<0.01$

missing value

* COUNT/NOBS

3
4.76
PUANTILES ( DEF $=4$ )

100\% $\operatorname{maX}$

$75 \%$ Q3

$25 \%$ Q1

$0 \%$ MIN

RANGE

Q3-Q1

MODE

$\begin{array}{rr}360 & 99 \% \\ 88.75 & 95 \% \\ 45.5 & 90 \% \\ 30.25 & 10 \% \\ 15 & 5 \% \\ 345 & 1 \% \\ 58.5 & \\ 30 & \end{array}$

360
269
139.8
25
20
15

EXTREMES

LOWEST ID
15 (C2)
20 (E)
20 (C15
20 (C11
20 CA21

HIGHEST 310 (E1) 360 CAS 450 (II) $500(\mathrm{G})$ $530<\mathrm{G}$

EXIREMES

\begin{tabular}{|c|c|c|}
\hline $\begin{array}{l}\text { LOWEST ID } \\
15(C 21 \\
20(\text { E } 13 \\
20(C 15 \\
20(C 11) \\
20(A 2)\end{array}$ & \{ & $\begin{array}{c}\text { HIGHEST ID } \\
170 \text { CCS } \\
250 \text { CC9 } \\
270 \text { C } 23 \\
310 \text { CE17 } \\
360 \text { CAS }\end{array}$ \\
\hline
\end{tabular}


$\therefore L L$ GW DATA

\section{INIVARIATE}

VARIABLE $=P H$

MOMENT.S

$\begin{array}{lr}\text { N } & 63 \\ \text { MEAN } & 5.31825 \\ \text { STD DEV } & 0.974551 \\ \text { SYEWHESS } & -0.504402 \\ \text { USS } & 1840.77 \\ \text { CV } & 18.3246 \\ \text { T:ITEAH=0 } & 43.3146 \\ \text { SGH RAIIK } & 1008 \\ \text { NUII EZ O } & 63 \\ \text { D: IIORHAL } & 0.0567663\end{array}$

SUM WGTS SUM VARIANCE CSS MEAM STD MEA $\begin{aligned} & \text { PROB }> \\ & \text { PROB> }\end{aligned} \mid$ $P R O B>D$
TAELP D-19

QUANTILES (DEF=4)

$\begin{array}{rc}335.03 & 100 \% \text { MAX } \\ 0.94975 & 55 \% \text { Q3 } \\ 0.467874 & 25 \% \text { MED } \\ 58.8845 & 0 \% \text { MIN } \\ 0.122782 & \text { RANGE } \\ 0.0001 & \text { Q3-Q1 } \\ 0.0001 & \text { MODE }\end{array}$

$\begin{array}{ll}7.17 & 99 \% \\ 6.04 & 95 \% \\ 5.39 & 90 \% \\ 4.67 & 10 \% \\ 2.38 & 5 \% \\ 4.79 & 1 \% \\ 1.37 & \\ 5.4 & \end{array}$

QUANTILES(DEF $=4)$

100\% MAX
$75 \%$ Q
$50 \%$ MED
$25 \%$ QI
O\% MIN
RAMGE
Q3-Q1
MODE

7.17
6.85
6.576
4.162
3.536
2.38

$\begin{array}{rr}7.17 & 99 \% \\ 6.0575 & 95 \% \\ 5.395 & 90 \% \\ 4.685 & 10 \% \\ 2.91 & 5 \% \\ 4.26 & 1 \% \\ 1.3725 & \\ 5.4 & \end{array}$

\begin{tabular}{|c|c|c|c|c|}
\hline \multicolumn{4}{|c|}{ EXTREMES } & \\
\hline $\begin{array}{l}\text { LOWEST } \\
2.38 \text { (E) } \\
2.91 \text { (E13 } \\
3.45(\mathrm{G} 36 \\
3.88 \text { (E) } \\
4.07 \text { (E30 }\end{array}$ & ID & $\begin{array}{l}\text { } \\
\} \\
\xi \\
\xi\end{array}$ & $\begin{array}{l}\text { HIGHEST } \\
6.64(C 9 \\
6.81(\mathrm{AS} \\
6.86(\mathrm{C5} \\
6.95(A 3) \\
7.17(\mathrm{CE})\end{array}$ & ID \\
\hline
\end{tabular}

GW DATA WITH 3-SIGMA VALUES MISSIHG UHIVARIATE

\section{VARIABLE $=P H$}

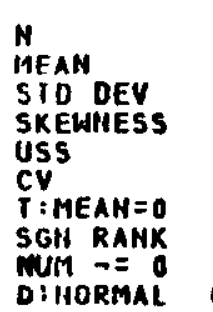$$
\text { MOMENTS }
$$

MISSING VALUE

COUHY
\% counT/NOBS

1.59
SUM WGTS SUM

VARIANCE$$
\text { CSS }
$$

CSS

STD MEAN $\begin{aligned} & \text { PROB } \\ & \text { PROB }>\mid\end{aligned} \mid$

PROB>D

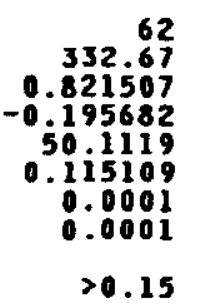

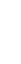


AIL GW DATA

UHIVARIATE

VARIABLE=MV

\section{MOMENTS}

H

MIEAN

STD DEV

IISS

USS

$T: M E A H=0$

SGII RAIIK

$D$ : HORIIAL

513.033 513.016 94.4788 17134100 8.4163 43.099 1008 0.135181

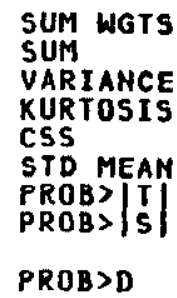

63
32320
8926.24
2.00051
553427
11.9032
0.0001
0.0001
$<0.01$

QUANTILES(DEF $=4$ )

$100 \%$ MAX
$75 \%$ Q3
$50 \%$ MED
$25 \%$ Q1
$0 \%$ MIN
RANGE
Q3-Q1
MODE

$\begin{array}{ll}683 & 99 \% \\ 567 & 95 \% \\ 536 & 90 \% \\ 452 & 10 \% \\ 172 & 5 \% \\ 511 & 1 \% \\ 115 & \\ 541 & \end{array}$

TABLE $0 \cdot 20$
EXTREMES

683
660.2
630
392.8
349.8
172

HIGHEST 642117 662 (II 668 (6) 688 (CIJ

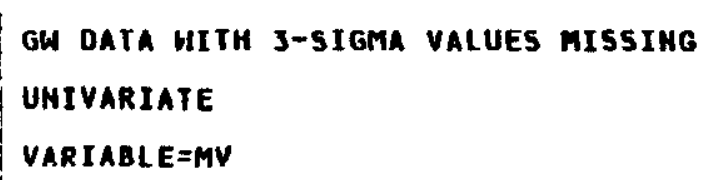

QUANTILES (DEF=4)

$\begin{array}{rc}62 & 100 \% \text { MAX } \\ 32148 & 75 \% 93 \\ 7135.4 & 50 \% \text { MED } \\ 0.351507 & 25 \% 91 \\ 435259 & 0 \% \text { MIN } \\ 10.7279 & \text { RANGE } \\ 0.0001 & \text { RI-QQ } \\ 0.0001 & \text { MODE } \\ 0.012 & \end{array}$

683
568
537
455
264
419
113
541

$\begin{array}{rr}99 \% & 683 \\ 95 \% & 660.65 \\ 90 \% & 631 \\ 10 \% & 396.4 \\ 5 \% & 370.5 \\ 1 \% & 264\end{array}$

EXTREMES

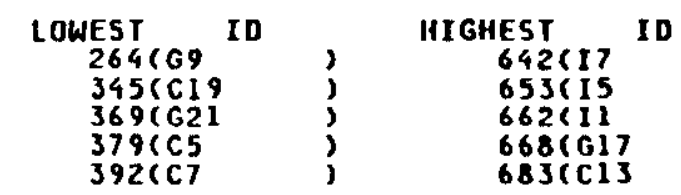


E. L. ALbENESiUS

$-95-$

TABLED-II

ALL GW DATA

UHIVARIATE

VARIABLE $=T C$

MOMENTS

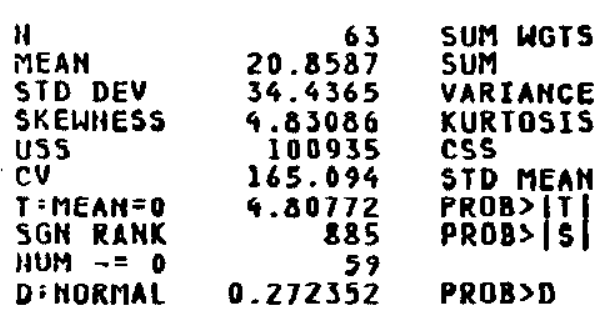

QUANTILES (DEF =4)

$\begin{array}{rc}13143 & 100 \% \text { MAX } \\ 1314.1 & 75 \% Q 3 \\ 1105.87 & 50 \% \text { 19ED } \\ 29.296 & 25 \% \text { Q1 } \\ 73524.2 & 0 \% \text { MIN } \\ 4.33859 & \text { RANGE } \\ 0.0001 & \text { MJ-Q1 } \\ 0.0001 & \text { MODE } \\ <0.01 & \end{array}$

DPST-83-209

$\begin{array}{rrr}245 & 99 \% & 245 \\ 26.7 & 95 \% & 69.5799 \\ 10.4 & 90 \% & 51.8999 \\ 5 & 10 \% & 2.4 \\ 0 & 5 \% & 0 \\ 245 & 1 \% & 0 \\ 21.7 & & \\ 0 & & \end{array}$

EXIREMES

\begin{tabular}{|c|c|c|}
\hline 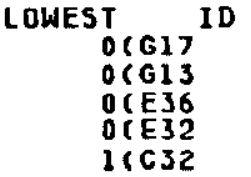 & ) & $\begin{array}{c}\text { HIGHEST ID } \\
60.5(E 3) \\
63.5(C 5) \\
7111(\mathrm{ADS} \\
93(G) \\
245(\mathrm{G})\end{array}$ \\
\hline
\end{tabular}


ALL GW DATA

UHIVARIATE

VARIABLE $=$ TOC

MOHENTS

II

MEAH

STD DEY

USS

T: MEAN $=0$

SGH RANK

$D:$ HORMAL
63 SUM WGTS

$\begin{aligned} 7.72381 & \text { SUH } \\ 28.7192 & \text { VARIANCE } \\ 7.24187 & \text { KURTOSIS } \\ 54895.4 & \text { CSS } \\ 371.827 & \text { STD MEAN } \\ 2.13467 & \text { PROB> T } \\ 315 & \text { PROB } \mid \text { S } \\ 35 & \end{aligned}$

$0.393987 \quad$ PROB>D

$\begin{array}{rc}483 & 100 \% \text { MAX } \\ 826.6 & 75 \% \text { Q3 } \\ 824.791 & 50 \% \text { MED } \\ 55.1153 & 25 \% \text { QI } \\ 51137 & 0 \% \text { MIN } \\ 3.61828 & \\ 0.0367488 & \text { RANGE } \\ 0.0001 & \text { Q Q Q1 } \\ <0.01 & \text { MODE }\end{array}$

$<0.01$
TABLE $\quad$ - 22

QUAHTILES (DEF $=4)$

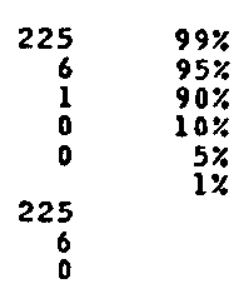

QUANT ILES ( DEF =4)

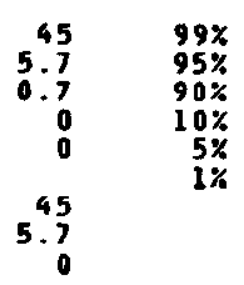

EXTREMES

225
20.32
12.02
0
0
0

LOWEST

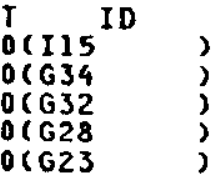

HIGHEST

$$
\begin{gathered}
16(I) \\
18(C 2) \\
20.9(C)) \\
45(67) \\
225(G 21
\end{gathered}
$$

GW DATA HITH J-SIGMA VALUES MISSIMG

UHIVARIATE

VARIABLE $=$ YOC

$\begin{array}{rc}62 & 100 \% \text { MAX } \\ 261.6 & 75 \% Q 3 \\ 51.9124 & 50 \% \text { MED } \\ 16.4598 & 25 \% 91 \\ 3166.66 & 0 \% \text { MIN } \\ 0.915039 & \\ 0.0001 & \text { RANGE } \\ 0.0001 & \text { QS-Q1 } \\ 50.01 & \text { MODE }\end{array}$

\section{MOMENTS}

NEAN

SID DEV

SY EWNESS

USS

CVIIEAN $=0$

SGII RAHK

D: HORMAL

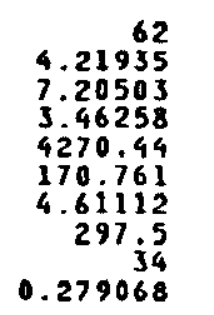

SUM WGTS

SUM

VARIANCE

XURTOSIS

CSS

5 ID MEAN

$\begin{aligned} & P R O B> \\ & P R O B>\end{aligned} \mid$

$P R O B>D$
EXTREMES

45
17.7
11.63
0
0
0

LOWEST

\begin{tabular}{|c|c|}
\hline $\begin{array}{l}\xi \\
\xi \\
\xi\end{array}$ & $\begin{array}{c}\text { HIGHEST ID } \\
12 \text { 1 } 1\left(\mathrm{CSO} 0^{\text {ID }}\right. \\
16(11) \\
18(C 2) \\
20.9(\mathrm{Cl}) \\
45(\mathrm{G})\end{array}$ \\
\hline
\end{tabular}

T)
O(I) 15
$0(G 34$
$0(G 32)$
$0(G 28$
$0(G 2)$

\section{mISSIHG VALUE \\ ic count/HOS \\ 1.59}


TABLE $D \cdot 23$

ALL GW DATA

\section{UNIVARIATE}

VARIABLE $=$ IIC

MOMENTS

$\begin{array}{lrl}\text { N } & 63 & \text { SUM WGTS } \\ \text { HEAN } & 13.1349 & \text { SUM } \\ \text { STD DEV } & 16.3409 & \text { VARIANCE } \\ \text { SKEWHESS } & 1.94032 & \text { KURTOSIS } \\ \text { USS } & 27424.6 & \text { CSS } \\ \text { CV } & 124.408 & \text { STD MEAN } \\ \text { T: MEAN=0 } & 6.38003 & \text { PROBS|T } \\ \text { SGH RAHK } & 770 & \text { PROB> S } \\ \text { HUH DE } & 55 & \\ \text { D:NORMAL } & 0.226862 & \text { PROB>D }\end{array}$

$\begin{array}{rl}63 & 100 \% \text { MAX } \\ 827.5 & 75 \% \text { Q3 } \\ 267.024 & 50 \% \text { MED } \\ 3.35109 & 25 \% \text { Q1 } \\ 16555.5 & 0 \% \text { HIN } \\ 2.05875 & \text { RANGE } \\ 0.0001 & \text { Q3 Q Q1 } \\ 0.0001 & \text { MODE } \\ <0.01 & \end{array}$

QUANTILES (DEF $=4$ )

$\begin{array}{rr}71.1 & 99 \% \\ 17 & 95 \% \\ 7 & 90 \% \\ 3 & 10 \% \\ 0 & 5 \% \\ 71.1 & 11 \% \\ 14 & \\ 0 & \end{array}$

EXTREMES

\begin{tabular}{|c|c|c|}
\hline $\begin{array}{l}\text { LOWEST ID } \\
\text { OCG } 16 \\
\text { OCGI) } \\
\text { OCGI3 } \\
\text { OCE } 36 \\
\text { OCESZ }\end{array}$ & $\begin{array}{l}\text { \{ } \\
\text { \} } \\
\text { \} }\end{array}$ & $\begin{array}{r}\text { HIGHEST } \\
48(67 \\
43.6(\mathrm{ES} \\
56.51 \mathrm{C3} \\
63.5(C 5 \\
71.1645\end{array}$ \\
\hline
\end{tabular}

GW DATA WITH 3-SIGMA VALUES MISSING

UHIVARIATE

VARIABLE $=$ I IC

MONENTS

\begin{tabular}{|c|c|c|}
\hline 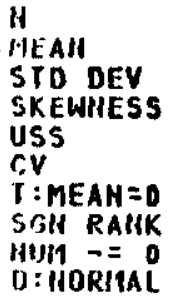 & $\begin{array}{r}61 \\
11.359 \\
13.2076 \\
1.80874 \\
18337.1 \\
116.274 \\
6.71788 \\
715.5 \\
0.213108\end{array}$ & $\begin{array}{l}\text { SUM WGTS } \\
\text { SUM } \\
\text { VARIANCE } \\
\text { KURIOSIS } \\
\text { CSS } \\
\text { STD MEAM } \\
\text { PROB> T } \\
\text { PROB P IS } \\
\text { PROB>D }\end{array}$ \\
\hline$\%$ couH & $\begin{array}{l}\text { UE } \\
\text { JNT } \\
\text { JBS }\end{array}$ & \\
\hline
\end{tabular}

QUANTILES (DEF =4)

$\begin{array}{rc}61 & 100 \% \text { MAX } \\ 692.9 & 75 \% \text { Q3 } \\ 174.441 & 50 \% \text { MED } \\ 2.82856 & 25 \% \text { Q1 } \\ 10466.5 & 0 \% \text { MIN } \\ 1.69106 & \\ 0.0001 & \text { RANGE } \\ 0.0001 & \text { Q3-Q1 } \\ <0.01 & \text { MODE }\end{array}$

EXTREMES

56.5
47.0999
35.5799
0
0
0

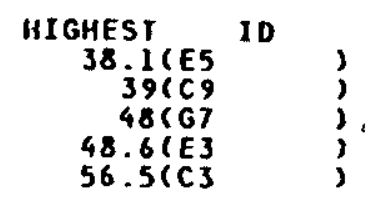


APPENDIX E

A SUMMARY OF THE CHEMICALLY ANOMALOUS WELLS

\section{(INCLUDING TABLES E1 AND E2)}


TABLE El. Five most extreme values: Including all wells outside of three standard deviations fron the mean of the calcuiated dictributions."

$\begin{array}{clllll}F & A-19 & C-9 & E-17 & E-3 & C-15 \\ \text { (PPM F) } & \underline{0.5} & 0.42 & 0.4 & 0.4 & 0.4\end{array}$

CI

$(\mathrm{ppm} \mathrm{Cl)}$

$\mathrm{NO}_{3}$

$\left(\mathrm{ppm} \mathrm{NO} \mathrm{NO}_{3}\right)$

$\mathrm{SO}_{4}$

(pprn $\mathrm{SO}_{4}$ )

$\mathrm{FO}_{4}$

$\left(\mathrm{pom} \mathrm{PO}_{4}\right)$

$\mathrm{H}_{2} \mathrm{SiO}_{3}$

(ppm si)

Na

(ppm Na)

E-I7

$c-5$

G-9

$c-3$

$A-5$

111

$\underline{24}$

$\underline{21}$

16.4

15.8

* These values are underlined. See Appendix $D$ for distributions.

** Detected only as phosphorus by plasma emission, presence of phosphate could not be contirmed. 
E. L. ALBENESIIUS

TABLE El. Cont'd

A Summary of Extreme Values. Including all ivolls outside of three standara deriations Eron the nean of the calculated distributions.

$\begin{array}{cccccc}K & I-13 & A-11 & E-17 & G-9 & A-5 \\ (\mathrm{ppm} \mathrm{K}) & \underline{110} & \underline{18.4} & 10.4 & 8.5 & 6.6\end{array}$

$\mathrm{Ca}$

G-23

$C-5$

$A-5$

E-17

$c-3$

(ppm Ca)

105

$\underline{102}$

92

56

44

Ba

I-13

I -17

$c-36$

$G-1$

$\varepsilon-36$

(ppm Ba)

21. 1 .

2.4

1.2

0.92

0.83

sr

$c-5$

A-5

$G-23$

$c-36$

I -13

(ppm Sr)

$\underline{0.61}$

$\underline{0.6}$

$\underline{0.51}$

0.5

0.48

Fe

G-2I

$G-7$

$c-19$

I - I

G-30

(ppm Fe)

113

61

13

0.8

0.7

Mg

G-7

$I-I 5$

C-19

I - I

$G-30$

(ppm Mg)

40

7.6

4. 3

3.51

3.4

DO

G-7

G-23

$E-30$

$c-9$

$I-5$

$\left(\operatorname{ppm} \mathrm{O}_{2}\right)$

1.5

1.7

2.0

2.4

2.5 
E. L. ALBENESTUS

TABLE El. Cont'd

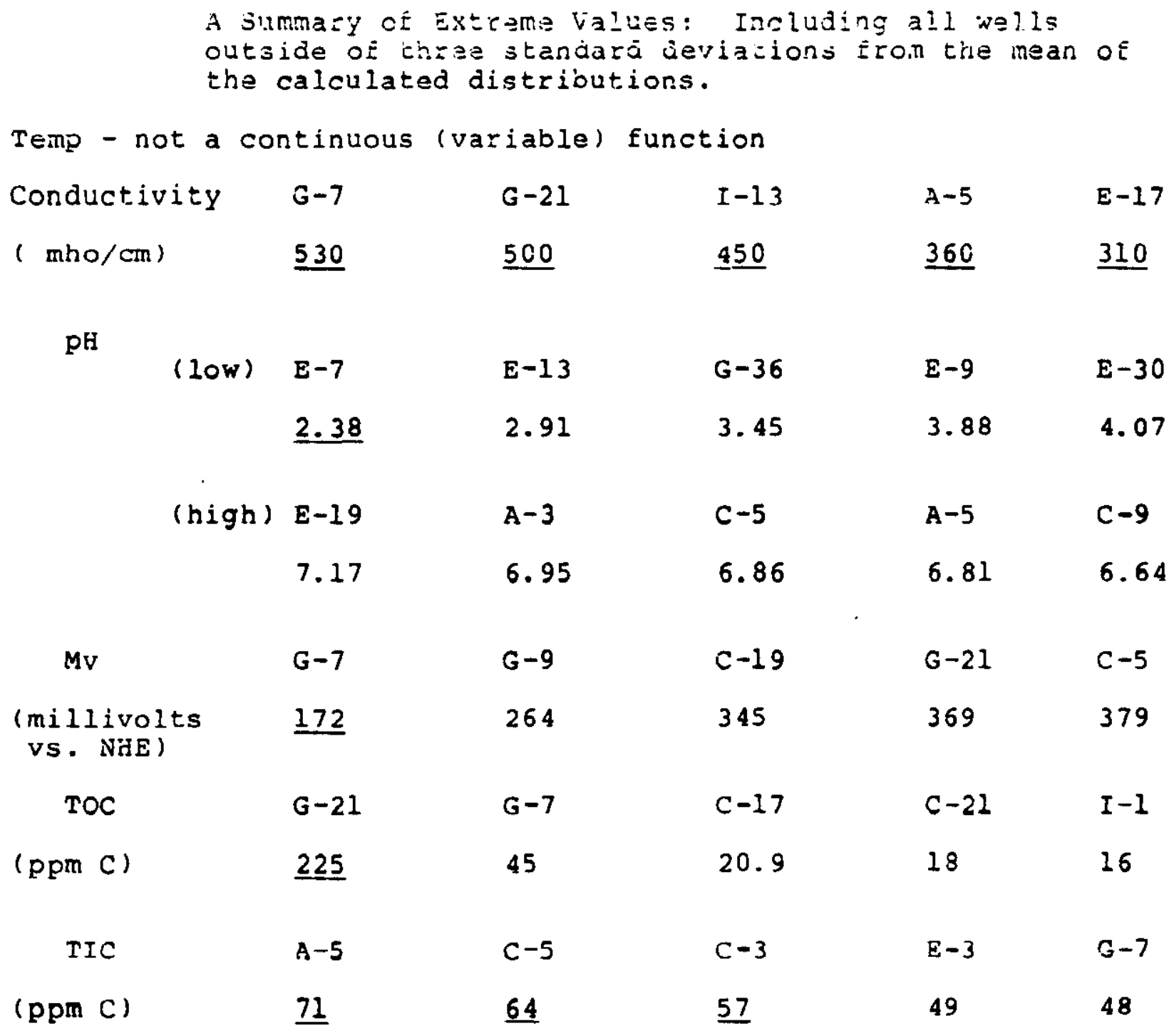




\begin{tabular}{|c|c|c|}
\hline WELL & $\begin{array}{l}\text { RADIONUCLIDES } \\
\text { PREDICTED }\end{array}$ & $\begin{array}{l}\text { RADIONUCLIDES } \\
\text { DETECTED }\end{array}$ \\
\hline$A-1$ & None & None $e^{b}$ \\
\hline $\begin{array}{l}A-3 \\
A-9\end{array}$ & $\begin{array}{l}\text { None } \\
\text { None }\end{array}$ & Sr-90, $\underset{\text { None }}{\mathrm{Pu}-238^{\mathrm{C}}}$ \\
\hline $\begin{array}{l}C-1 \\
C-3\end{array}$ & $\begin{array}{l}\text { None } \\
\text { Cs-137 }\end{array}$ & $\begin{array}{c}\text { Sr-90, } \mathrm{Pu}-238 / 239^{\circ} \\
\mathrm{Pu}-238\end{array}$ \\
\hline$c-13$ & None & None $e^{b}$ \\
\hline $\begin{array}{l}C-15 \\
C-17 \\
E-13 \\
E-17\end{array}$ & $\begin{array}{c}\text { None } \\
\text { None } \\
\text { None } \\
\mathrm{Pu}(\mathrm{IV}), \mathrm{Pu}(\mathrm{VI}) \\
\mathrm{Sr}-90, \mathrm{Cs}-137\end{array}$ & $\begin{array}{c}\mathrm{Pu}-238 / 239^{\mathrm{d}} \\
\text { None } \\
\text { None } \\
\mathrm{Cs}-137, \text { Co-60 }\end{array}$ \\
\hline$E-19$ & None & None \\
\hline $\begin{array}{l}G-17 \\
G-21\end{array}$ & $\begin{array}{c}\text { None } \\
\text { Pu(IV), Sr }-90 \\
\text { Cs }-137\end{array}$ & $\begin{array}{c}\text { None } e^{b} \\
\text { pu-238/239, Cs-137 } \\
\text { Sr-90 }\end{array}$ \\
\hline$G-34$ & None & None $e^{b}$ \\
\hline$I-1$ & None & None $e^{b}$ \\
\hline$I-5$ & None & None $e^{b}$ \\
\hline$I=7$ & None & None $e^{b}$ \\
\hline $\begin{array}{l}I-9 \\
I-13 \\
I-17\end{array}$ & $\begin{array}{c}\text { None } \\
\text { sr }-90, \text { Cs }-137 \\
\text { None }\end{array}$ & $\begin{array}{c}\mathrm{Pu}-238^{\mathrm{d}} \\
\mathrm{Pu}-238, \mathrm{Cs}-137 \\
\mathrm{Sr}-90 \\
\mathrm{Pu}-238 \\
\end{array}$ \\
\hline
\end{tabular}

a. Predictions are based on the 3-sigma criterion discussed in the text. See also Tables $E-1$ and $D-1$ and Appendix $E$.

b. Low-level alpha and gamma analyses, but $5 r-90$ was not measured.

c. Contamination apparently mobilized by complexants from equipment decontamination facility.

d. Contamination known to be related to solvent spill (see text, Operation's History). 
E. L. ALBENESIUS

APPENDIX $\mathrm{E}$

A SUMMARY OF THE CHEMICALLY

ANOMALOUS WELLS

(INCLUDING TABLES EI AND E2) 


\section{SUMMARY OF SUSPECT WELLS}

A-5 This veil is anomalously hich (rore than 3 s. 2 . in $\because$ mean of all wells) in calcium carbonate, silica anj sironci:n, probably all from natural sources. As described proviously, calcium mobilizes $S r-90$, and free carbonate $\left(1.8 \times 10^{-6}\right.$ is $\mathrm{CO}_{3}^{-}$ calculated for well A-5) could favor the formation of tise mobile hydroxycarbonate species with any available Pu(VI). The hydroxycarbonate of pu(VI) is favored over the insolubla Pu(VI) carbonate by $4 \times 10^{4}$. This places Well $A-5$ among the ten monitoring wells that are most susceptible to this complexation.

The most favorable oxidation states for plutonium in well $A-5$ appear to be $\mathrm{Pu}(V)$ and $\mathrm{Pu}(\mathrm{III})$. Pu(V) is favored by over
105 with respect to $\mathrm{Pu}(\mathrm{III})$, and $\mathrm{Pu}(\mathrm{VI})$ is about 10 more stable than $P u(I V)$ under the prevailing conditions $\left(\mathrm{pH}=6.8, \mathrm{E}_{\mathrm{H}}=0.5\right.$ volts $)$. Pu(V), which is not well complexed, is about $10^{7}$ times more stable than the free Pu(VI), but Pu(VI) hydroxycarbonate is also favored over $\mathrm{PuO}_{2}{ }^{2}+$ by $8 \times 1011$. The net increase in solubility of plutonium due to the hydroxycarbonate complex is nearly $10^{5}$ with respect to $\mathrm{Pu}(\mathrm{V})$, which is the most thermodynamically stable form of free plutonium in this system.

In a soil-water equilibrium, the dissolution of plutonium is reduced by a factor that can be related to the operating distribution coefficient (usually $10^{3}$ to $10^{4}$ ). The predicted concentration of plutonium for a homogeneous system that is in equilibrium with solid plutonium oxide, along with water of the same composition as that in well $A-5$, and typical burial ground soil, is on the order of the solubility of plutonium in that water. This is because, as descrioed above, most of the soluble plutonium would be present as the non-exchangeable (anionic) hydroxycarbonate complex.

Well A-5 is also among the top five in sulfate (15.8 ppm), potassium $(6.6 \mathrm{ppm}), \mathrm{pH}(6.81)$, and magnesium $(3.4 \mathrm{ppm})$ and is a "suspect" for its high conductivity $(360 \mu \mathrm{mho} / \mathrm{cm})$. These observations indicate the influence of a nearby trench and clearly mark $A-5$ as a well with the potential of being contaminated by fission product activity from that trench. However, radiochemical data on well A-5 show low values $<<60$ $\mathrm{pCi} / \mathrm{L}$ since 1976) for non-volatile beta-gamma activity, with a negative year-to-year slope $(-5.8 \mathrm{pCi} / \mathrm{L}$ since 1976). This well is probably stabilizing, and it is unlikely to show a significant increase in fission products in the near future. The alpha activity in this well is 6 th highest of all burial 
E. L. ALBENESIUS -105- DPST-83-209

ground wells $(4 \mathrm{pCi} / \mathrm{L})$ and is increasing slightly, at the race OE $0.24 \mathrm{pCi} / \mathrm{L}-\mathrm{Y}$ ear.

A low-level pulse height analysis, a gana scan, an Sr-90 analysis should all be performed on well A-j to determine the source of the activity. Regliar monitoring of this well should continue along with the other "suspect" wells.

A-11 Nell A-11 is mentioned here because it contains 13.4 pom of potassium. This concentration is sufficiently large to exclude well A-11 from a modified distribution of potassium values for all wells. The modified distribution was obtained, as described previously, by first excluding all wells that deviated by three standard deviations or more from the mean of the best* potassium values for all wells.

Potassium, being poorly hydrated and about the same size as cesium, competes relatively well with Cesium-137 for ion exchange sites on the soil. In situations of slow kinetics (or non-equilibrium) Cesium-137 might be moved at very low concentrations and could reach the groundwater at trace levels. Ultra-trace analysis of radioisotopes has not been performed yet, but the gross alpha and non-volatile beta-gamma measurements indicate no activity above background.

A-19 Well A-19 contains more fluoride than any other monitoring well $(0.5 \mathrm{ppm})$. As described in the section on fluoride, even this small amount may be able to complex Plutonium (VI). The monitoring results of this well are also negative for gross alpha and non-volatile beta-gamma. Low-level analysis has not been performed.

The anionic fluoride complex $\left(\mathrm{PuO}_{2} \overline{\mathrm{F}}_{3}{ }^{-}\right)$is favored in this well by a factor of 1100 over the free plutonium (VI) cation. However, the hydroxycarbonate complex may be more important since it is favored in this well by roughly $10^{10}$ over the free Plutonium (VI) cation. Plutonium(V) is the most stable species at the $\mathrm{pH}$ and reduction potential of Well $\mathrm{A}-19$, but 108 of Pu(III) would also be expected. The free Pu(VI) concentration would be on the order of one part per million of the dissolved Pu(V). Complexation of Pu(VI) mobilizes some plutonium, but soil adsorption and hydrolysis of Pu(III) have the opposite effect. Therefore, only traces of Pu(VI) complexes would be likely to remain in solution.

Best values denote averages of all available data for each individual well. 
A-36 This well is considered a radionuclide migraicion "suspect" because 1.8 pom of phosphate $705 \geq$ detzotza (This concentration is also more than thred ilangare deviations higher than tre mean of the noui Phosphate at this concentration complexas $P u(I V)$ effectively, the ratip of the tetra-anion complex to free $P_{u}$ (IV) being $1.6 \times 10^{19}$ at equilibrium. $\mathrm{Pu}(\mathrm{IV})$ is not stable i.s this well with respect to Pu(III), except at very small concentration ratios ( 1 part per million). Govever, the oxidized plutonium states are only slightiy íavored over Pu(IV) and Pu(III) in this well, and phosphate would shizt the equilibrium toward Pu(IV).

If this water were at a source of plutonium, the complexation reaction would be limited by the phosphate concentration. During transport, the plutonium concentration would diminish through dilution, but soil adsorption would have little impact on such a strong anionic complex.

Therefore, well A-36 should be analyzed carefully for traces of plutonium.

C-3 This well was high in silica, sodium, and inorganic carbon. It was also among the highest in sulfate and calcium. of these, the most significant are the high sodium and inorganic carbon, both of which exceeded the mean (of the modified distribution) by over three standard deriations. The sodium, and probably most of the carbonate, came from a man-made source (trench).

The sodium concentration of $31.9 \mathrm{ppm}$ could be enough to enable a detectable quantity of $\mathrm{cs}-137$ to reach the groundwater under non-equilibrium conditions. Howerer, the low-level count performed on a water sample from $\mathrm{C}-3$ indicates that this has not happened so far. Since equilibrium strictly favors the irreversible retention of cesium by the soil column, very little, if any, Cesium-137 would be expected to emerge later. Traces of $\mathrm{Sr}-90$ could appear later, however, due to gradual elution by sodium and calcium. Low-level analysis detected no Strontium-90 or Cesium-137 in well c-3 ( $<6 \mathrm{pci} / \mathrm{L}$ and $<8 \mathrm{pCi} / \mathrm{L}$ respectively).

Traces of Pu-238 ( $2 \pm 1 \mathrm{pCi})$ were detected in Nell C-3, but no Pu-239 was detectable: This contamination may be due to the remaining traces of contamination from an eqidipment decontamination station that was once located in the northwest corner of the burial ground. Although the exact location of the station is not known, it is believed to have been just north of grid Well A-3 (see Section $V$, Burial Ground His tory). 
E. L. ALBENESIUS

The high pa of well C-3 (6.14) Eavors the oxidized states

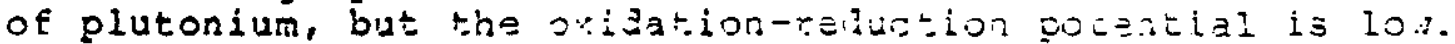

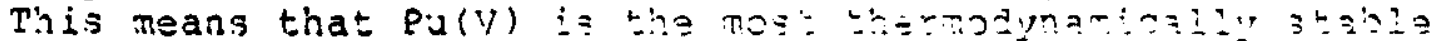
state Eor plutonium. The calculated equilioridm constant Eo: hydroxycarbonate complexation of $P u(V I)$ is about 1010 , but so is the ratio of $\mathrm{Pu}(V) / \mathrm{Pu}(V I)$. Plutonium would, therefore, move roughly as fast as the free Pu( $V)$ in this system.

C-5 Total inorganic carbon, calcium, and strontium vere high in Well C-5. Sulfate and silica also exceeded the criteria for suspecting chemical contamination. In adaition, the pH of Well $c-5$ was the third highest of all wells.

These values lead one to expect $S r-90$ to appear in Nell $\mathrm{C}-5$. Unfortunately, $\mathrm{C}-5$ has not been analyzed for trace levels of this radionuclide. Traces of other cationic radionuclides could be mobilized by the high calcium concentration, but the most important variable is probably the large amount of free carbonate, which could theoretically mobilize plutonium (VI). The likelihood of hydroxycarbonate plutonium complexation is about two orders of magnitude lower than for well A-5 because the redox potential of well $\mathrm{C}-5$ is about $120 \mathrm{mv}$ lower.

C-9 Monitoring Well $\mathrm{C}-9$ is abnormally high in sodium for the lithology of the SRP Burial Ground, indicating that it, too, contains chemical contamination from the waste trenches. This concentration $\left(1.7 \times 10^{-3} \mathrm{M}\right)$ is too low to significantly enhance the overall mobility of Cs-137 or even $\mathrm{Sr}-90$ by the soil (see Sodium). However, this concentration could shift the surface potential of the soil positively enough to allow an extremely low concentration of $\mathrm{Cs}-137$ to reach the groundwater. This scenario is not highly probable, but doas have credibility, since similar effects seem to have occurred in wells $E-17, G-21$ and $I-13$. Well $C-5$ should therefore be analyzed carefully for traces of $\mathrm{Cs}-137$ and $s r-90$. Well $\mathrm{C}-9$ is also more alkaline ( $\mathrm{pH} 6.64)$ than all but four other wells and it contained $0.42 \mathrm{ppm}$ of fluoride. Pu (VI) could therefore be mobilized at very low concentrations around this well.

C-19 Well c-19 contains 13 ppm of iron, presumably as Fe(II) rather than complexed Fe(III). The oxidation potential of this well was also low $(0.345 \mathrm{~V}$ us. SHE) as was the dissolved oxygen content $\left(2.7 \mathrm{ppm}\right.$ at $\left.22^{\circ} \mathrm{C}\right)$. Interestingly, the organic carbon content was below the detection limit (about 1 pom in most determinations).

This well should be considered a candidate for low-level analysis, and is likely to contain traces of $5 r-90$ and Cs -137 . 
C-23 This well contains 1.6 ppm of phoshase, which could indicate a potential source oz pu (Iij). Again, calz'stions (see Phosphate), protict a linitad onzon:iai Eor tis

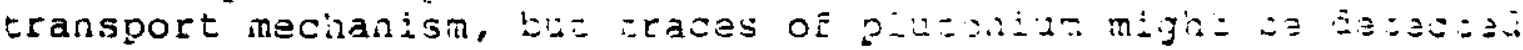
in this monitoring well. (Sae well $\mathrm{A}-36$ )

E-5 High concentrations of phosphorus (15.1 ppm) were detected in one sample froin this well in 1981. Subseguent analysis of this sample coild detact no orthophosphate. Samples obtained in 1982 have shown no decectable phosphoris of any kind. Potential explanations include analytical erro: (plasma emission), but TBP-solvent contamination on the soil at the height of the water table (at that time) is also conceivable. Variations of this kind have been seen before in locations around the 1971 solvent spill (REF. DPST-77-495). activity.

Weli E-5 should be analyzed for traces of plutonium

E-7 The $\mathrm{pH}$ in this well was exceptionally low $(\mathrm{pH}=2.38)$. However, none of the other paraneters, including conductivity, were significantly deviant. As expected, the total carbonate concentration in this well was lower than normal.

In low pH systems of this kind, the bulk migration rate of Ru-106, SI-90, and Cs-137 are greatly enhanced. (see pri) This well should therefore be suspected of containing traces of these radionuclides. The levels of Sr-90 contamination would be expected to be higher than those of other Eission products if $\mathrm{pH}$ does affect radionuclide transport around this well.

E-17 This well contains elevated concentrations of sodiun ( 30 opm), calcium ( $56 \mathrm{ppm}$ ), potassium (10 ppm), and sulzate (III ppm). Like Well E-5, it also appeared to contain a phosphorus compound (13.7 ppm $P$ ) in 1981. The pH was relatively high (6.54), fluoride was present $(0.4 \mathrm{ppm})$, and the conductivity was fifth highest of all wells $(310$ mmo/cm).

This well has a history of non-volatile beta-gamma contamination and it is in the vicinity of the TBP/ultrasene solvent spill that occurred in 1971 (see Operation's History). Both Cs -137 and Co-60 have been detected by low-level gamma spectrometry. No $\mathbf{S r}-90$ or plutonium isotopes were detected, but continued low-level monitoring should be perkormed.

G-7 This well was anomolous in more chemical parameters tha? any other well. The oxidation-reduction potential was the lowest ( 0.172 V vs. S.H.E.), conductivity the highest $(530$ $\mu m h o / \mathrm{cm})$, magnesium the highest (39.9 opm), and iron the 
E. L. ALBENĖSIUS

second highest $(60.6 \mathrm{ppin})$ of all vel1s. Total organic carbon, sodium and chloride nere ali statistically aconzmal, and the

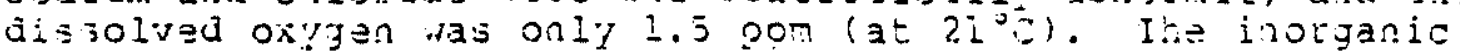

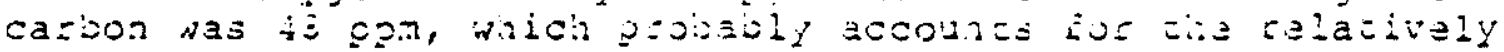
high pH $(6.48)$.

Careful analysis of this well would probably detect Cs-137, Sr -90 and several ocher fission products. The extremely high concentration of dissolved organic sacion ( 45 ppmi) that was detected in this well means that plito.j. in may also be present as an organic complex of $P U$ (IV). Aside froin a detailed radiochemical analysis, this well is a prine candidate for a complete organic analysis.

G-9 Well G-9 is statistically high in sulfate ( $21 \mathrm{ppm})$. It also is slightly high in magnesium, potassium, and sodium. The presence of organic carbon and the low oxidation-reduction potential $(0.264 \mathrm{~V})$ could be signs of organic complexation strength. However, the conductivity of this well $(140 \mu \mathrm{mho} / \mathrm{cm})$ is only slightly higher than the average.

This well probably does not contain Sr-90 or Cs -137 at measurable levels. Plutonium could be present, but only in the form of an organic complex of $P_{1}$ (IV).

G-21 This well has long been identified as a "bad actor" in the 543-G Burial Ground. It has a history of tritium contamination, plutonium contamination ( $P J-238 / 239)$, and non-volatile beta-gamma contamination (see Tables Bl-82). $3 r-90$ has been detected at $1600 \mathrm{pCi} / \mathrm{L}$ in NelI G-2l.

The well water is reduced relative to the surrounding systam (dissolved oxygen $=2.8 \mathrm{ppm}, E_{h}=0.369 \mathrm{~V}$ ). The pH i.s $a$ moderate 5.03 but the iron concentration and dissolved organis carbon were the highest detected in the burial groung ( $?$ ? = $112.8 \mathrm{ppm}, \mathrm{TOC}=225 \mathrm{ppm})$. Chloride was also relatively high at $33 \mathrm{ppm}$.

The chemical parameter most responsible for the strontium migration here may be the large amount of iron in solution. The plutonium is probably in the form of organic complexes of Pu (IV).

Additional low-level analyses of this well should be performed. The source of the contamination and the operating " $K_{d}$ " for the radionuclides in this system should be identified through coring studies. A complete analysis of tho organics in the system is also highly desirable. 


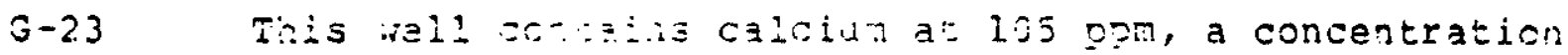

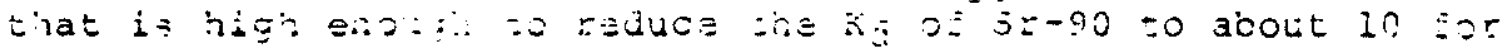

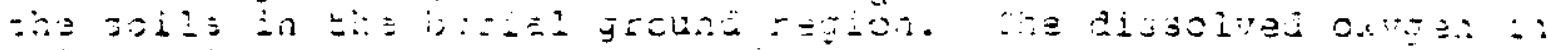

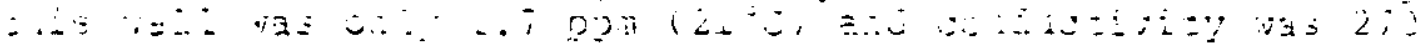

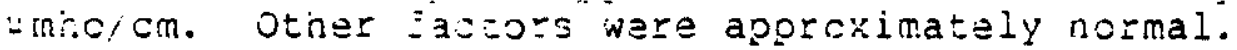

Sa.roiaj cE vator irom Mall s-23 siculd be subnitted for loiv-levai analysis, эsฐacialiy ji-90.

i-13 Aishough me scurces, vell I-13 has a history of alpha and beta-ganna concamination (see Table Bl). Fowever, given the high levelo of chemical contamination that were measured, it is not surprising that $\mathrm{Cs}-137(10 \mathrm{pCi} / \mathrm{L}), \mathrm{Sr}-90(19 \mathrm{pCi} / \mathrm{L})$ and even trace levels of plutonium $(2 \pm 1 \mathrm{pCi} / \mathrm{L}$ of $\mathrm{Pu}-238)$ were identified in that well. WeII $I-13$ is also one of the wells that were contaminated with TBP/uitrasene extraction solvent in 1971.

The conductivity of water samples from well I-13 was 450 $\mu \mathrm{mho} / \mathrm{cm})$. Abnormally high levels of three cations were measured, including potassium ( 110 pom), sodium (40 ppm) and barilim $(21 \mathrm{ppm})$. I-13 was one of only three wells that exceeded 1 ppm of barium, and it contained by far the most. The next highest was $2.4 \mathrm{ppm}$, detected in Nel1 I-17. Chloride was $152 \mathrm{ppm}$ in I-13, also the highest of any well.

This well should be analyzed in the iuture to verily the apparent downward trend in radionuclide contamination levels. ddaitional chemical monitoring should be employed to decect any correlation between changes in activity and the chemical

contamination level. Trace level organic analysis siould also be attempted, to test the hypothesis that piaconium contamination has come about solely due to the solven soil? which occurred in 1971.

I-15 This well was statistically abnormal in chloride ( $35 \mathrm{pgm})$. Nitrate ( $28 \mathrm{ppm})$, magnesium ( $7.60 \mathrm{ppm}$ ) and socium (19 ppm) wer@ also slightly high, but the overall conductivity was actually lower than average due to the lack of calcium carbonate. this well.

Enhanced radionuclide transport is not predicted around

I-17 This well is anomalous for its barium content $(2.4$ pom). The magnesium to calcium concentration ratio is slightly high, but it is uncertain whether this indicates natural of "rasto" calcium. Several other apparently normal velis were also slightly higher than average in magnesiun/oaloium. Other parameters were approximately normal. Radioactivity woula not 
be expected in Well I-17, bit the presance of barium 12.4 egn) has not been aderlateiy arpiained, and thare oould be

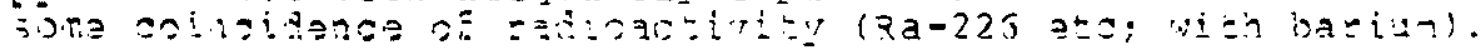

Approximately $2 \mathrm{pCi} / \mathrm{L}$ of $\mathrm{Pu}-233$ were detected in this well (Jan. 1981). Additional measurements are needed to confirm this finding, which could be caused by organic complexation. Even $1.6 \mathrm{ppm}$ (the TOC in I-17) of a complexing agent could mobilize measurable concentrations of Pu (IV). Plthough it was not one of the wells that were affected originally, well I-17 may have been contaminated slightly by the solvent spill that occurred in 1971 (see Operation's itistory). 
E. L. ALBENESTIUS -113-

DPST $-83-209$

2-2 Exsept Eor having the second highest $2 \mathrm{~d}$ (6.95) of all monitoring weils, iell A-3 was unr inarkaile in its chemistry,

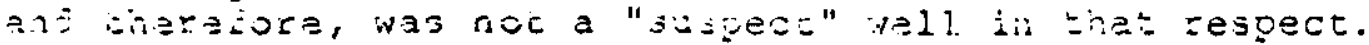

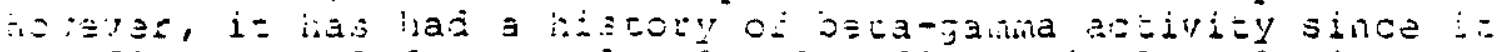
was first sampled, so a lon-level radiochemical analys is was performed. Alpha activity (pu-238) and fission products $(\mathrm{Cs}-137$ and $\mathrm{s} r-90)$ were detected.

The source of the contamination probably lies in the fact that an efuipment decontamination station once operated nearby. The pradicted flow path of complexed macerial is from the old station, through $A-3$, through wells $C-1$ and $C-3$ and then to the south and west (see figure 5). The trend of data over the past five years on well $A-3$ is toward lower and lower non-volatile beta-gamma activities (with a 5-year average slope of $-138.5 \mathrm{p}(\mathrm{i} / \mathrm{L}-\mathrm{yr}$ ). Present levels of activity are less than $70 \mathrm{pCi} / \mathrm{L}$ non-volatile beta-gamna so $\mathrm{pCi} / \mathrm{L}$ of $\mathrm{Sr}-90$ and $11 \mathrm{pCi} / \mathrm{L}$ of $\mathrm{Pu}-238$. Since the decontamination station is no longer operating, this downward trend is expected to continue.

C-3 The only man made activity that was detectable in this well was a trace of plutonium $(2 \pm 1 \mathrm{pCi} / \mathrm{L}$ of Pu-238). Since no Pu-239 was detected, precise measurement of the $238 / 239$ ratio could not be used to confirm or deny the theory that a common source was responsible for the contamination in wells $C-1, C-3$, and $A-3$ (see operations History).

C-15 Tinis well does not show any unusual chemical characteristics other than the presance of $0.4 \mathrm{ppm}$ of Eluoride. As described previously (see Fluoride) this concentration could mobilize small amounts of Fu(VI).

iell $\mathbf{C}-15$ has a history of alpia contanination (sea. radiochenical data, Table 31), and coti ₹u-238 and Pu-239 have been identified in that well. Althougn $i=$ is possible that flouride contributed to the mobility of the plutonium, the most likely transport mechanism is organic complexation, probably in the form of TBP and its degradation products. These complexes could have come from the solvent burning operations which took place in the trenches near there. An even more likely source, however, is the solvent spill, in 1971, which allowed several hundred gallons of solvent to reach the water table (see Operations listory).

I-9 A trace of plutonium was detected in this well $(2 \pm 1 \mathrm{pCi} / \mathrm{L}$ of $\mathrm{p} u-238)$. The source ras probably T.BP-kerosene extraction solvent that was spillea in 1571 (a ee operations tistory). 


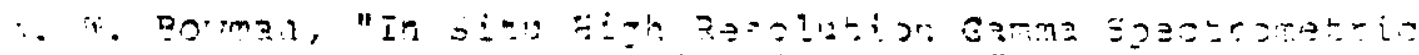
jLevey oz ouriaj Ground vonicoring rells", USDOE Report [.P-1598, E. I. du Pont de Nemours and Company, Savanna'n River Laboratory, Aiken, SC, (September, 1981).

2. J. N. Eanimore and R. I. Hooker, "The Assessment of Solid Liv-Level raste vanagement at the Savannah River plant", UsdoE Report DPST-77-300, E. I. du Pont de viemours and Company, Savannah River Laboratory, Aiken, SC (August, 1977).

3. D. W. Tharin. "Burning of Radioactive Process Solvent." USDOE Report DP-942, E. I. du Pont de ivemours and Company, Savannah River Laboratory, Aiken, SC (1965).

4. Final Environmental Impact Statement, Waste Management Operations, Savannah River Plant. USERDA Report ERDA-1537 (September, 1977).

5. J. W. Fenimore, memorandum to E. L. Albenesius, E. I. du Pont de iemours and Company, Savannah River Laboratory, Aiken, SC, DPST-77-495, (NOV. 1, 1977).

5. J. w. Fenimore, "Radioniclides in 643-G Groundwater 1973-1976", Temorandum to E. L. Albenesius, E. I. du Pont de iemours and Company, Savannah River Laboratory, diken, SC, (jovember 23,1977).

7. J. w. Fenimore, "Annual summary of Burial Ground Grid well Assays - 1977", memorandum to E. L. Albenesius, E. I. du Pont de Nerrours anä Compary, Sayannai River Laboratory, Aik DPST-73-425, (JUII 11, 1973).

8. J. iv. Eenimore, "The Buria?. Ground as a Containment system: 25 Years of Subsurface Monitoring at the Savannat. River Plant Facility", E. I. du Pont de Jemours and Company, Savannah River Laboratory, Aiken, SC, DPST-82-725, (June 30, 1982).

9. R. S. Czyscinski and A. J. Vieiss. "Evaluation of Isotope Migration - Land Burial: water Chemistry at Cominercially Operated Low Level Radioactive Waste Disposal Sites: Status Report October 1979-Septemiver 1980." Us Nuclear iNUREG/CR-1862 Regulatory Commission Report, Brookhaven ivational Laboratory, upton, NY (January, 1981 ).

10. R. A. Dana, et. 21. "Generzl Inrestigation of Radionuclide Retention In iligration Patiriays at Lie iest Valley, New York now-lavel Burial Site: Final Report." New York state Geological survey/State Wusedm, UUREG/CR-156j (October, I980). 


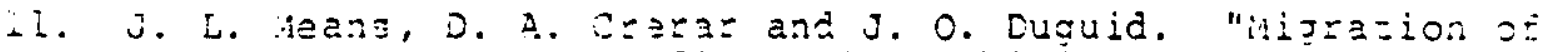

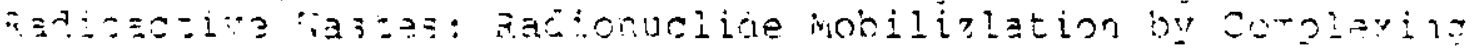

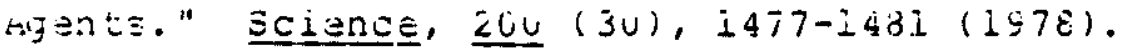

12. J. L. Neans and D. W. Hastings. "Organs study: Guazterly Technical Progress Report to ONNI for the Period Jan I., 1980 through March 31, 1980." Battelle, Columbus Laboratories, Columbus, Oi (1980).

13. in. E. Prolit. "Adsorption of Radioactive wastes by Eavannah River Plant Soil." Soil Science, 86, 13-17 (1958).

R. H. Raney, USAEC Report CF-59-12-95, Dec. 30, 1959.

14. D. J. Silvera. "The Potential Influence of organic Compounds on the Transport of Radionuclides from A Geologic Repository." Pacific Norwest Laboratory, Richland, WA., USDOE Report PNL-3414 (March, 1981).

15. A. J. Weiss and P. Colombo. "Evaluation of Isotope Migration-Land Burial: iater Chemistry at Commercially Operated Low-Lavel Radioactive Waste Disposal Sites: Status Report Through sectemior 30, 1979." US Nuclear Reglilatory Commission Report WUKEG/CR-1289, Brookhaven National Laboratory, Upton, iY (Jan., 1980).

15. E. P. Spalding. "Adsorption of Radiostrontium by Soil Treatea with Alxali detal äydroxides." Soil Sci. Am. J., 44, 703-70s $(1980)$.

17. J. H. horton and J. C. Corey, "Storing Solid Radioactive hastes at the Savannah River Plant", USDOE Report DP-1366, E. I. du Font de Nemours enc Company, Savannah River Laboratory, tiken, SC (June, 1976).

18. R. F. Anderson, M. P. Bacon and P. G. Brewer. "Radionuclides in Mono Lake, California." Science, 216, 516 (1982).

19. J. S. Wahlberg and M. J. Fishman "Adsorption of Cesium on Clay Minerals". Geological Survey Bulletin 1140-A, (1962).

20. E. A. Bondietti and C. N. Francis. "Chemistry of TC-99 and $\mathrm{Np}-237$ in Contact with Jnweathered Igneous Rocks."

pp. 417-413, of "Scientific Basis for Nuclear Waste Management, volume I." G. J. McCarthy, Ed., Plenum Press, New York, NY (1979). 
21. J. C. Morris and w. Stum. "Redox Equilibria and Measurements z: Fotentials in the Pguatic Environment."

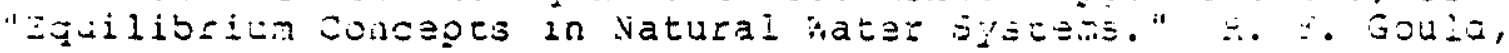
Ed., American Chemical Society, Wasington, DC (1967).

22. E. L. Nilhite. Hemorandum to E. L. Albenesius "vovenent of Organicaliy Bound Plutonium in Soil" E. I. du Pont de vemours and Company, Javannah River Laboratory, Aiken, SC, DPST-75-377 $(1975)$.

23. E. i. Albenesius, letter to w. J. Mottel, Manager, Savannah River Plant, March $15,1977$.

24. Environmental Protection Agency. "National Interim Primary Drinking water kegulations," EPA-570/9-76-003, EPA office of Water supply, Washington, DC 20460 (1976).

25. J. w. Fenimore, personal communication, 1982.

26. W. W. Bowman, "Preliminary Borehole Results", memorandum to A. L. Boni, E. I. du Pont de Nemours and Company, Savannan River Laboratory, Aiken, SC (May 14, 1980).

27. "jtrontium-90 Determination" E. I. du Pont de Nemours and Company, Savannah Rivez Laboratory, Aiken, SC. DPSOL 27i-272 $($ i 975$)$.

28. L. V. Benson and L. S. Teague. "A Tabulation of Thermodynamic Data for Chemical Reactions Involving 58 Elements Common to Radioactive Waste Package Systems." USDOE Report LBL-11448, Lanrence Barkeley Laboratory, Berkeley, CA, (August, 1980).

29. G. A. Parks. "Aqueous surface Chemistry of Oxides and Complex oxide i'inerals." p. 121-150 of "Equilibrium Doncepts in iatural ivater systems." R. F. Gould, Ed., American Chemical Society, washington, DC (1967).

30. S. J. Fritz and R. W. Rcot, unpublished data, E. I. du Pont de Nemours and Company, Savannah River Laboratory, Aiken, SC $(1980)$.

31. D. Langmuir. "Uranium Solution-Mineral Equilibria at Lom Temperatures with Applications to Sedimentary ore Deposits." The Pennsylvania State University, University Park, NTIS \# GJO-1659-3 (December, 1977). 
32. Letimer, $\mathcal{K}$. M. "The oxidation States of the Elerents and Theis Potentials in Aquesus solutions, 2nd ei.," sn. 7, p. 9:-105, Prentice-iali Inc., Englewcod Clifis, N. J. (i952).

33. I. Barin, O. Knacke, and 0 . Kubachewski. "Thezmodynamic Properties of Inorganic Substances." jpringer-Verlag m.b.h. Dusseldorf, Germany (1977).

34. J. M. Cleveland. "The Chemistry of Plutonium." American Nuclear Society, LaGrange Park, IL (1979).

35. G. H. Coleman. "The Radiochemistry of Plutonium." Lawrence Radiation Laboratory, Livermore, CA , USAEC Report NAS-NS 3058 (Seotember 1, 1965).

36. 3. J. Fritz and G. H. Schenk. "Quantitative Analytical Chemistry." 3rd Ed. Allyn and Bacon, Inc., Boston, MA (1974).

37. E. A. Bondietti and J, R. Trabalka, "Evidence for Plutonium /V/ in an Alkaline, Freshwater Pond", Radiochem. Radioanal. Letters, 42, (3), 169-176, (1980).

33. J. M. Cleveland and T. F. Rees. "Characterization of Plutonium in Maxey Flats Radioactive Trench Leachates." Science, 212, $1506(1981)$.

39. E. i. wilhite. "Chemical speciation of Plutonium in the Radioactive waste Burial Ground at the Savannah River Plant." USERLA Report DP-1511, E. I. du Pont de Nemours and Co., Savannain River Laboratory, Aiken, SC (August, 1978).

40. "Bedroci fiaste Storage - Technical Progress Report - September 1972 - June 1972." Compiled by I. N. Marine, E. I. Ju pont de Nemours and Company, Savannah River Lacoratory, Aik an, SC, DPST-73-122-1 (1973).

41. D. R. Johnson and E. L. Wilhite. "Migration of Transuranic Nuclides in Earthen Burial Trenches at the Savannah River Plant." Presented at a Symposium on "Migration of Transiranic Nuclides in the Environment." National Avs Meeting, San Francisco, CA, USDOE Report DP-MS-79-20 (1979).

42. D. A. Skoog and D. M. West. "Fundamentals of Analytical Chemistry, 2nd Ed." Holt, Rinehart and finston, Inc, New York, NY (1969). 
43. D. J. Gjerde. "Ion Chromatography." Pr.D. Thesis, Io:a State linversity, Ames, Iowa (1980).

44. R. H. Raney, USAEC Report CF-59-12-95, Dec. 30, 1959.

45. w. Stober. "Formation of Silicic Acid on Aqueous Suspensions of Different silica Modifications." pp. 161-182, of "Equilibrium Concepts in Natural Water Systems." R. F. Gould, Ed., American Chemical Society, Washington, DC (1967).

46. W. E. Prout "Adsorption of Fission Products by Savannah River Plant Soil." USAEC Report DP-394, E. I. du Pont de Nemours and Company, Savannah River Laboratory, Aiken, SC (1959).

47. J. S. Wahlberg, J. H. Baker, R. N. Vernon and R. S. Dewar. "Exchange Adsorption of Strontium on Clay Minerals." Geological Survey Bull. 1140-C, (1965).

42. J. L. Means, D. A. Crerar, and J. O. Duguid, "Chemical Viechanisms of Co-60 Transport in Groundwarter from Intermediate Level Liquid Waste Trench 7: Progress Report for Period Ending June 30, 1975." USERDA Report OR NL/TM-5348, Oak Ridge National. Laboratory, Oak Ridge, TN (1975).

49. J. P. Ryan, DPST-83-272, to be issued.

50. C. M. King and R. W. Root, Jr. "Radionuclide Migration Model for Buried Waste at the Savannah River Plant." p. 155 in Waste Management ' 82 , Vol. 2. R. G. Post, ed. Univorsity of Arizona, Tucson, 1982.

JER : S'Ke

Disc $1-4$ 